\title{
Water-Use Analysis Program for the Neshaminy Creek Basin, Bucks and Montgomery Counties, Pennsylvania
}

U.S. GEOLOGICAL SURVEY

Water-Resources Investigations Report 96-4127

Prepared in cooperation with the

DELAWARE RIVER BASIN COMMISSION

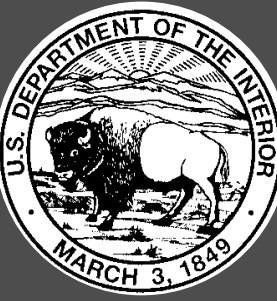




\section{Water-Use Analysis Program for the Neshaminy Creek Basin, Bucks and Montgomery Counties, Pennsylvania}

By CURTIS L. SCHREFFLER

\section{U.S. GEOLOGICAL SURVEY}

Water-Resources Investigations Report 96-4127

Prepared in cooperation with the DELAWARE RIVER BASIN COMMISSION 


\section{U.S. DEPARTMENT OF THE INTERIOR \\ BRUCE BABBITT, Secretary}

U.S. GEOLOGICAL SURVEY

Gordon P. Eaton, Director

The use of firm, trade, and brand names in this report is for identification purposes

only and does not constitute endorsement by the U.S. Geological Survey.

For additional information write to:

District Chief

U.S. Geological Survey

840 Market Street

Lemoyne, Pennsylvania 17043-1586
Copies of this report can be purchased from:

U.S. Geological Survey

Branch of Information Services

Box 25286

Denver, CO 80225-0286 


\section{CONTENTS}

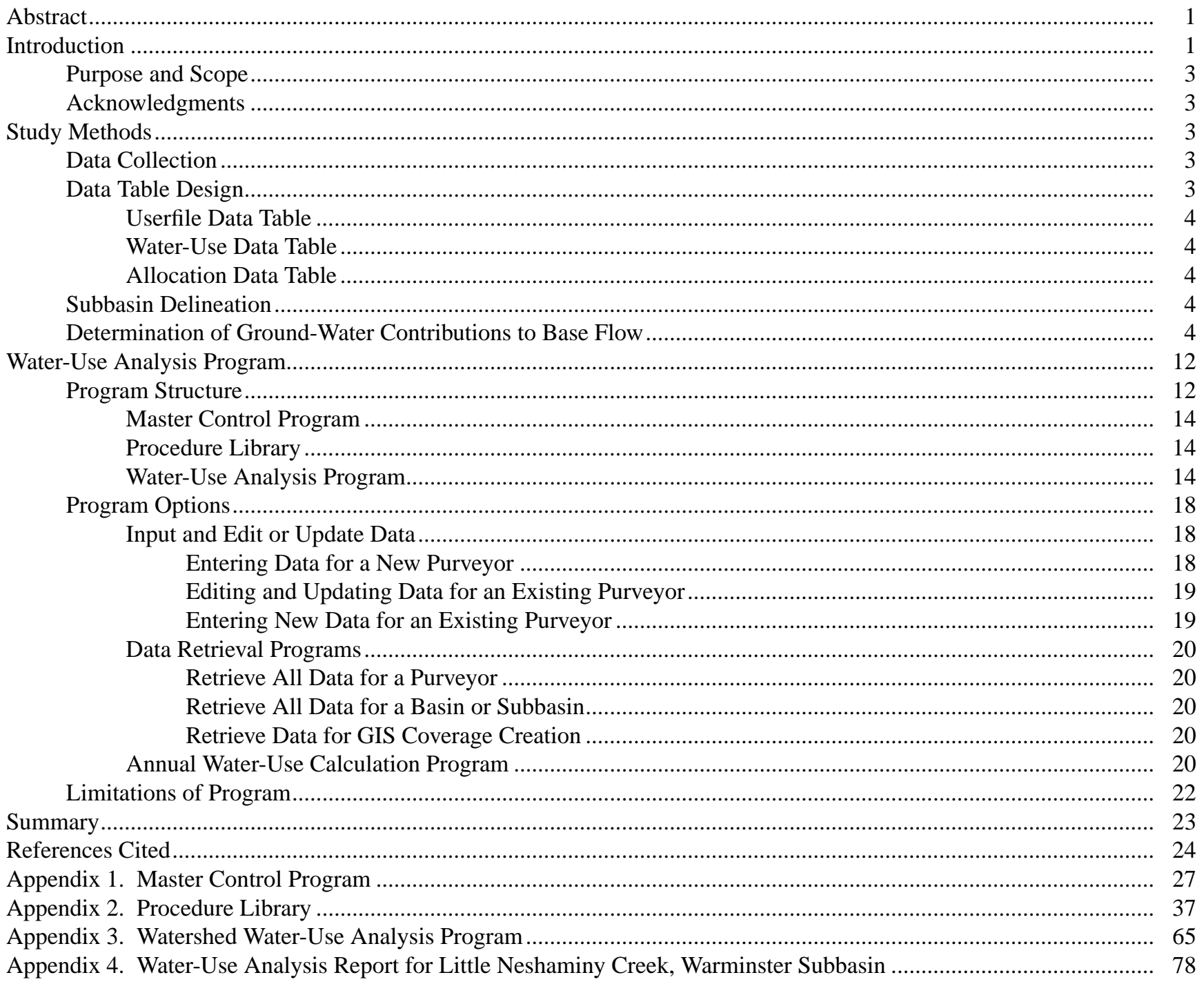

\section{FIGURES}

1-5. Maps showing:

1. Location of the Neshaminy Creek Basin, Pennsylvania

2. Neshaminy Creek Basin and subbasin locations, names, and U.S. Geological Survey assigned basin codes

3. Generalized geology of the Neshaminy Creek Basin, Pennsylvania ....

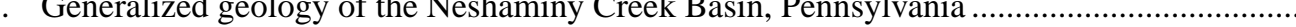

4. Political boundaries in the Neshaminy Creek Basin, Pennsylvania............................................................... 10

5. Location of drainage basins and the four streamflow-measurement stations used in determining base-flow contributions, southeastern Pennsylvania.....

6. Flowchart of the water-use analysis program 


\section{TABLES}

1. Description of fields in userfile data table .............................................................................................

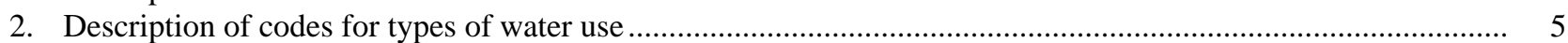

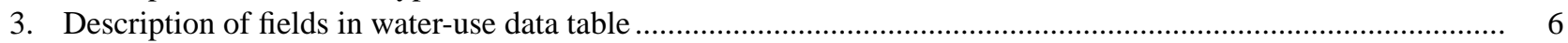

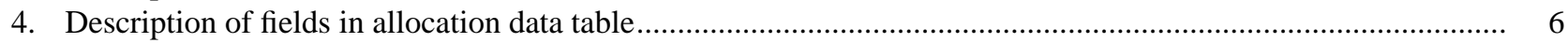

5. U.S. Geological Survey assigned codes, basin and subbasin names, and drainage areas.................................. 8

6. Base-flow recurrence intervals for geologic units or groups in the Neshaminy Creek Basin, Pennsylvania

7. Areal percentages of each geologic unit or group in each basin or subbasin of the

Neshaminy Creek Basin, Pennsylvania.

8. Base-flow recurrence intervals for Neshaminy Creek near Langhorne, Pennsylvania, streamflow-measurement station, water years 1935-93

9. Areal percentages of townships and boroughs in West Branch Neshaminy Creek, Pine Run, North Branch Neshaminy Creek, Doylestown Subbasin Neshaminy Creek, Warwick Subbasin Neshaminy Creek, Warrington Subbasin Little Neshaminy Creek, and Park Creek Basins.....

10. Areal percentages of townships and boroughs in Warminster Subbasin Little Neshaminy Creek, Mill Creek, Northampton Subbasin Neshaminy Creek, Newtown Creek, Core Creek, Ironworks Creek, and Lower Section Subbasin Neshaminy Creek

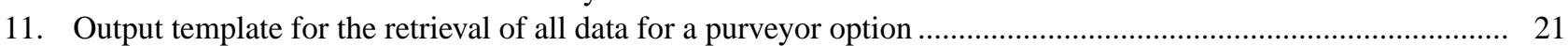

12. Example of retrieval of all data for a basin or subbasin .............................................................................. 22

13. Example output for retrieval of Geographic Information System mapping option using a type of use code of Public Supply Well.

\section{CONVERSION FACTORS}

\begin{tabular}{|c|c|c|}
\hline Multiply & By & To obtain \\
\hline \multicolumn{3}{|c|}{ Area } \\
\hline square mile $\left(\mathrm{mi}^{2}\right)$ & 2.590 & square kilometer \\
\hline \multicolumn{3}{|c|}{ Volume } \\
\hline gallon (gal) & 3.785 & liter \\
\hline \multicolumn{3}{|c|}{ Flow } \\
\hline gallon per day (gal/d) & 0.003785 & cubic meter per day \\
\hline gallon per year (gal/yr) & $1.038 \times 10^{-5}$ & cubic meter per day \\
\hline million gallons per year (Mgal/yr) & 10.3699 & cubic meter per day \\
\hline million gallons per day per square mile $\left[(\mathrm{Mgal} / \mathrm{d}) / \mathrm{mi}^{2}\right]$ &, 461 & cubic meter per day per square kilometer \\
\hline
\end{tabular}




\title{
Water-Use Analysis Program for the Neshaminy Creek Basin, Bucks and Montgomery Counties, Pennsylvania
}

\author{
By Curtis L. Schreffler
}

\section{Abstract}

A water-use analysis computer program was developed for the Neshaminy Creek Basin to assist in managing and allocating water resources in the basin. The program was developed for IBM-compatible personal computers. Basin analysis and the methodologies developed for the Neshaminy Creek Basin can be transferred to other watersheds. The development and structure of the water-use analysis program is documented in this report. The report also serves as a user's guide. The program uses common relational database-management software that allows for water-use data input, editing, updating, and output and can be used to generate a watershed water-use analysis report. The watershed-analysis report lists summations of public-supply well withdrawals; a combination of industrial, commercial, institutional, and ground-water irrigation well withdrawals; spray irrigation systems; a combination of public, industrial, and private surface-water withdrawals; wastewater-treatment-facility discharges; estimates of aggregate domestic ground-water withdrawals on an areal basin or subbasin basis; imports and exports of wastewater across basin or subbasin divides; imports and exports of public water supplies across basin or subbasin divides; estimates of evaporative loss and consumptive loss from product incorporation; industrial septic-system discharges to ground water; and ground-water well-permit allocations.

\section{INTRODUCTION}

The $232 \mathrm{mi}^{2}$ Neshaminy Creek Basin is in a heavily populated area of southeastern Pennsylvania (fig. 1). The demand for water in the Neshaminy Creek Basin has increased greatly over recent years and is expected to increase even more in the future as the population increases. The population of Montgomery Township in Montgomery County is projected to increase by 41 percent by the year 2000 (Montgomery County Planning Commission, 1993). The population of New Britain and Northampton Townships in Bucks County are projected to increase by 29 and 24 percent, respectively, by the year 2000 (Bucks County Planning Commission, 1993). Ground-water withdrawals for public supply and industrial uses in the Neshaminy Creek Basin totaled $4,250 \mathrm{Mgal}$ for the year 1992. Increased pumping of ground water for public, industrial, and commercial uses may cause declining water levels, substantial reductions in local and regional ground-water availability, and streamflow reductions (Sloto and Davis, 1983, p. 26).

Data on ground-water contributions to base flow, quantities and locations of withdrawals, wastewater discharges, and imports and exports across basin or subbasin divides should be current and easily accessible to effectively manage and allocate water resources in the basin. Currently, these data are collected and stored in many places, in assorted formats, and by many different agencies.

The Delaware River Basin Commission (DRBC) manages, protects, and allocates water resources in the Neshaminy Creek Basin. The DRBC was formed by a Federal compact as a water-resources management agency of Delaware, New Jersey, New York, Pennsylvania, and the Federal Government. 


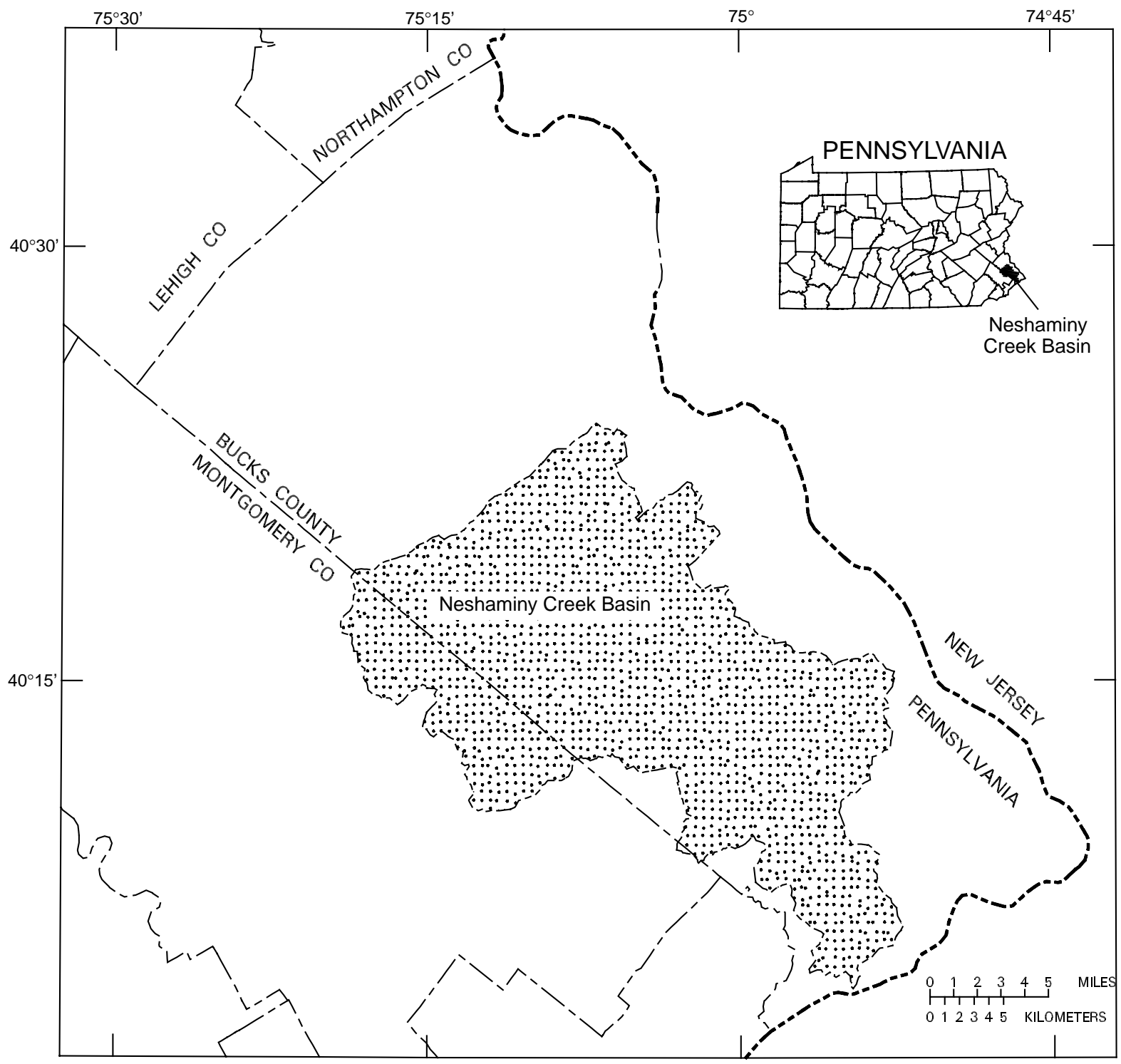

Figure 1. Location of the Neshaminy Creek Basin, Pennsylvania. 
Programs include water-quality protection, watersupply allocation, regulatory review, water conservation, drought management, and flood-loss reduction within the Delaware River Basin. Under provisions of its compact, the DRBC has designated a section of southeastern Pennsylvania as a Ground-Water Protected Area. Most of the Neshaminy Creek Basin lies within this area. Within the protected area, all new or expanded ground-water withdrawals of $10,000 \mathrm{gal} / \mathrm{d}$ or more must be reviewed and approved by the DRBC. In accordance with DRBC Resolution 93-2, ground-water allocations are given for a maximum 10-year period, after which owners must apply for permit renewal.

Data on ground-water contributions to base flow and quantities and locations of water withdrawals, discharges, imports, and exports in Neshaminy Creek Basin were combined into a relational database that can be used to manage and organize the data and to construct a water-use analysis report to summarize and list all available water-use data. This study was done by the U.S. Geological Survey (USGS) in cooperation with the DRBC.

\section{Purpose and Scope}

This report documents the development and structure of the personal computer-based water-use analysis program for the Neshaminy Creek Basin. Data table design and relations between the data tables are discussed. The report describes the menu system and how to input, edit, and retrieve data from the program and generate a basin or subbasin watershed water-use analysis report. Limitations of the water-use analysis program also are discussed.

\section{Acknowledgments}

The Water Supply and Community Health Section of the Pennsylvania Department of Environmental Protection (PaDEP), the Bucks County Planning Commission, the Bucks County Health Department, and the Montgomery County Planning Commission were very helpful in supplying data. Also, many water and sewer system operators and industrial site managers cooperated by providing additional data.

\section{STUDY METHODS}

Data collection, data table design, subbasin delineation, and determination of ground-water contributions to base flow were the primary components in developing the Neshaminy Creek Basin water-use analysis program.

The term "purveyor" in this report refers to owners of water-use facilities, not just providers of water services. Water-use activities are defined as purveyor withdrawals, returns, importations, or exportations of water. Type of use refers to any water-use activity, not actual water usage by individuals or industries.

\section{Data Collection}

The DRBC staff collected all water-use data for the program using the following conventions. All water-use activities listed in the PaDEP's State Water-Use Data System (SWUDS) were included in the data tables. Additional water-use activities were included on the basis of DRBC records of surface-water use. For water purveyors with total water use less than 1,000 gal/d, only information contained in the SWUDS annual records for the most recent year available were entered into the data tables and no additional inquiries to the water purveyor were made. For water purveyors with total water use between 1,000 and 10,000 gal/d, the most recent water-use data from SWUDS were entered into the data tables including monthly usage totals with an estimate for annual water use. Inquiries were made to water purveyors with total water use greater than $10,000 \mathrm{gal} / \mathrm{d}$ or greater than $2.5 \mathrm{Mgal} / \mathrm{yr}$ to update the total water-use monthly data through 1992.

\section{Data Table Design}

Three common key fields are included in each data table, PURV_CODE, PURV_NAME, and PURV_ID. These key fields must be coded in each data table because the tables are indexed and related by these fields. The PURV_CODE field contains a unique six-character identification code assigned by the DRBC to each purveyor. The PURV_NAME field contains a 40-character name assigned by DRBC to each record. The PURV_ID field contains a unique 
eight-character identifier assigned by DRBC for each water-use activity for each record.

\section{Userfile Data Table}

The userfile data table contains data describing the physical location of a purveyor's withdrawal, return, importation, or exportation of water, which includes the source and destination basin, or subbasin, of the activity. The data type, field width, if the field is mandatory, and a definition for each field name are listed in table 1. Included in this data table is a field for type of use (TYPE_USE), which identifies the withdrawals, returns, importations, or exportations. The codes and definitions for each type of use are listed in table 2.

\section{Water-Use Data Table}

The water-use data table contains water-use totals for each purveyor. Annual and monthly usage totals are stored along with the year for that use. The table also includes the type of use field (table 2). The data type, field width, if the field is mandatory, and a definition for each field name are listed in table 3.

\section{Allocation Data Table}

The allocation data table contains the DRBCassigned allocation for a particular withdrawal. Joint allocation fields are used for allocations that are issued to a well field in which more than one well shares an allocation. A maximum of 10-joint allocation fields are available. The 10-joint allocation fields contain well identification names and numbers. A field for a purveyor's total system allocation also is included. The data type, field width, if the field is mandatory, and a definition for each field name are listed in table 4.

\section{Subbasin Delineation}

A Geographic Information System (GIS) was used to create areal coverages of drainage basin divides, bedrock geology, and political boundaries for the Neshaminy Creek Basin. Drainage basin divides were digitized from USGS 1:24,000-scale 7 1/2-minute topographic quadrangle maps. The Neshaminy Creek Basin, excluding the mainstem lower section, was divided into 13 basins or subbasins so that the basin or subbasin areas were not greater than $25 \mathrm{mi}^{2}$. The mainstem Neshaminy Creek, lower section subbasin (area 14), has a drainage area of $41.7 \mathrm{mi}^{2}$ (fig. 2). The drainage basin coverages were used in determining ground-water contributions to base flow for the basins or subbasins on the basis of geology. Assigned codes, basin and subbasin names, and drainage areas are listed in table 5. A basin code of ' 00 ' was added to the program to track water-use activities that either originate or terminate outside of the Neshaminy Creek Basin.

Bedrock geologic contact lines were transferred to USGS 1:24,000-scale 7 1/2-minute topographic quadrangle maps from the 1:250,000-scale geologic map of Lyttle and Epstein (1987) and the 1:62,500scale geologic map of Longwill and Wood (1965) and were digitized. The geology coverage was used to calculate the percentage of each geologic unit in each subbasin. The geologic units were grouped into four geologic categories that were used in determining ground-water contributions to base flow for the basins or subbasins. The geologic groups are the Brunswick Group and Lockatong Formation, the Stockton Formation, carbonate rocks, and crystalline rocks (fig. 3).

Political boundaries for Bucks County were digitized from mylar USGS 1:50,000-scale county topographic maps. Political boundaries for Montgomery County were digitized from USGS 1:24,000-scale 7 1/2-minute topographic quadrangle maps. Political boundary coverages were used in estimating aggregate annual domestic water use in a basin or subbasin (fig. 4).

\section{Determination of Ground-Water Contributions to Base Flow}

Estimates of annual base flow for four streamflow-measurement stations in southeastern Pennsylvania were used to estimate the ground-water contribution to base flow of the four geologic units or groups in the Neshaminy Creek Basin (R.E. Wright Associates, Inc. [n.d.], p. 6-31; Delaware River Basin Commission, written commun., 1995) (fig. 5). The hydrograph-separation computer program of Sloto (1991) was used to separate the surface-runoff and base-flow or ground-water-discharge components of streamflow. The local-minimum method was used. A normal frequency distribution was used to determine 
Table 1. Description of fields in userfile data table

[Y, field is mandatory; N, field is not mandatory; UTM, Universal Transverse Mercator map projection; USGS, U.S. Geological Survey; DRBC, Delaware River Basin Commission; PaDEP, Pennsylvania Department of Environmental Protection]

\begin{tabular}{|c|c|c|c|c|}
\hline Field name & Data type & $\begin{array}{l}\text { Field } \\
\text { width }\end{array}$ & $\begin{array}{l}\text { Mandatory } \\
\text { field }\end{array}$ & Definition \\
\hline PURV_NAME & Character & 40 & $\mathrm{Y}$ & $\begin{array}{l}\text { Name of public-water purveyor, well owner, municipal authority, or sewage- } \\
\text { treatment-plant operator. }\end{array}$ \\
\hline PURV_CODE & Character & 6 & Y & Unique user identification code assigned to each purveyor by DRBC. \\
\hline PURV_ID & Character & 8 & $\mathrm{Y}$ & Unique identifier assigned by DRBC for each water-use activity. \\
\hline USGS_LOCAL & Character & 8 & $\mathrm{~N}$ & USGS (Pennsylvania district) local well-identification number. \\
\hline TYPE_USE & Character & 3 & Y & Type of use (see table 2). \\
\hline LOC_LAT & Character & 6 & Y & $\begin{array}{l}\text { Latitude location of withdrawal, return, importation, or exportation point } \\
\text { (degrees, minutes, seconds). }\end{array}$ \\
\hline LOC_LONG & Character & 7 & Y & $\begin{array}{l}\text { Longitude location of withdrawal, return, importation, or exportation point } \\
\text { (degrees, minutes, seconds). }\end{array}$ \\
\hline UTM18_X & Character & 6 & $\mathrm{~N}$ & $\begin{array}{l}\text { UTM X-coordinate of withdrawal, return, importation, or exportation point, } \\
\text { in meters. }\end{array}$ \\
\hline UTM18_Y & Character & 7 & $\mathrm{~N}$ & $\begin{array}{l}\text { UTM Y-coordinate of withdrawal, return, importation, or exportation point, } \\
\text { in meters. }\end{array}$ \\
\hline GUNIT_CODE & Character & 8 & $\mathrm{~N}$ & USGS geologic unit code of the aquifer. \\
\hline BASIN_SOR & Character & 2 & Y & $\begin{array}{l}\text { Basin or subbasin location code for point of withdrawal or exportation } \\
\text { (see table 5). }\end{array}$ \\
\hline SSTM_CODE & Character & 6 & $\mathrm{~N}$ & PaDEP stream code for point of surface-water withdrawal. \\
\hline SRV_MILE & Numeric & 6 & $\mathrm{~N}$ & River mile for point of surface-water withdrawal. \\
\hline BASIN_DEST & Character & 2 & $\mathrm{Y}$ & Basin or subbasin location code for point of return (see table 5). \\
\hline DSTM_CODE & Character & 6 & $\mathrm{~N}$ & PaDEP stream code for point of return to surface water. \\
\hline DRV_MILE & Numeric & 6 & $\mathrm{~N}$ & River mile at point of return to surface water. \\
\hline DRBC_DOC & Character & 15 & $\mathrm{~N}$ & DRBC docket number. \\
\hline
\end{tabular}

Table 2. Description of codes for types of water use

\begin{tabular}{cl}
\hline $\begin{array}{c}\text { Type of } \\
\text { use code }\end{array}$ & \multicolumn{1}{c}{ Definition } \\
\hline PSW & Public-supply ground-water withdrawal. \\
SWW & Surface-water withdrawal for purposes of public supply, processing water, fire fighting, etc. \\
INW & Industrial, commercial, or institutional ground-water withdrawal. \\
STP & Sewage-treatment-plant discharge. \\
TID & Treated industrial, commercial, or institutional discharge to surface water. \\
GWI & Ground-water withdrawals for purposes of irrigation. \\
SWI & Surface-water withdrawals for purposes of irrigation. \\
WSI & Water-supply import. \\
WSE & Water-supply export. \\
DIM & Effluent discharge import. \\
DEX & Effluent discharge export. \\
SEP & Septic tank discharge. \\
PRO & Consumptive losses due to product incorporation. \\
EVP & Estimates of evaporative losses. \\
RCG & Ground-water recharge (discharge to ground water). \\
SPR & Spray irrigation (effluent discharge to ground water). \\
\hline
\end{tabular}


Table 3. Description of fields in water-use data table

[Y, field is mandatory; $\mathrm{N}$, field is not mandatory; DRBC, Delaware River Basin Commission]

\begin{tabular}{|c|c|c|c|c|}
\hline Field name & Data type & $\begin{array}{l}\text { Field } \\
\text { width }\end{array}$ & $\begin{array}{l}\text { Mandatory } \\
\text { fields }\end{array}$ & Definition \\
\hline PURV_NAME & Character & 40 & $\mathrm{Y}$ & $\begin{array}{l}\text { Name of public-water purveyor, well owner, municipal authority, } \\
\text { or sewage-treatment-plant operator. }\end{array}$ \\
\hline PURV_CODE & Character & 6 & Y & Unique user identification code assigned to each purveyor by DRBC. \\
\hline PURV_ID & Character & 8 & Y & Unique identifier assigned by DRBC for each water-use activity. \\
\hline TYPE_USE & Character & 3 & Y & Type of use (see table 2). \\
\hline ANN_YEAR & Character & 2 & Y & Year of reported data. \\
\hline ANNUAL_TOT & Numeric & 10 & Y & Total annual usage for the year, in million gallons. \\
\hline JAN_TOTAL & Numeric & 10 & $\mathrm{~N}$ & Total monthly usage for January, in million gallons. \\
\hline FEB_TOTAL & Numeric & 10 & $\mathrm{~N}$ & Total monthly usage for February, in million gallons. \\
\hline MAR_TOTAL & Numeric & 10 & $\mathrm{~N}$ & Total monthly usage for March, in million gallons. \\
\hline APR_TOTAL & Numeric & 10 & $\mathrm{~N}$ & Total monthly usage for April, in million gallons. \\
\hline MAY_TOTAL & Numeric & 10 & $\mathrm{~N}$ & Total monthly usage for May, in million gallons. \\
\hline JUN_TOTAL & Numeric & 10 & $\mathrm{~N}$ & Total monthly usage for June, in million gallons. \\
\hline JUL_TOTAL & Numeric & 10 & $\mathrm{~N}$ & Total monthly usage for July, in million gallons. \\
\hline AUG_TOTAL & Numeric & 10 & $\mathrm{~N}$ & Total monthly usage for August, in million gallons. \\
\hline SEP_TOTAL & Numeric & 10 & $\mathrm{~N}$ & Total monthly usage for September, in million gallons. \\
\hline OCT_TOTAL & Numeric & 10 & $\mathrm{~N}$ & Total monthly usage for October, in million gallons. \\
\hline NOV_TOTAL & Numeric & 10 & $\mathrm{~N}$ & Total monthly usage for November, in million gallons. \\
\hline DEC_TOTAL & Numeric & 10 & $\mathrm{~N}$ & Total monthly usage for December, in million gallons. \\
\hline
\end{tabular}

Table 4. Description of fields in allocation data table

[Y, field is mandatory; N, field is not mandatory; DRBC, Delaware River Basin Commission]

\begin{tabular}{|c|c|c|c|c|}
\hline Field name & Data type & $\begin{array}{l}\text { Field } \\
\text { width }\end{array}$ & $\begin{array}{l}\text { Mandatory } \\
\text { field }\end{array}$ & Definition \\
\hline PURV_NAME & Character & 40 & $\mathrm{Y}$ & $\begin{array}{l}\text { Name of public-water purveyor, well owner, municipal authority, } \\
\text { or sewage-treatment-plant operator. }\end{array}$ \\
\hline PURV_CODE & Character & 6 & Y & Unique user identification code assigned to each purveyor by DRBC. \\
\hline PURV_ID & Character & 8 & Y & Unique identifier assigned by DRBC for each water-use activity. \\
\hline ALLOCATION & Numeric & 10 & $\mathrm{~N}$ & $\begin{array}{l}\text { Individual allocation for the withdrawal, in million gallons for a } \\
\text { 30-day period. }\end{array}$ \\
\hline JT_ALLOC & Numeric & 10 & $\mathrm{~N}$ & Joint allocation, in million gallons for a 30 -day period. \\
\hline JT_ID1 & Character & 40 & $\mathrm{~N}$ & $\begin{array}{l}\text { Individual well identification names and numbers that are included in } \\
\text { the joint allocation. }\end{array}$ \\
\hline JT_ID2 & Character & 40 & $\mathrm{~N}$ & Do. \\
\hline JT_ID3 & Character & 40 & $\mathrm{~N}$ & Do. \\
\hline JT_ID4 & Character & 40 & $\mathrm{~N}$ & Do. \\
\hline JT_ID5 & Character & 40 & $\mathrm{~N}$ & Do. \\
\hline JT_ID6 & Character & 40 & $\mathrm{~N}$ & Do. \\
\hline JT_ID7 & Character & 40 & $\mathrm{~N}$ & Do. \\
\hline JT_ID8 & Character & 40 & $\mathrm{~N}$ & Do. \\
\hline JT_ID9 & Character & 40 & $\mathrm{~N}$ & Do. \\
\hline JT_ID10 & Character & 40 & $\mathrm{~N}$ & Do. \\
\hline SYS_ALLOC & Numeric & 10 & $\mathrm{~N}$ & Total system allocation, in million gallons for a 30 -day period. \\
\hline
\end{tabular}




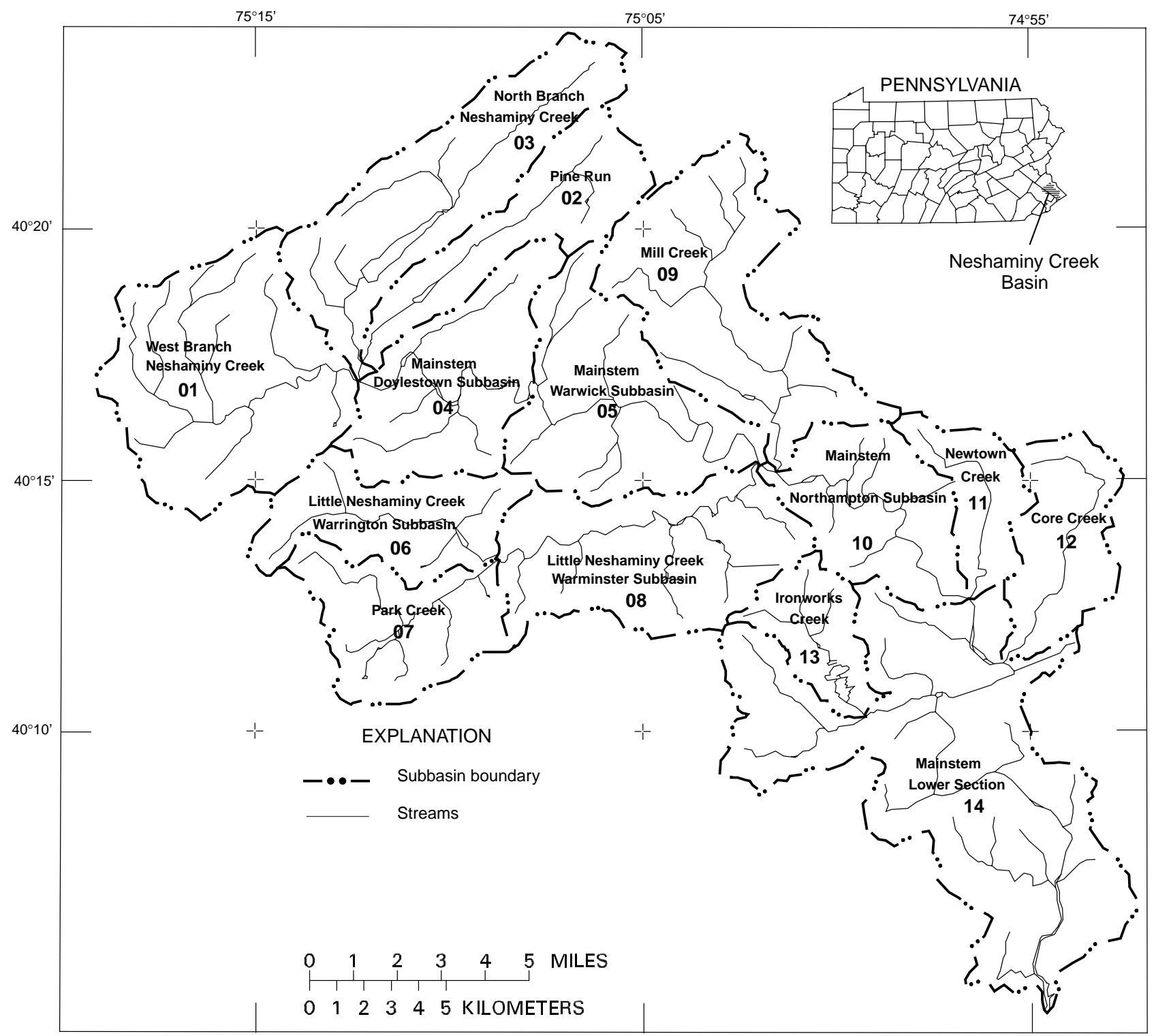

Figure 2. Neshaminy Creek Basin and subbasin locations, names, and U.S. Geological Survey assigned basin codes. 
Table 5. U.S. Geological Survey assigned codes, basin and subbasin names, and drainage areas

\begin{tabular}{clc}
{$[--$, not applicable] } & \\
\hline Code & \multicolumn{1}{c}{ Basin or Subbasin } & $\begin{array}{c}\text { Drainage area } \\
\text { (square miles) }\end{array}$ \\
\hline 00 & Basins outside Neshaminy Creek Basin & -- \\
01 & West Branch Neshaminy Creek Basin & 25.0 \\
02 & Pine Run Basin & 11.6 \\
03 & North Branch Neshaminy Creek Basin & 20.0 \\
04 & Mainstem Neshaminy Creek, Doylestown Subbasin & 15.4 \\
05 & Mainstem Neshaminy Creek, Warwick Subbasin & 18.8 \\
06 & Little Neshaminy Creek, Warrington Subbasin & 11.5 \\
07 & Park Creek Basin & 11.8 \\
08 & Little Neshaminy Creek, Warminster Subbasin & 19.7 \\
09 & Mill Creek Basin & 21.9 \\
10 & Mainstem Neshaminy Creek, Northampton Subbasin & 12.6 \\
11 & Newtown Creek Basin & 6.3 \\
12 & Core Creek Basin & 9.8 \\
13 & Ironworks Creek Basin & 6.3 \\
14 & Mainstem Neshaminy Creek, Lower Subbasin & 41.7
\end{tabular}

annual base flow for the 2-, 5-, 10-, 25-, and 50-year recurrence intervals at the four streamflowmeasurement stations. Base-flow recurrence intervals for water years 1961-93 for the West Branch of Brandywine Creek near Honeybrook, Pa., which drains nearly 100 percent crystalline rocks, were used to estimate yields for the crystalline rocks in the Neshaminy Creek Basin (R.E. Wright Associates, Inc. [n.d.], p. 6-31; Delaware River Basin Commission, written commun., 1995). Base-flow recurrence intervals for water years 1967-93 for Skippack Creek near Collegeville, Pa., were used to estimate yields for the Brunswick Group and Lockatong Formation. The period of record for these two stations was not of sufficient length to calculate the 50-year recurrence base-flow values. Therefore, the 50 -year base-flow values were determined by plotting the $2-, 5-, 10-$, and 25 -year base flows on semilogarithmic paper and extrapolating the curves.

Base-flow recurrence intervals for 1946-93 for Little Lehigh Creek near Allentown, Pa., were used to estimate yields for the carbonate rocks. For the Little Lehigh Creek base-flow frequency determination, the drainage area above the streamflow-measurement station was adjusted by reducing the area by $7.8 \mathrm{mi}^{2}$. Wood and others (1972, p. 17) state that the ground-water basin contributing most of the stream- flow passing the streamflow-gaging station is smaller than the surface-water basin. A combination of underflow and direct diversions accounted for the differing ground- and surface-water divides. Wood and others $\left(1972\right.$, p. 20) state that $7.8 \mathrm{mi}^{2}$ of the ground-water basin drains to Shantz Spring and Cedar Creek. Sloto and others (1991, p. 24) show that the drainage divide between the Little Lehigh Creek and Shantz Spring was nearly at the same location in 1984 as the divide on the 1968 water-table map of Wood and others (1972, pls. 1 and 4A).

R.E. Wright Associates, Inc. [n.d.] (p. 6-31) identified the Pennypack Creek Basin to be representative of the Stockton Formation base-flow contributions to the Neshaminy Creek Basin. However, hydrograph separation for the period of record for Pennypack Creek at Pine Road, Philadelphia, Pa., yielded very high estimates of the Stockton Formation base-flow contributions for each recurrence interval. The method (R.E. Wright Associates, Inc. [n.d.], p. 6-31) for estimating base-flow contributions of the Stockton Formation was not used in this investigation. The following method was used to determine base-flow contributions of the Stockton Formation in the Neshaminy Creek Basin. The 2-, 5-, 10-, 25-, and 50 -year base-flow recurrence intervals for a common period of record (water years 1966-92) were 


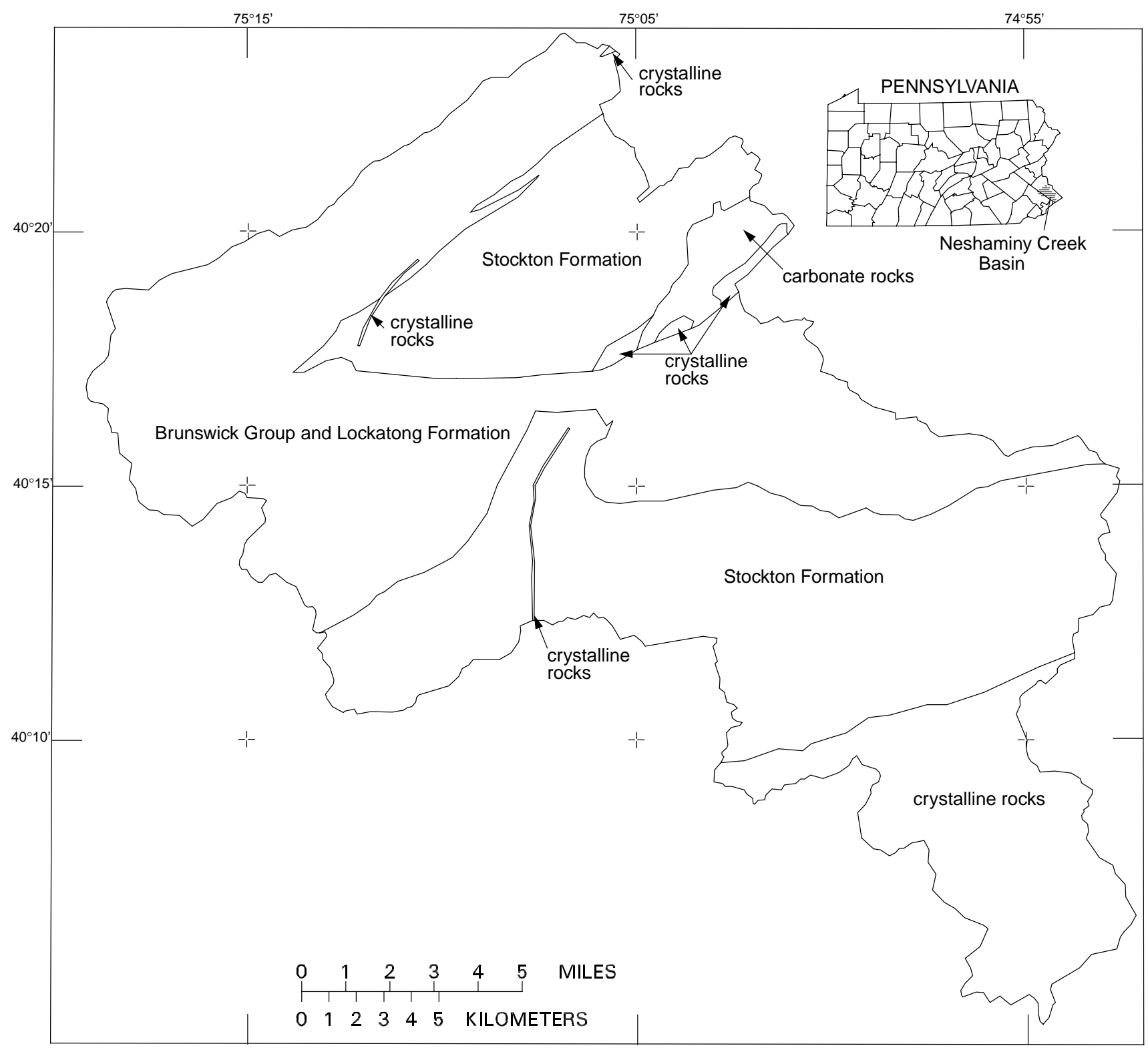

Figure 3. Generalized geology of the Neshaminy Creek Basin, Pennsylvania. 


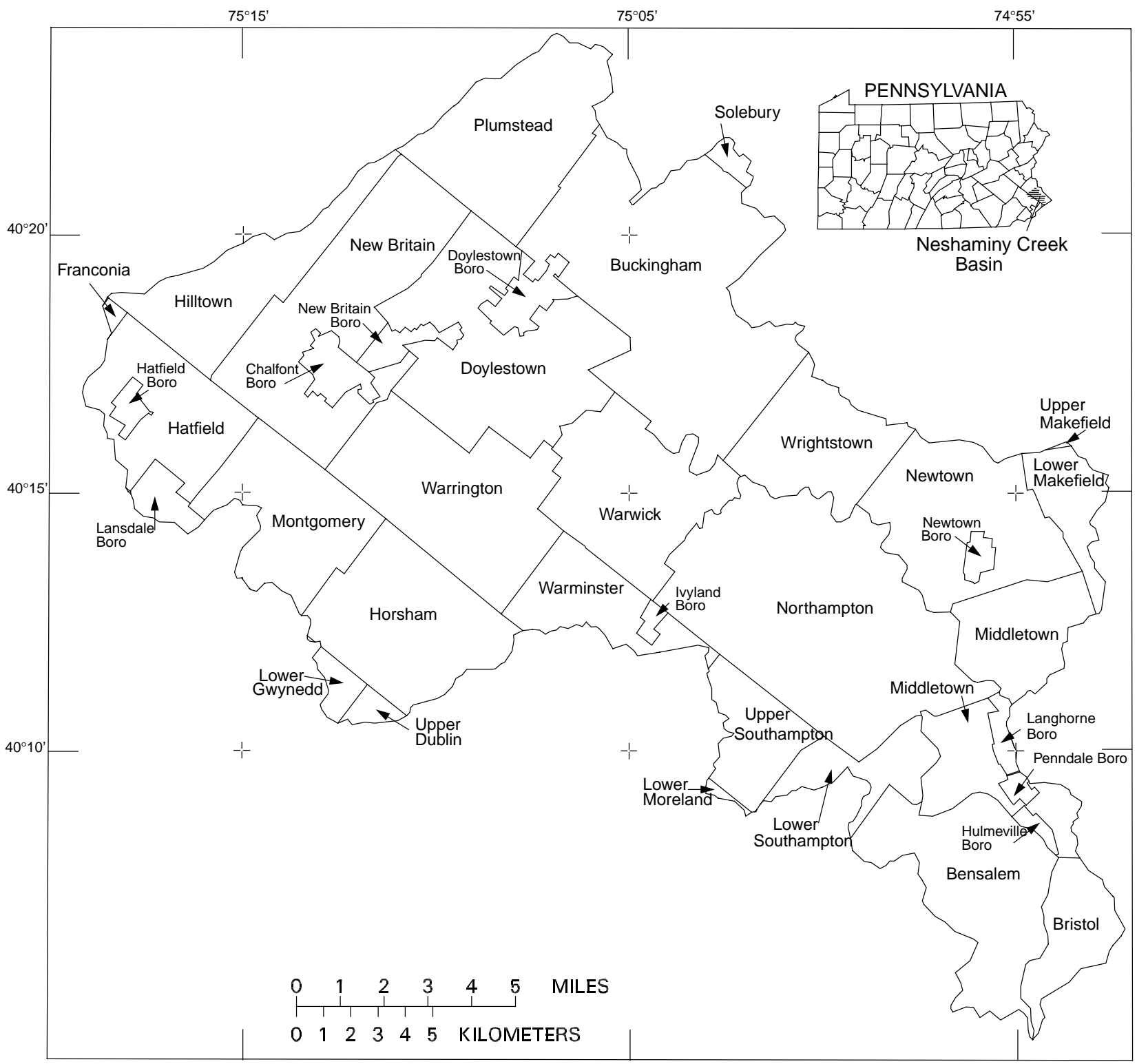

Figure 4. Political boundaries in the Neshaminy Creek Basin, Pennsylvania. 


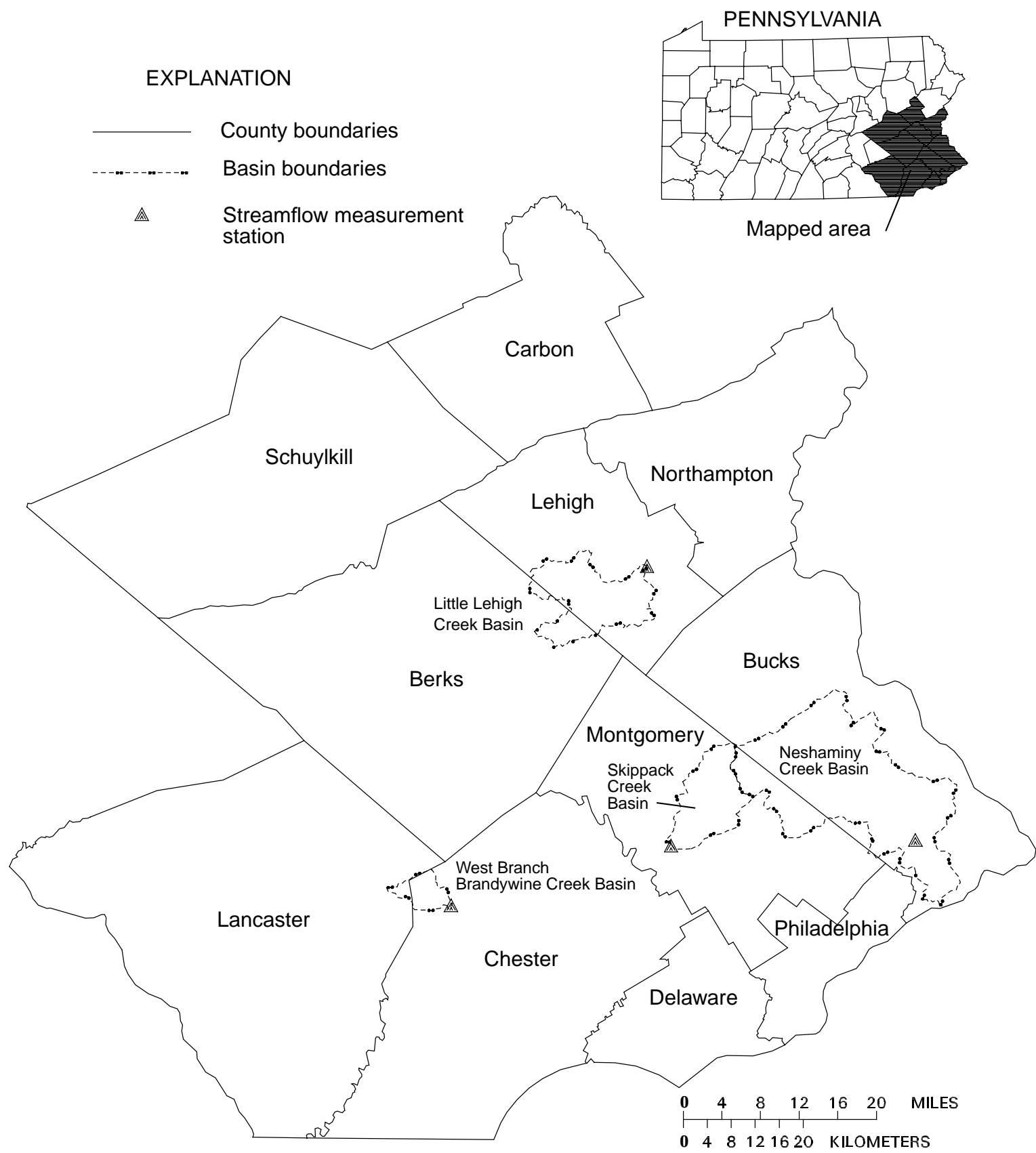

Figure 5. Location of drainage basins and the four streamflow-measurement stations used in determining base-flow contributions, southeastern Pennsylvania. 
recalculated for the West Branch of Brandywine Creek near Honeybrook, Pa., Skippack Creek, Little Lehigh Creek, and Neshaminy Creek near Langhorne, Pa. The areal percentages of different geologic units above the streamflow-measurement station on Neshaminy Creek at Langhorne were determined from the GIS. The known base-flow values for each recurrence interval were substituted into equation 1 to solve for the base-flow contribution from the Stockton Formation.

$$
\begin{gathered}
\mathrm{Q}_{\text {Neshaminy }}=\left(\mathrm{Q}_{\mathrm{W} . \text { Br. Brandywine }}\right) \\
(\text { Percent Area } \text { crystalline rocks })+ \\
\left(\mathrm{Q}_{\text {Skippack }}\right)(\text { Percent Area } \text { Brunswick/Lockatong })+ \\
\left(\mathrm{Q}_{\text {Little Lehigh }}\right)(\text { Percent Area } \\
\left(\mathrm{Q}_{\text {Stocktonate rock }}\right)\left(\text { Percent } \text { Area }_{\text {Stockton }}\right)
\end{gathered}
$$

The 2-, 5-, 10-, 25-, and 50-year recurrence intervals for base flow determined in this investigation from each geologic unit or group in million gallons per day per square mile are listed in table 6 . The percentages of each geologic unit or group in each basin or subbasin was determined from the GIS (table 7) and then multiplied by the respective recurrence-interval value (table 6) and summed to determine the basin or subbasin ground-water contribution to base flow in million gallons per day per square mile.

Because of the lack of data for base-flow contributions of the unconsolidated deposits in the Neshaminy Creek lower section, the ground-water contribution to base flow of these deposits was not included in the estimates for this subbasin. For the area underlain by unconsolidated deposits, base-flow values for the crystalline rocks were used in determining ground-water contributions to base flow in the Neshaminy Creek lower section.

A hydrograph separation was performed for water years 1935-93 for Neshaminy Creek near Langhorne by use of the hydrograph-separation program of Sloto (1991). The local minimum technique was used. The 2-, 5-, 10-, 25-, and 50-year recurrence intervals for base flow for the period of record for the streamflow-measurement station Neshaminy Creek near Langhorne, Pa., are listed in table 8 .

\section{WATER-USE ANALYSIS PROGRAM}

The Neshaminy Creek water-use analysis program was developed using dBASE IV version 2.0 relational database software. The water-use program was written for IBM or IBM-compatible personal computers with a minimum of 2 megabytes (MB) of random-access-memory (RAM). The minimum hard disk space required is $10 \mathrm{MB}$. Additional hard disk memory may be required as more data is entered into the data tables.

\section{Program Structure}

The master control program (masterpr.prg) for the water-use analysis program is the main controlling program. The main menu and submenus are activated and defined in the master control program. All other programs, known as procedures, are called from the

\begin{tabular}{|c|c|c|c|c|c|}
\hline \multirow{3}{*}{ Geologic unit or group } & \multicolumn{5}{|c|}{ Base-flow recurrence interval } \\
\hline & 2-year & 5-year & 10-year & 25-year & 50-year \\
\hline & \multicolumn{5}{|c|}{$\begin{array}{c}\text { Discharge } \\
{\left[(\mathrm{Mgal} / \mathrm{d}) / \mathrm{mi}^{2}\right]}\end{array}$} \\
\hline Brunswick Group and Lockatong Formation & 0.314 & 0.241 & 0.189 & 0.154 & 0.144 \\
\hline Stockton Formation & .627 & .401 & .343 & .189 & .158 \\
\hline Carbonate rocks & .706 & .481 & .408 & .289 & .278 \\
\hline Crystalline rocks & .524 & .381 & .302 & .299 & .206 \\
\hline
\end{tabular}
master control program. The procedure library (proclib.prg) is a file that includes all the procedures

Table 6. Base-flow recurrence intervals for geologic units or groups in the Neshaminy Creek Basin, Pennsylvania

$\left[(\mathrm{Mgal} / \mathrm{d}) / \mathrm{mi}^{2}\right.$, million gallons per day per square mile] 
Table 7. Areal percentages of each geologic unit or group in each basin or subbasin of the Neshaminy Creek Basin, Pennsylvania

[--, not applicable]

\begin{tabular}{|c|c|c|c|c|c|c|c|}
\hline \multirow[b]{2}{*}{$\begin{array}{l}\text { Subbasin and } \\
\text { code number }\end{array}$} & \multicolumn{7}{|c|}{ Geologic unit or group } \\
\hline & Pleistocene & Diabase & $\begin{array}{l}\text { Brunswick } \\
\text { Group }\end{array}$ & $\begin{array}{l}\text { Lockatong } \\
\text { Formation }\end{array}$ & $\begin{array}{l}\text { Stockton } \\
\text { Formation }\end{array}$ & $\begin{array}{l}\text { Carbonate } \\
\text { rocks }\end{array}$ & $\begin{array}{l}\text { Crystalline } \\
\text { rocks }\end{array}$ \\
\hline $\begin{array}{l}\text { West Branch Neshaminy } \\
\text { Creek Basin }-01\end{array}$ & $\overline{--}$ & -- & 62.4 & 37.0 & 0.6 & -- & -- \\
\hline Pine Run Basin - 02 & -- & 1.0 & -- & 8.0 & 91.0 & -- & -- \\
\hline $\begin{array}{l}\text { North Branch Neshaminy } \\
\text { Creek }-03\end{array}$ & -- & .2 & .4 & 95.4 & 4.0 & -- & -- \\
\hline $\begin{array}{l}\text { Doylestown Subbasin } \\
\quad \text { Neshaminy Creek — } 04\end{array}$ & -- & -- & 6.5 & 51.2 & 42.3 & -- & -- \\
\hline $\begin{array}{l}\text { Warwick Subbasin Neshaminy } \\
\text { Creek }-05\end{array}$ & -- & .4 & -- & 55.8 & 41.6 & -- & 2.2 \\
\hline $\begin{array}{c}\text { Warrington Subbasin Little } \\
\text { Neshaminy Creek — } 06\end{array}$ & -- & -- & -- & 85.0 & 15.0 & -- & -- \\
\hline Park Creek Basin -07 & -- & -- & -- & 23.6 & 76.4 & -- & -- \\
\hline $\begin{array}{c}\text { Warminster Subbasin Little } \\
\text { Neshaminy Creek — } 08\end{array}$ & -- & .6 & -- & 2.3 & 97.1 & -- & -- \\
\hline Mill Creek Basin — 09 & -- & -- & 34.7 & 11.1 & 31.6 & 18.3 & 4.3 \\
\hline $\begin{array}{l}\text { Northampton Subbasin } \\
\quad \text { Neshaminy Creek }-10\end{array}$ & -- & -- & 2.1 & 45.6 & 52.3 & -- & -- \\
\hline Newtown Creek - 11 & -- & -- & 5.5 & 39.5 & 55.0 & -- & -- \\
\hline Core Creek Basin - 12 & -- & -- & -- & 11.3 & 88.7 & -- & -- \\
\hline Ironworks Creek Basin -13 & -- & -- & -- & -- & 100.0 & -- & -- \\
\hline $\begin{array}{l}\text { Lower Section Subbasin } \\
\quad \text { Neshaminy Creek - } 14\end{array}$ & 27.4 & -- & -- & -- & 30.9 & -- & ${ }^{1} 41.7$ \\
\hline
\end{tabular}

${ }^{1}$ Chickies quartzite - 2.8; Wissahickon schist - 16.7; gneiss - 22.2 percent.

Table 8. Base-flow recurrence intervals for Neshaminy Creek near Langhorne, Pennsylvania, streamflow-measurement station, water years 1935-93

$\left[(\mathrm{Mgal} / \mathrm{d}) / \mathrm{mi}^{2}\right.$, million gallons per day per square mile]

\begin{tabular}{|c|c|c|c|c|}
\hline \multicolumn{5}{|c|}{ Base-flow recurrence interval } \\
\hline 2-year & 5-year & 10-year & 25-year & 50-year \\
\hline \multicolumn{5}{|c|}{$\begin{array}{c}\text { Discharge } \\
{\left[(\mathrm{Mgal} / \mathrm{d}) / \mathrm{mi}^{2}\right]}\end{array}$} \\
\hline 0.411 & 0.299 & 0.248 & 0.195 & 0.179 \\
\hline
\end{tabular}


used by the program. The watershed water-use analysis program is stored in the file analysis.prg. Appendix 1 lists the code for the master control program. Appendix 2 lists the code for the procedure library. Appendix 3 lists the code for the watershed water-use analysis. A flow chart of the program structure is shown in figure 6.

\section{Master Control Program}

The master control program declares and initializes all public memory variables, which are memory variables that are used by more than one program, and initializes all environment variables. The initial data table indexes are defined in the program. The program contains a series of menus, procedures, and decision constructs in which all subsequent procedures used in the program are called. Decision constructs are structured program commands that select only one course of action from a set of alternatives.

\section{Procedure Library}

The procedure library, which contains 22 procedures, was created to save compiling time. The procedure is compiled at run time, and the compiled file is stored in the user's current directory. When a program is called, the procedure library is searched and the called procedure is executed.

The procedure library contains all screen definition forms for input and editing of data. The file contains menu and submenu definitions and subsequent decision constructs for the output destination menu, ground-water availability menu, and the printer retry menu. The procedure PrntRtry (Appendix 2) displays an error message when the operator requests printed output and the printing device is not ready. The library also contains all procedures that create indexes or temporary data tables.

\section{Water-Use Analysis Program}

The water-use analysis program file contains the code to generate the watershed water-use analysis report. It is called from a procedure in the procedure library. All memory variables are initialized, and a temporary data table is created from the water-use data table, which is sorted on fields PURV_CODE, PURV_ID, and ANN_YEAR. The fields PURV_CODE and PURV_ID are sorted in ascending order; the ANN_YEAR field is sorted in descending order. The temporary table is then indexed on PURV_ID with the condition that the ANN_YEAR field is equal to or less than the user-specified year.

The other two data tables, userfile and aloc (the allocation table), are indexed on PURV_ID and related to the temporary table by PURV_ID. A filter is used to extract records with a source or destination basin code that matches the user-specified basin code. All listings, totals, and comparisons are determined from the temporary data table.

To generate the water-use analysis report, a combination of procedures are called by the program (for example, gwyield.prg, gw_comp.prg, and output reports that reside in the subdirectory |reports\). The output includes listings and summations of yearly usage totals for the user-specified year or the most recently available data. The output report lists and totals annual totals for the following water-use activities: public-supply well withdrawals; a combination of industrial, commercial, institutional, and ground-water-irrigation well withdrawals; spray irrigation systems; surface-water withdrawals; wastewater-treatment-facility discharges to surface water; estimates of areally distributed aggregate domestic ground-water withdrawals in a basin or subbasin; interbasin imports and exports of wastewater; interbasin imports and exports of public-supply water; estimates of evaporative losses and consumptive use from product incorporation; industrial septic-system discharges; and individual DRBC-assigned well allocation amounts for the selected basin or subbasin. At the end of the report, comparisons are given among the estimates of groundwater contributions to base flow, total ground-water withdrawals, and annual total allocations. Appendix 4 contains a watershed water-use analysis report for the Little Neshaminy Creek, Warminster Subbasin.

The annual total of areally distributed groundwater withdrawals by domestic users was determined by first calculating the areal percentage of each township or borough in a basin or subbasin (tables 9 and 10). The DRBC provided data on the population not served by a public-water system in each township or borough, which was used to represent domestic users (Delaware River Basin Commission, written commun., 1993). Assuming an even areal distribution of domestic users in each township or borough, the domestic-use population for each subbasin was calculated. This population was multiplied by the 


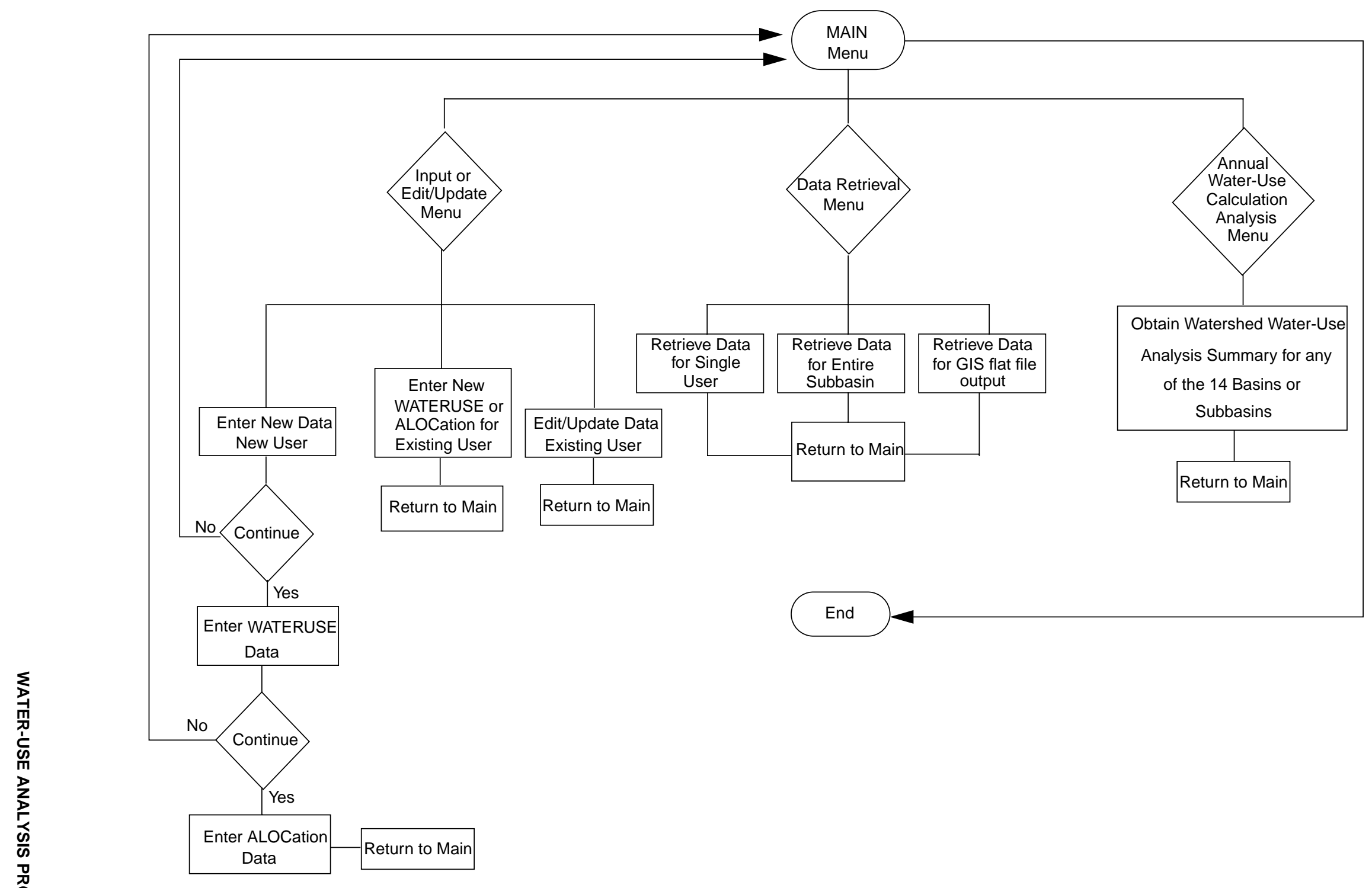

Figure 6. Flowchart of the water-use analysis program. 
Table 9. Areal percentages of townships and boroughs in West Branch Neshaminy Creek, Pine Run, North Branch Neshaminy Creek, Doylestown Subbasin Neshaminy Creek, Warwick Subbasin Neshaminy Creek, Warrington Subbasin Little Neshaminy Creek, and Park Creek Basins

$[--$, not in subbasin $]$

\begin{tabular}{|c|c|c|c|c|c|c|c|}
\hline \multirow{3}{*}{ Municipality } & \multicolumn{7}{|c|}{ Subbasin and code number } \\
\hline & $\begin{array}{l}\text { West Branch } \\
\text { Neshaminy } \\
\text { Creek Basin }\end{array}$ & $\begin{array}{l}\text { Pine Run } \\
\text { Basin }\end{array}$ & $\begin{array}{l}\text { North Branch } \\
\text { Neshaminy } \\
\text { Creek Basin }\end{array}$ & $\begin{array}{l}\text { Doylestown } \\
\text { Subbasin } \\
\text { Neshaminy } \\
\text { Creek }\end{array}$ & $\begin{array}{c}\text { Warwick } \\
\text { Subbasin } \\
\text { Neshaminy } \\
\text { Creek }\end{array}$ & $\begin{array}{c}\text { Warrington } \\
\text { Subbasin Little } \\
\text { Neshaminy } \\
\text { Creek }\end{array}$ & $\begin{array}{l}\text { Park Creek } \\
\text { Basin }\end{array}$ \\
\hline & 01 & 02 & 03 & 04 & 05 & 06 & 07 \\
\hline Buckingham Township & -- & 11.5 & -- & 1.1 & 11.3 & -- & -- \\
\hline Chalfont Borough & 40.1 & 8.5 & 40.1 & 11.3 & -- & -- & -- \\
\hline Doylestown Borough & -- & 2.0 & -- & 52.2 & 45.9 & -- & -- \\
\hline Doylestown Township & -- & 20.3 & 0.3 & 42.7 & 36.5 & -- & -- \\
\hline Franconia Township & 1.5 & -- & -- & -- & -- & -- & -- \\
\hline Hatfield Borough & 97.7 & -- & -- & -- & -- & -- & -- \\
\hline Hatfield Township & 79.0 & -- & -- & -- & -- & -- & -- \\
\hline Hilltown Township & 21.4 & -- & 9.4 & -- & -- & -- & -- \\
\hline Horsham Township & -- & -- & -- & -- & -- & 13.1 & 49.7 \\
\hline Lansdale Borough & 46.9 & -- & -- & -- & -- & -- & -- \\
\hline Lower Gwynedd Township & -- & -- & -- & -- & -- & -- & 10.7 \\
\hline Montgomery Township & 27.1 & -- & -- & 6 & -- & 45.3 & 10.8 \\
\hline New Britian Borough & -- & 32.1 & -- & 68.0 & -- & -- & -- \\
\hline New Britian Township & 34.3 & 6.7 & 51.3 & 7.4 & -- & .3 & -- \\
\hline Plumstead Township & -- & 11.2 & 32.5 & -- & -- & -- & -- \\
\hline Upper Dublin Township & -- & -- & -- & -- & -- & -- & 5.3 \\
\hline Warrington Township & -- & -- & -- & 37.1 & 11.5 & 31.3 & 1.0 \\
\hline Warwick Township & -- & -- & -- & -- & 58.8 & -- & -- \\
\hline Wrightstown Township & -- & -- & -- & -- & 3.9 & -- & -- \\
\hline
\end{tabular}

assumed per capita yearly water use of $21,900 \mathrm{gal} / \mathrm{yr}$, or $60 \mathrm{gal} / \mathrm{d}$ per person, to estimate total annual areally distributed domestic ground-water usage for each subbasin (Delaware River Basin Commission, written commun., 1993).

The output report includes a list of imports and exports of wastewater from basin to basin. Imports with a use code of wastewater discharge (DIM) are listed and summed. If exports have a use code of wastewater discharge (DEX), have a source basin (BASIN_SOR) code of outside the user-selected subbasin, and have the destination basin (BASIN_DEST) code of the user-selected subbasin, the exports also are listed as wastewater-discharge imports in the report. For example, if the userspecified basin is Newtown Creek Basin (basin code 11) and a wastewater-discharge export (DEX) has a source basin (BASIN_SOR) code of outside Newtown Creek Basin (BASIN_SOR not equal to 11) and the wastewater discharge has a destination basin (BASIN_DEST) code equal to Newtown Creek, the wastewater export is listed as an import of wastewater discharge in the report. Exports with use codes of wastewater discharge (DEX) are listed and summed for the selected basin. A 10-percent annual average consumptive loss was assumed for all imports and exports of wastewater unless reported data were available (Delaware River Basin Commission, written commun., 1994).

The output report includes a list of imports and exports of water supply from basin to basin. Imports with a use code of water supply (WSI) are listed and summed. If exports have a use code of water supply (WSE), have a source basin (BASIN_SOR) code of 
Table 10. Areal percentages of townships and boroughs in Warminster Subbasin Little Neshaminy Creek, Mill Creek, Northampton Subbasin Neshaminy Creek, Newtown Creek, Core Creek, Ironworks Creek, and Lower Section Subbasin Neshaminy Creek

$[--$, not in subbasin $]$

\begin{tabular}{|c|c|c|c|c|c|c|c|}
\hline \multirow{3}{*}{ Municipality } & \multicolumn{7}{|c|}{ Subbasin and code number } \\
\hline & $\begin{array}{l}\text { Warminster } \\
\text { Subbasin } \\
\text { Little } \\
\text { Neshaminy } \\
\text { Creek }\end{array}$ & $\begin{array}{l}\text { Mill Creek } \\
\text { Basin }\end{array}$ & $\begin{array}{c}\text { Northampto } \\
\text { n Subbasin } \\
\text { Neshaminy } \\
\text { Creek }\end{array}$ & $\begin{array}{l}\text { Newtown } \\
\text { Creek }\end{array}$ & $\begin{array}{c}\text { Core Creek } \\
\text { Basin }\end{array}$ & $\begin{array}{l}\text { Ironworks } \\
\text { Creek } \\
\text { Basin }\end{array}$ & $\begin{array}{c}\text { Lower } \\
\text { Section } \\
\text { Subbasin } \\
\text { Neshaminy } \\
\text { Creek }\end{array}$ \\
\hline & 08 & 09 & 10 & 11 & 12 & 13 & 14 \\
\hline Bensalem Township & -- & -- & -- & -- & -- & -- & 58.6 \\
\hline Bristol Township & -- & -- & -- & -- & -- & -- & 25.1 \\
\hline Buckingham Township & -- & 53.7 & -- & -- & -- & -- & -- \\
\hline Doylestown Township & -- & .1 & -- & -- & -- & -- & -- \\
\hline Horsham Township & 2.8 & -- & -- & -- & -- & -- & -- \\
\hline Hulmeville Borough & -- & -- & -- & -- & -- & -- & 100.0 \\
\hline Ivyland Borough & 100.0 & -- & -- & -- & -- & -- & -- \\
\hline Langhorne Borough & -- & -- & -- & -- & -- & -- & 63.5 \\
\hline Lower Makefield Township & -- & -- & -- & -- & 17.7 & -- & -- \\
\hline Lower Moreland Township & -- & -- & -- & -- & -- & -- & 2.4 \\
\hline Lower Southampton Township & -- & -- & -- & -- & -- & -- & 55.0 \\
\hline Middletown Township & -- & -- & -- & 1.0 & 19.2 & -- & 25.0 \\
\hline Newtown Borough & -- & -- & -- & 100.0 & -- & -- & -- \\
\hline Newtown Township & -- & -- & 30.4 & 43.5 & 23.3 & -- & -- \\
\hline Northampton Township & 23.9 & -- & 21.4 & -- & -- & 24.1 & 26.9 \\
\hline Penndale Borough & -- & -- & -- & -- & -- & -- & 84.8 \\
\hline Solebury Township & -- & 2.1 & -- & -- & -- & -- & -- \\
\hline Upper Makefield Township & -- & -- & -- & -- & .1 & -- & -- \\
\hline Upper Southampton Township & -- & -- & -- & -- & -- & -- & 71.0 \\
\hline Warminster Township & 53.4 & -- & -- & -- & -- & -- & 6 \\
\hline Warrington Township & 19.0 & -- & -- & -- & -- & -- & -- \\
\hline Warwick Township & 41.2 & -- & -- & -- & -- & -- & -- \\
\hline Wrightstown Township & -- & 34.9 & 34.1 & 3.4 & -- & -- & -- \\
\hline
\end{tabular}

outside the selected subbasin, and have the destination basin (BASIN_DEST) code of the selected subbasin, the exports also are listed as water-supply imports in the report. For example, if the user-specified basin is Core Creek Basin (basin code 12) and the water-supply export (WSE) has a source basin (BASIN_SOR) code of outside Core Creek Basin (BASIN_SOR not equal to 12) and the water supply has a destination basin (BASIN_DEST) code equal to Core Creek, the water-supply export is listed as an import of water supply in the report. Exports with use codes of water supply (WSE) are listed and summed for the selected basin.
The output report includes estimates of evaporative loss and consumptive use from product incorporation. The average annual evaporative losses were estimated to be 10 percent of a purveyor's total withdrawal (Delaware River Basin Commission, written commun., 1994). The consumptive uses from product incorporation were reported by the manufacturers.

The output report includes a list of industrial septic-system discharges to ground water. A 10-percent average annual loss of the purveyor's total septic-system discharge was assumed and subtracted from the reported total septic-system discharge. The adjusted total septic-system discharge was entered into 
the data tables (Delaware River Basin Commission, written commun., 1994).

The output report includes a list of individual well allocations assigned by the DRBC. The DRBC individual well allocations are based on a 30-day period. The total of the individual allocations for a subbasin was normalized to an annual basis by multiplying by 12.167 .

\section{Program Options}

The water-management program is started from the dBASE IV dot prompt with the command DO MASTERPR. A banner is displayed, and the user is prompted to press the enter key. The main menu is displayed, and the user may select one of the following options by highlighting the selection with the arrow keys and pressing enter:

Input or Edit/Update Data Programs

Data Retrieval Programs

Annual Water-Use Calculation Program

Quit and Return to DOS

If the program displays an error message during execution, type:

\section{CLEAR ALL <ENTER> DO MASTERPR <ENTER>}

These commands will restart the program.

\section{Input and Edit or Update Data}

This option is selected for inputting, editing, or updating data in the three data tables. When this option is chosen, the input and edit/update data submenu is displayed, and the user may select one of the following options by highlighting the selection with the arrow keys and pressing enter:

Enter Data for a New Purveyor

Edit/Update Data for Existing User

USERFILE Data

WATERUSE Data

ALOCation Data

Enter New Data for Existing Purveyors
WATERUSE Data

ALOCation Data

\section{Exit and Return to MAIN MENU}

\section{Entering Data for a New Purveyor}

When the user selects this option, an input form is displayed that enables the user to enter a new purveyor into the USERFILE data table. Mandatory fields PURV_NAME, PURV_CODE, PURV_ID, and TYPE_USE must be entered. Data table integrity will be compromised and improper relational operations will result in program errors if these fields are empty. A message displayed at the bottom of the screen indicates the mandatory fields.

After the USERFILE data are entered, the user is prompted to select the first letter from the following options:

Continue to enter WATERUSE information for the new purveyor

Modify the current record just entered

Delete the current record just entered and return to the main menu

Save the record and return to the main menu

When the Continue option is chosen, an input form is displayed to enter new WATERUSE data. The mandatory fields associated with the new purveyor are automatically inserted into the input form, and reentering these fields is not required. The user then inputs the year and annual and monthly water-use totals to the WATERUSE data table.

After the WATERUSE data are entered, the user is prompted to select the first letter from the following options:

Continue to enter Allocation data

Add another year of data

Modify the record just entered

Delete the record just entered and return to the main menu

Save the record and return to the main menu

When the Continue option is chosen, an input form is displayed to enter allocation data for the WATERUSE record just entered. The mandatory fields are automatically inserted into the input form. The user adds the individual allocation, the joint 
allocation, and the system allocation data for the WATERUSE record.

After the allocation data are entered, the user is prompted to select the first letter from the following options:

Modify the record just entered

Delete the record just entered and return to the main menu

Save the record and return to the main menu

\section{Editing and Updating Data for an Existing Purveyor}

Three submenu options allow the user to edit any one of the three data tables, USERFILE, WATERUSE, and ALOCation. Once the desired option is selected, the user is prompted for the purveyor's six-digit code number, which must be supplied. If the entered code does not exist, an error message window is displayed, prompting the user to re-enter the code.

The program scans and lists certain fields for all records associated with the entered purveyor code. If the USERFILE data table is being edited, the PURV_ID, TYPE_USE, LOC_LAT, LOC_LONG, and DRBC_DOC fields are listed on the screen. If the WATERUSE data table is being edited, the PURV_ID, TYPE_USE, ANN_YEAR, and ANNUAL_TOT fields are listed on the screen. If the ALOC data table is being edited, the PURV_ID, ALLOCATION, JT_ALLOC, and SYS_ALLOC fields are listed on the screen. If more than 20 records are available for a particular purveyor, the listing stops after each 20 records, and the user is required to press any key to continue. The records on the each screen should be carefully examined for the desired data because the program does not include a screen-scrolling function.

The user is prompted to enter the PURV_ID of the record to be edited or updated. The entered PURV_ID must be in upper case or the error message "Please Turn the CAPS Lock ON" will be displayed. If the entered PURV_ID does not exist, an error message window is displayed, prompting the user to re-enter the id. When the correct PURV_ID is entered, an editing form is displayed with the data in the proper fields. The user may either press the <ENTER> key or the $\langle\mathrm{TAB}\rangle$ key to skip a field. The user types over the existing data to change the data. Unnecessary characters are erased from the data field by spacing over them. On completion of editing, the main menu is displayed.

\section{Entering New Data for an Existing Purveyor}

Two submenu options allow the user to enter new data into the WATERUSE or ALOCation data table. The user may add records to the WATERUSE data table, such as new wells, or may add records to the ALOCation data table, such as recently permitted allocations for wells. If the selection is made to add records to the WATERUSE data table, the user is prompted to enter the purveyor's six-digit code number. If the entered code does not exist, an error message window is displayed, prompting the user to re-enter the code. After a valid purveyor code is entered, an input screen is displayed to enter data into the WATERUSE data table. The PURV_CODE is the only field supplied to the user; all other mandatory fields must be entered.

After the WATERUSE data are entered, the user is prompted to select the first letter from the following options:
Continue to enter Allocation data
Add another year of data for the same purveyor id
Modify the record just entered
Delete the record just entered and return to the main menu
Save the record and return to the main menu

When the Continue option is chosen, an input form is displayed to enter allocation data for the WATERUSE record just entered. The mandatory fields are automatically inserted into the input form. The user adds the individual allocation, the joint allocation, and the system allocation data to the WATERUSE record.

If the selection is made to add records to the allocation data table, the user is prompted to enter a purveyor code. If the entered code does not exist, an error message window is displayed, prompting the user to re-enter the code. The program scans and lists certain fields for all records associated with the entered purveyor code. The fields listed are PURV_ID, TYPE_USE, ANN_YEAR, and ANNUAL_TOT. If more than 20 records are available for a particular purveyor, the listing stops after each 20 records, and the user is required to press any key to 
continue. The records on each screen should be carefully examined for the desired data because the program does not include a screen-scrolling function.

The user is prompted to enter the PURV_ID for which allocation data are to be added. The entered PURV_ID must be in upper case or the error message "Please Turn the CAPS Lock ON" will be displayed. If the entered PURV_ID does not exist, an error message window is displayed, prompting the user to re-enter the id. After the correct PURV_ID is entered, an input form is displayed for entering the new allocation data. The mandatory fields are automatically inserted into the input form. After the allocation data are entered, the user is prompted to select the first letter from the following options:

Modify the record just entered

Delete the record just entered and return to the main menu

Save the record and return to the main menu

\section{Data Retrieval Programs}

This option is selected for retrieving data from all three data tables in user-specified formats. After choosing this option, the Data Retrieval submenu is displayed, and the user may select one of the following options by highlighting the selection with the arrow keys and pressing enter:

\section{Retrieve all Data for a Purveyor \\ Retrieve all Data for a Basin or Subbasin \\ Retrieve GIS Mapping Output \\ Exit and Return to MAIN MENU}

\section{Retrieve All Data for a Purveyor}

When the user selects this option, the user is prompted for an output destination, either a file, a line printer, or a laser printer. The user is then prompted for the purveyor's six-digit code number. If the entered code does not exist, an error message window is displayed, prompting the user to re-enter the code. After a valid code is entered, all data from the three data tables for the selected purveyor are written to the selected output destination in the format as shown in table 11. After execution of the program, the user is returned to the main menu.

\section{Retrieve All Data for a Basin or Subbasin}

When the user selects this retrieval option, the user is prompted to select an output destination, either a file, a line printer, or a laser printer. The user is then prompted for a two-digit basin code, in which, the leading zero must be included (table 5). The output for the selected basin or subbasin of purveyor code, purveyor name, purveyor identifier, type of use, year of data, and annual usage or discharge amount in million gallons per year are written to the selected destination as shown in table 12. After execution of the program, the user is returned to the main menu.

\section{Retrieve Data for GIS Coverage Creation}

When the user selects the "retrieve GIS mapping output" option, the user is prompted for a type of use category (table 2). The entered type of use must be in upper case or the error message "Please Turn the CAPS Lock ON" will be displayed. The user is then prompted for a filename (eight characters or less), which will be assigned a .TXT extension. The selected type of use data are retrieved for the entire Neshaminy Creek Basin. The output file is an ASCII format file that contains these fields in the following order: LOC_LONG, LOC_LAT, PURV_ID, TYPE_USE, ANN_YEAR, and ANNUAL_TOT as shown in table 13. This file can be used to generate point coverages in a GIS. After execution of the program, the user is returned to the data retrieval submenu.

\section{Annual Water-Use Calculation Program}

This option produces an annual water-use analysis report for a user-specified basin or subbasin. Water-use activities listed and totaled are public supply; a combination of industrial, commercial, institutional, irrigation-supplied ground-water withdrawals; spray irrigation systems; surface-water withdrawals; sewage-treatment-plant discharges; imports and exports of wastewater across basin or subbasin divides; imports and exports of water supply across basin or subbasin divides; estimated evaporative loss and consumptive use from product incorporation; industrial septic system discharges; and individual, joint, and system allocations. The totals are for a user-specified year. If no data for the specified year are available, the program retrieves the most recent data available for the analysis. The 
Table 11. Output template for the retrieval of all data for a purveyor option

[\#, represents numeric data; @, represents character data]

\begin{tabular}{|c|c|c|}
\hline \multirow[b]{2}{*}{ User code -- \#\#\#\#\# } & Neshaminy Creek water-use analysis program & \multirow[b]{2}{*}{ User name -- USER NAME } \\
\hline & $\begin{array}{l}\text { Purveyor identification field } \\
\text { ID }\end{array}$ & \\
\hline Type of use & Longitude & $\begin{array}{c}\text { Zone } 18 \\
\text { UTM-X UTM-Y }\end{array}$ \\
\hline @@@ & \#\#\#\#\#\# & \#\#\#\#\#\# \#\#\#\#\#\#\#\# \\
\hline $\begin{array}{l}\text { Geologic Unit Code } \\
\text { (if applicable) }\end{array}$ & & $\begin{array}{l}\text { USGS Local Well Number } \\
\text { (if applicable) }\end{array}$ \\
\hline \#\#\#@@@@ & & @@-\#\#\#\# \\
\hline Source Basin & Source Stream Code & Source River Mile \\
\hline$\#$ & \#\#\#\# & \#.\#\# \\
\hline Destination Basin & Destination Stream Code & Destination River Mile \\
\hline \multirow[t]{2}{*}{ \#\# } & \#\#\#\#\# & \#.\#\# \\
\hline & $\begin{array}{c}\text { Delaware River Basin Commission Docket Number: } \\
\text { D\#\#-\#\#@@ }\end{array}$ & \\
\hline \multirow[t]{2}{*}{ Year of Data --> \#\# } & & ANNUAL TOTAL -->\#.\#\#\#\# \\
\hline & ALLOCATIONS & \\
\hline \multirow[t]{2}{*}{ Individual Allocation --> \#.\#\#\# } & & Joint Allocation --> \#.\#\#\#\# \\
\hline & System Allocation -->\#.\#\#\#\# & \\
\hline
\end{tabular}

program also makes comparisons between

withdrawals, ground-water contributions to base flow, and allocations. Ground-water contributions to base flow are determined for the user-specified base-flow recurrence interval and compared to the total ground-water withdrawals from public supply, industrial, commercial, institutional, irrigation wells, and spray irrigation systems. Ground-water contributions to base flow and ground-water withdrawals also are compared to the basin annual total allocations. A complete water-use analysis report for Little Neshaminy Creek, Warminster Subbasin is included in Appendix 4.

When the user selects the annual water-use calculation option, a submenu is displayed and the user may select one of the following basin or subbasin options by highlighting the selection with the arrow keys and pressing enter:

\section{Neshaminy Creek Mainstem Subbasins Doylestown Subbasin Warwick Subbasin}

Northampton Subbasin

Lower Neshaminy Subbasin

Neshaminy Creek Tributary Basins

West Branch

North Branch

Pine Run

Mill Creek

Newtown Creek

Core Creek

Ironworks Creek

Little Neshaminy Creek Subbasins and

Tributary
Warrington Subbasin
Warminster Subbasin
Park Creek

Quit and Return to MAIN MENU

After a basin or subbasin is selected, the recurrence interval comparison submenu is displayed, and the user may select one of the following by 
Table 12. Example of retrieval of all data for a basin or subbasin

[Mgal/yr, million gallons per year]

\begin{tabular}{|c|c|c|c|c|c|}
\hline \multicolumn{6}{|c|}{ Neshaminy Creek Water-Use Analysis Program } \\
\hline \multicolumn{6}{|c|}{$\begin{array}{c}\text { Neshaminy Creek Water-Use Analysis Program } \\
\text { BASIN SUMMARY } \\
01 / 12 / 95\end{array}$} \\
\hline \multicolumn{6}{|c|}{ BASIN CODE -- 01} \\
\hline CODE & Name & Purv_ID & Type of use & Year & $\begin{array}{c}\text { Total } \\
(\mathrm{Mgal} / \mathrm{yr})\end{array}$ \\
\hline 011567 & EASTERN PRESTRESSED CONCR - PROD CONS & EPRESPCN & PRO & 88 & 0.0141 \\
\hline 011567 & EASTERN PRESTRESSED CONCRET & EPRESUFT & TID & 88 & .0939 \\
\hline 011567 & EASTERN PRESTRESSED CONCR - WITH WELL & EPRESW01 & INW & 88 & .1082 \\
\hline 011569 & PORTER CHEMICAL PROCESS CO - EVAP LOSS & PORTCEVL & EVP & 88 & .0640 \\
\hline 011569 & PORTER CHEMICAL PROCESS - 2 WELLS & PORTCW01 & INW & 88 & .6400 \\
\hline 011571 & PENN COLOR INC-EVAP LOSS & PCOLOEVL & EVP & 83 & 6190 \\
\hline 011571 & PENN COLOR INC-WELL \#1 & PCOLOW01 & INW & 87 & 7.4525 \\
\hline 011571 & PENN COLOR INC-WELL \#2 & PCOLOW02 & INW & 87 & .0000 \\
\hline 011577 & BROOKS INSTRUMENT - EVAP LOSS & BROOKEVL & EVP & 88 & .8112 \\
\hline 011577 & BROOKS INSTRUMENT - NESHAMINY DISCHRG & BROOKSWD & TID & 88 & 15.0020 \\
\hline 011577 & BROOKS INSTRUMENT - WELL & BROOKW01 & INW & 88 & 15.8080 \\
\hline 011590 & M H ZEIGLER \& SONS INC - EVAP LOSS & MZEIGPCN & PRO & 88 & .1500 \\
\hline 011590 & M H ZEIGLER \& SONS INC - WITH WELL & MZEIGW01 & INW & 88 & .0000 \\
\hline 011598 & AMERICAN OLEAN TILE - EVAP LOSS & OLEANEVL & EVP & 88 & 16.6340 \\
\hline 011598 & AMERICAN OLEAN TILE - INSTREAM DISCHR & OLEANSWD & TID & 88 & 17.2900 \\
\hline 011598 & AMERICAN OLEAN TILE - WELL\#2 & OLEANW02 & INW & 82 & 5.4210 \\
\hline 011598 & AMERICAN OLEAN TILE - WELL \#3 & OLEANW03 & INW & 92 & 2.7050 \\
\hline 011598 & AMERICAN OLEAN TILE - WELL \#4 & OLEANW04 & INW & 92 & 10.2520 \\
\hline 011598 & AMERICAN OLEAN TILE - WELL \#5 & OLEANW05 & INW & 92 & 9.0590 \\
\hline 011600 & CUSTOM POOL COPING - PROD CONS & CPOOLPCN & PRO & 88 & .0022 \\
\hline
\end{tabular}

highlighting the selection with the arrow keys and pressing enter:

2-Year Recurrence Interval Contribution 5-Year Recurrence Interval Contribution 10-Year Recurrence Interval Contribution 25-Year Recurrence Interval Contribution 50-Year Recurrence Interval Contribution EXIT and return to main menu

After the user selects a recurrence interval, the user is prompted for an output destination, either a file, line printer, or laser printer. The user is then prompted with "Do you wish to continue (Y/N)". If "Y" is entered, the user must enter the year for the annual water-use analysis in two-digit format, for example,
95 for 1995 . The program executes, and the user is returned to the Main Menu. If "N" is entered, the user is returned to the Annual Water-Use Calculation Submenu.

\section{Limitations of Program}

The reliability and accuracy of the program, particularly the watershed water-use analysis program, is dependent on data integrity. Erroneous or incomplete data entered into the data tables will compromise program results. It is also important to enter the data accurately and to maintain a current database. 
Table 13. Example output for retrieval of Geographic Information System mapping option using a type of use code of Public Supply Well (PSW)

[Mgal/yr, million gallons per year]

\begin{tabular}{cclcccc}
\hline Longitude & Latitude & Purv_ID & $\begin{array}{c}\text { USGS } \\
\text { local } \\
\text { number }\end{array}$ & Type of use & Year & $\begin{array}{c}\text { Total } \\
\text { (Mgal/yr) }\end{array}$ \\
\hline 745626 & 401203 & BCWSAW04 & & PSW & 92 & 3.3470 \\
750159 & 401805 & BSVILW01 & & PSW & 91 & 1.2903 \\
750204 & 401813 & BSVILW02 & & PSW & 91 & 2.1137 \\
750354 & 401935 & BUCKTWB1 & BK-2289 & PSW & 92 & 0.6900 \\
750355 & 401935 & BUCKTWB2 & BK-2290 & PSW & 92 & 0.6900 \\
750612 & 401945 & BUCKTWF1 & & PSW & 92 & 2.7850 \\
750612 & 401945 & BUCKTWF2 & & PSW & 92 & 2.7850 \\
750534 & 402103 & BUCKTWF3 & & PSW & 92 & 6.0220 \\
750619 & 402040 & BUCWCW01 & BK-1289 & PSW & 92 & 5.1800 \\
750627 & 402058 & BUCWCW02 & BK-1290 & PSW & 92 & 0.0000 \\
750629 & 402024 & BUCWCW03 & & PSW & 92 & 0.0000 \\
750038 & 401748 & BVNURW01 & & PSW & 92 & 0.9290 \\
750036 & 401750 & BVNURW02 & & PSW & 92 & 0.9290 \\
750035 & 401750 & BVNURW03 & & PSW & 91 & 0.9290 \\
750619 & 402123 & CANTBW01 & & PSW & 91 & 1.0950 \\
750614 & 402119 & CANTBW02 & & PSW & 92 & 0.0000 \\
750807 & 402015 & CGATEW01 & & PSW & 93 & 0.0000 \\
751149 & 401734 & CHALBW08 & & PSW & 90 & 77.2830 \\
751248 & 401739 & CHALBW09 & BK-1177 & PSW & 93 & 0.0000 \\
751235 & 401747 & CHALBW11 & BK-965 & PSW & 93 & 58.4490 \\
\hline
\end{tabular}

For the comparisons of public-water supplies, industrial, commercial, and institutional supplies to ground-water contributions to base flow, the ground-water contributions were based strictly on hydrologic factors and did not take into account any environmental or economic factors.

A variable that has an effect on a basinwide water-use analysis is infiltration of ground water into public sewer systems. Infiltration was not incorporated into the watershed analysis for this study and was not included in this program. Further investigation of infiltration in the Neshaminy Creek Basin would have to be done to reliably estimate this variable. Sloto and Davis (1983) found in Warminster Township that large quantities of ground water infiltrated into the public sewer system. They calculated that $830 \mathrm{Mgal}$ of ground water infiltrated into the Warminster municipal sewage treatment system in 1979, a wet year, and $250 \mathrm{Mgal}$ infiltrated in 1980, a dry year.

\section{SUMMARY}

The Neshaminy Creek Basin is in a heavily populated area of southeastern Pennsylvania. The demand for water has increased greatly over recent years and will probably increase even more in the future. The Delaware River Basin Commission (DRBC) manages, protects, and allocates water resources in the Neshaminy Creek Basin. A water-use analysis program was developed for the Neshaminy Creek Basin to assist the DRBC in managing and allocating basin water resources. In order to effectively manage and allocate water resources in the basin, data on quantities and locations of withdrawals, discharges, and imports and exports must be current, accurate, and easily accessible. Using a common relational database-management software, the quantities and locations of withdrawals, discharges, imports, and exports were combined and stored in three data tables-a USERFILE table, a WATERUSE table, and an ALOCation table. The program allows a user to interactively input, edit, update, or retrieve data from 
these data tables and provides a watershed water-use analysis report.

The watershed water-use analysis is done geographically for a user-specified subbasin. The Neshaminy Creek Basin was divided into 14 subbasins. The water-use analysis report lists summations of public-supply well withdrawals; a combination of industrial, commercial, institutional, irrigation well withdrawals, and spray irrigation systems; surface-water withdrawals; wastewatertreatment-facility discharges; estimates of domestic ground-water withdrawals; imports and exports of wastewater; imports and exports of water supplies; evaporative loss and consumptive use from product incorporation; industrial septic-system discharges; and individual well allocations assigned by the Delaware River Basin Commission.

Ground-water contributions to base flow of each subbasin were estimated from annual base flow at the 2-, 5-, 10-, 25-, and 50-year recurrence intervals. The report lists a comparison of a user-specified base-flow recurrence-interval estimate to total ground-water withdrawals and annual total DRBC-permitted ground-water allocations.

\section{REFERENCES CITED}

Bucks County Planning Commission, 1993, Bucks County population 1930-1990: Doylestown, Pa., Data and statistical information data sheet, MP-8A, $1 \mathrm{p}$.

Longwill, S.M., and Wood, C.R., 1965, Ground-water resources of the Brunswick Formation, Montgomery and Berks Counties Pennsylvania: Pennsylvania Geological Survey, 4th ser., Water Resources Report 22, 59 p.

Lyttle, P.T., and Epstein, J.B., 1987, Geologic map of the Newark $1^{\circ} \times 2^{\circ}$ quadrangle, New Jersey, Pennsylvania, and New York: U.S. Geological Survey Miscellaneous Investigations Series I-1715, 2 plates, scale 1:250,000.

Montgomery County Planning Commission, 1993, Demographics-Montgomery County, Pa., Population Projections 2000-2020: Montgomery County Planning Commission, $1 \mathrm{p}$.

R.E. Wright Associates, Inc. [n.d.], Special groundwater study of the middle Delaware River Basin study area II: R.E. Wright Associates, Inc., v. 1, chap. 1-7.

Sloto, R.A., 1991, title, in Balthrop, B.H., and Terry, J.E., eds., U.S. Geological Survey National Computer Technology Meeting, proceedings, Phoenix, Ariz., November 14-18, 1988: U.S. Geological Survey Water-Resources Investigations Report 90-4162, p. 101-110.

Sloto, R.A., Cecil, L.D., and Senior, L.A., 1991, Hydrogeology and ground-water flow in the carbonate rocks of the Little Lehigh Creek Basin, Lehigh County, Pennsylvania: U.S. Geological Survey Water-Resources Investigations Report 90-4076, 83 p.

Sloto, R.A., and Davis, D.K., 1983, Effect of urbanization on the water resources of Warminster Township, Bucks County, Pennsylvania: U.S. Geological Survey Water-Resources Investigations Report 82-4020, 72 p.

Wood, C.R., Flippo, H.N., Jr., Lescinsky, J.B., and Barker, J.L., 1972, Water resources of Lehigh County, Pennsylvania: Pennsylvania Geological Survey, 4th ser., Water Resources Report 31, p. 263. 
APPENDIXES 


\title{
APPENDIX 1. Master Control Program
}

\section{(filename masterpr.prg)}

* Program......: MASTERPR.PRG

* Author.......: This is an APPLICATION OBJECT.

* Date.........: 1-25-94

* Revised......: 3-9-94 by CLSCHREFFLER for Neshaminy Modeling Project

* Notice.......: This program was generated using the Applications Generator.

* The file was copied from the Chester County Water Use Model

* workspace and edited for use in the Neshaminy Water Use Model.

* Generated by:: dBASE IV version 1.5

* Description.: Main routine for menu system

**** Setting up initial environment

SET BELL ON

SET CARRY OFF

SET CENTURY OFF

SET CLOCK OFF

SET CONFIRMOFF

SET DELIMTTERS TO “

SET DELIMITERS OFF

SET DEVICE TOSCREEN

SET ESCAPE ON

SET EXCLUSIVE ON

SET LOCK ON

SET MESSAGE TO “.”

SET PRINT OFF

SET REPROCESS TO 4

SET SAFETY ON

SET TALKOFF

SET SCOREBOARDOFF

*-Initialize global variables

gl_batch=.F. \&\& is a batch operation in progress

gn_error $=0 \quad \& \& 0$ if no error, otherwise an error occurred

gn_scrsize $=21 \quad \& \&$ number of lines on screen

gn_send $=0 \quad \& \&$ return value from popup of position menus

gn_trace $=1 \quad \& \&$ sets trace level, however you need to change template

gc_brdr $=^{\prime} 1^{\prime} \quad \& \&$ border to use when drawing boxes

gc $\_d e v=' \mathrm{CON}^{\prime} \quad \& \&$ Device to use for printing - See Proc. PrintSet

gl_leave=.f. \&\& leave the application

gc_prognum $=$ ' \& \&\& internal program counter to handle nested menus

gc_quit $=$ " \&\& memvar for return to caller

gc_scope $=" \quad \& \&$ scope, for and while of position at runtime

listval='NO_FIELD' \&\& Pick List value

*-Blank the screen

CLEAR

SET SCOREBOARD OFF

SET STATUSOFF

* Setting the Procedure Library

SET PROCEDURE TO proclib

\&\& Procedure Library Program Name

* Setting up the database Indexes and Areas and Declares Public Memory Variables

\author{
USE USERFILE IN 1 ORDER PURV_CODE \\ USE WATERUSE IN 3 ORDER WATMDX \\ *-WATMDX is the complex index tag name \\ USE ALOC IN 2 ORDER PURV_CODE
}

PUBLIC mvar2, mvar5, mvar10, mvar25, mvar50, mvar_recur, mrecur

PUBLIC mtitle, mavail, num, M->flag, mvar_yr, mvar_domuse, mvar_domdep

PUBLIC M->file_nam, mvar_basin 


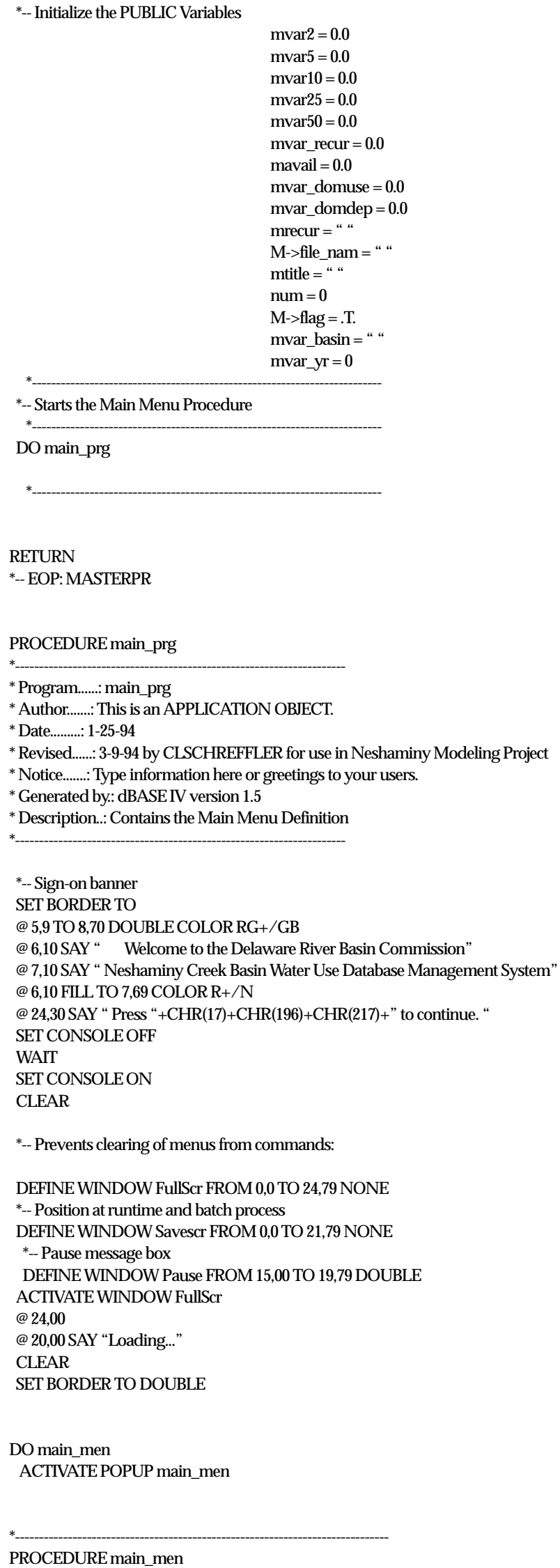


DEFINE POPUP main_men FROM 5,19 TO 14,61 ;

MESSAGE "Press first letter, or highlight choice and Press <Enter>"

DEFINE BAR 1 OF main_men PROMPT “************* MAIN MENU ${ }^{* * * * * * * * * * * * * \prime}$ SKIP

DEFINE BAR 2 OF main_men PROMPT “" $\quad$ SKIP

DEFINE BAR 3 OF main_men PROMPT “ Input or Edit/Update Data Programs”

DEFINE BAR 4 OF main_men PROMPT “ Data Retrieval Programs”

DEFINE BAR 5 OF main_men PROMPT “ Annual Water-use Calculation Program”

DEFINE BAR6 OF main_men PROMPT “ Quit and Return to DOS"

ONSELECTION POPUP main_men DO main

SET BORDER TODOUBLE

SET COLOR OF HIGHLIGHT TO R+

RETURN

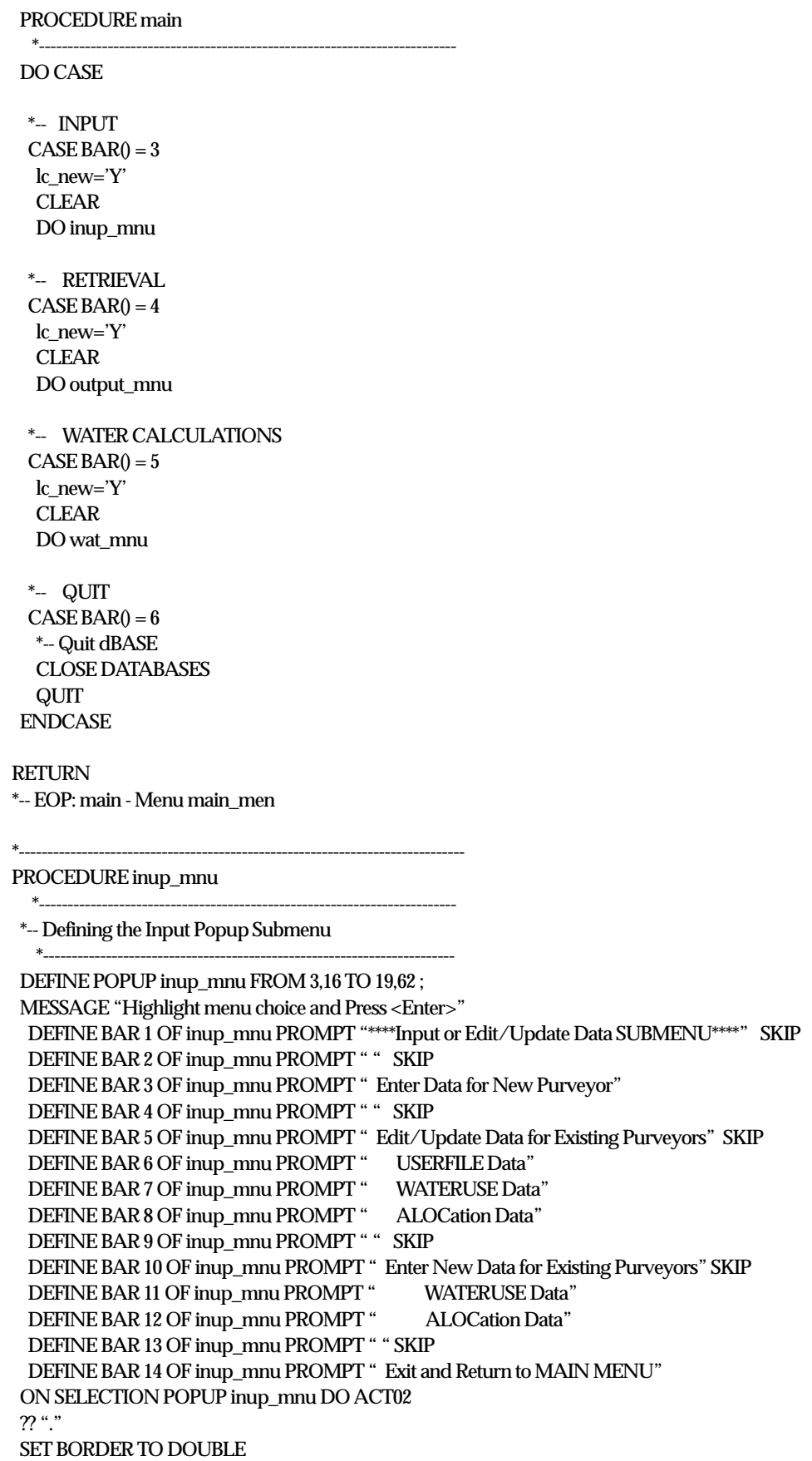




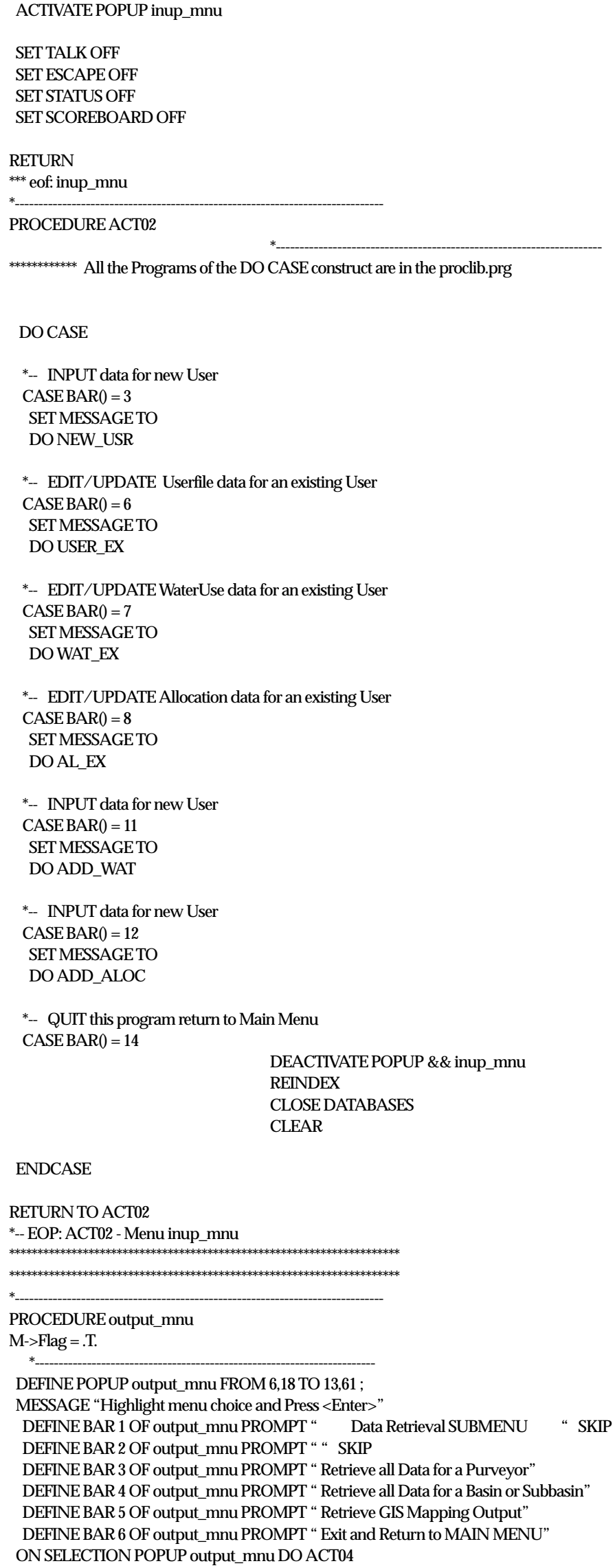


??"."

SET BORDER TODOUBLE

ACTIVATE POPUP output_mnu

SET TALKOFF

SET ESCAPEOFF

SET STATUS OFF

SET SCOREBOARDOFF

RETURN

*** eof: output_mnu

PROCEDURE ACT04

DOCASE \&\& Programs of the DOCASE construct are in the Proclib.prg

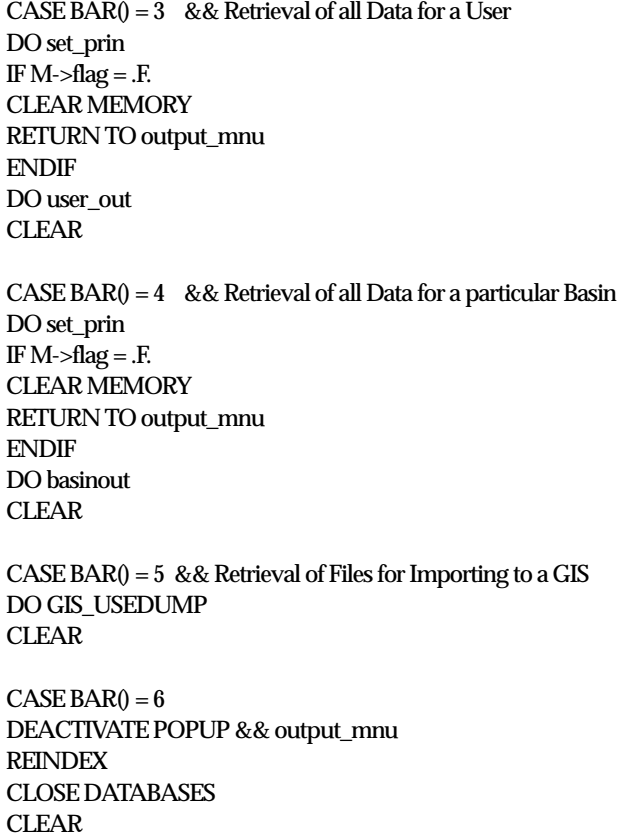

PROCEDURE wat_mnu

*-Defining the Water Calculation Popup Submenu

DEFINE POPUP wat_mnu FROM 0,16 TO 24,65 MESSAGE "Highlight Selection "

DEFINE BAR 1 OF wat_mnu PROMPT “ Annual Water Calculation SUBMENU” SKIP DEFINE BAR 2OF wat mnu PROMPT " "SKIP

DEFINE BAR 3 OF wat_mnu PROMPT “ Neshaminy Creek Main Stem Subbasins” SKIP

DEFINE BAR 4 OF wat mnu PROMPT “ Doylestown Subbasin"

DEFINE BAR 5 OF wat_mnu PROMPT “ Warwick Subbasin”

DEFINE BAR 6 OF wat_mnu PROMPT " Northampton Subbasin"

DEFINE BAR 7 OF wat_mnu PROMPT “ Lower Neshaminy Subbasin”

DEFINE BAR 8 OF wat mnu PROMPT " "SKIP

DEFINE BAR 9 OF wat_mnu PROMPT “ Neshaminy Creek Tributary Basins" SKIP

DEFINE BAR 10 OF wat_mnu PROMPT “ West Branch"

DEFINE BAR 11 OF wat mnu PROMPT " North Branch"

DEFINE BAR 12 OF wat_mnu PROMPT “ Pine Run”

DEFINE BAR 13 OF wat_mnu PROMPT “ Mill Creek"

DEFINE BAR 14 OF wat_mnu PROMPT “ Newtown Creek”

DEFINE BAR 15OF wat_mnu PROMPT “ Core Creek"

DEFINE BAR 16 OF wat_mnu PROMPT “ Ironworks Creek”

DEFINE BAR 17 OF wat mnu PROMPT " "SKIP

DEFINE BAR 18 OF wat_mnu PROMPT “ Little Neshaminy Creek Subbasins and Tributary” SKIP 


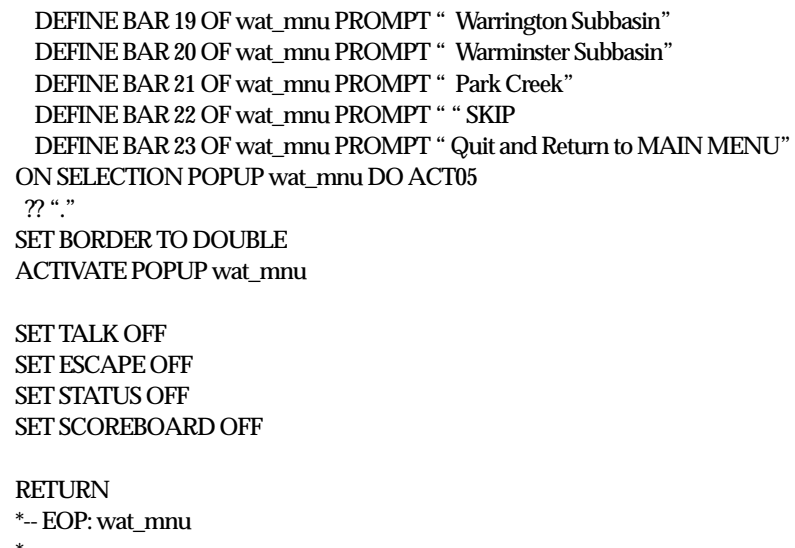


CASE BAR() $=06 \quad \& \&$ Northampton Subbasin Neshaminy Creek

STORE "Northampton Subbasin Neshaminy Creek " to mtitle \&\& Storing Watershed

\&\& name to variable mtitle

mvar_basin = ' 10 ' \&\& Setting Memory variable for the selected basin

mvar2 $=6.039993 * 365 \quad \& \&$ Setting Memory variables for Basin

mvar5 $=4.103842 * 365 \quad \& \&$ yields at the different recurrence

mvar10 $=3.404402 * 365 \& \&$ intervals.

$\operatorname{mvar} 25=2.17547 * 365$

mvar50 $=1.912946 * 365$

mvar_domuse $=.237189 * 365$

mvar_domdep $=$ mvar_domuse $* 0.2$

DO freq_mnu

IF M->flag $=$.F.

CLEAR MEMORY

RETURN TO ACT05

ENDIF

DO set_prin

IFM->flag $=$.F.

CLEAR MEMORY

RETURN TO ACT05

ENDIF

DO continue

CASE BAR ()$=07 \quad \& \&$ Lower Neshaminy Subbasin Neshaminy Creek

STORE " Lower Neshaminy Subbasin Neshaminy Creek " to mtitle \&\& Storing Watershed

\&\& name to variable mtitle

mvar basin $=$ ' 14 ' \&\& Setting Memory variable for the selected basin

mvar2 $=17.18292 * 365 \quad \& \&$ Setting Memory variables for Basin

mvar5 $=11.78435 * 365 \quad \& \&$ yields at the different recurrence

mvar10 $=9.669911 * 365 \& \&$ intervals.

$\operatorname{mvar} 25=7.631331 * 365$

mvar50 $=5.618718 * 365$

mvar_domuse $=.363868 * 365$

mvar_domdep $=$ mvar_domuse ${ }^{*} 0.2$

DO freq_mnu

IF M- $>$ flag $=$.F.

CLEAR MEMORY

RETURN TO ACT05

ENDIF

DO set_prin

IFM->flag $=$.F.

CLEAR MEMORY

RETURN TO ACT05

ENDIF

DO continue

CASE BAR() $=10 \quad \& \&$ West Branch Neshaminy Creek

STORE "West Branch Neshaminy Creek " to mtitle \&\&Storing Watershed

\&\& name to variable mitle

mvar basin $=$ '01' \&\& Setting Memory variable for the selected basin

mvar $2=7.895241 * 365 \quad \& \&$ Setting Memory variables for Basin

mvar5 $=6.039354 * 365 \quad \& \&$ yields at the different recurrence

mvar $10=4.730874 * 365$ \&\& intervals

$\operatorname{mvar} 25=3.848417 * 365$

$\operatorname{mvar} 50=3.595602 * 365$

mvar_domuse $=.387406 * 365$

mvar_domdep $=$ mvar_domuse $* 0.2$

DO freq_mnu

IFM->flag $=$.F.

CLEAR MEMORY

RETURN TO ACT05

ENDIF

DO set_prin

IFM- $>$ flag $=. F$.

CLEAR MEMORY

RETURN TO ACT05

ENDIF

DO continue

CASE BAR ()$=11 \quad \& \&$ North Branch Neshaminy Creek

STORE "North Branch Neshaminy Creek " to mtitle \&\& Storing Watershed

\&\& name to variable mtitle 


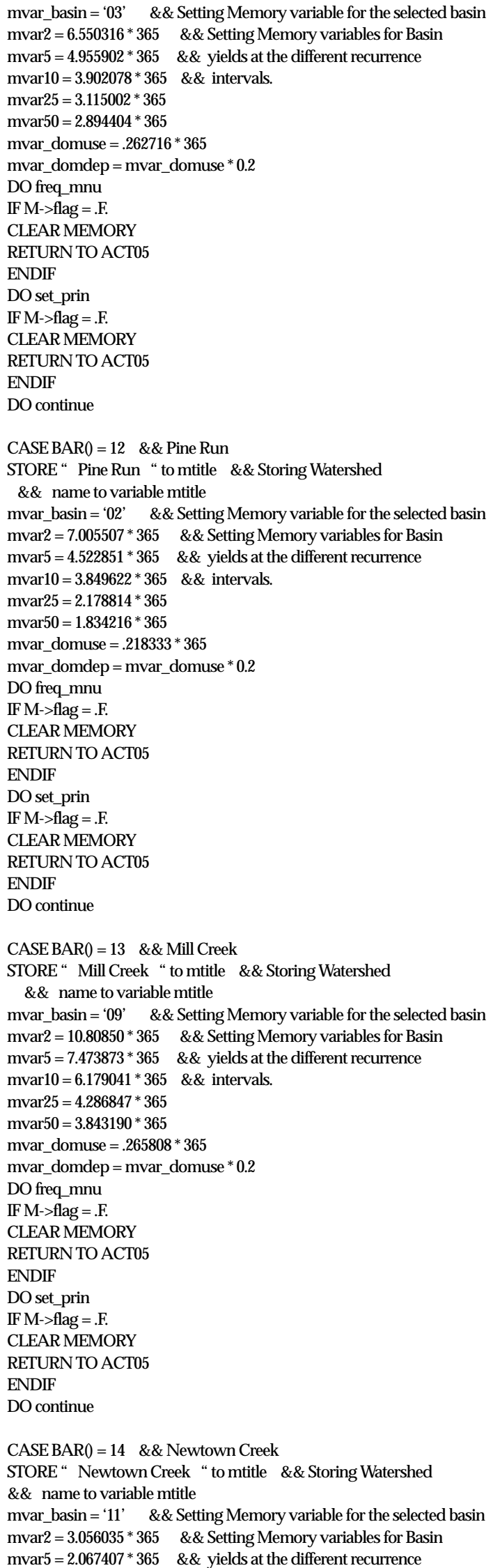




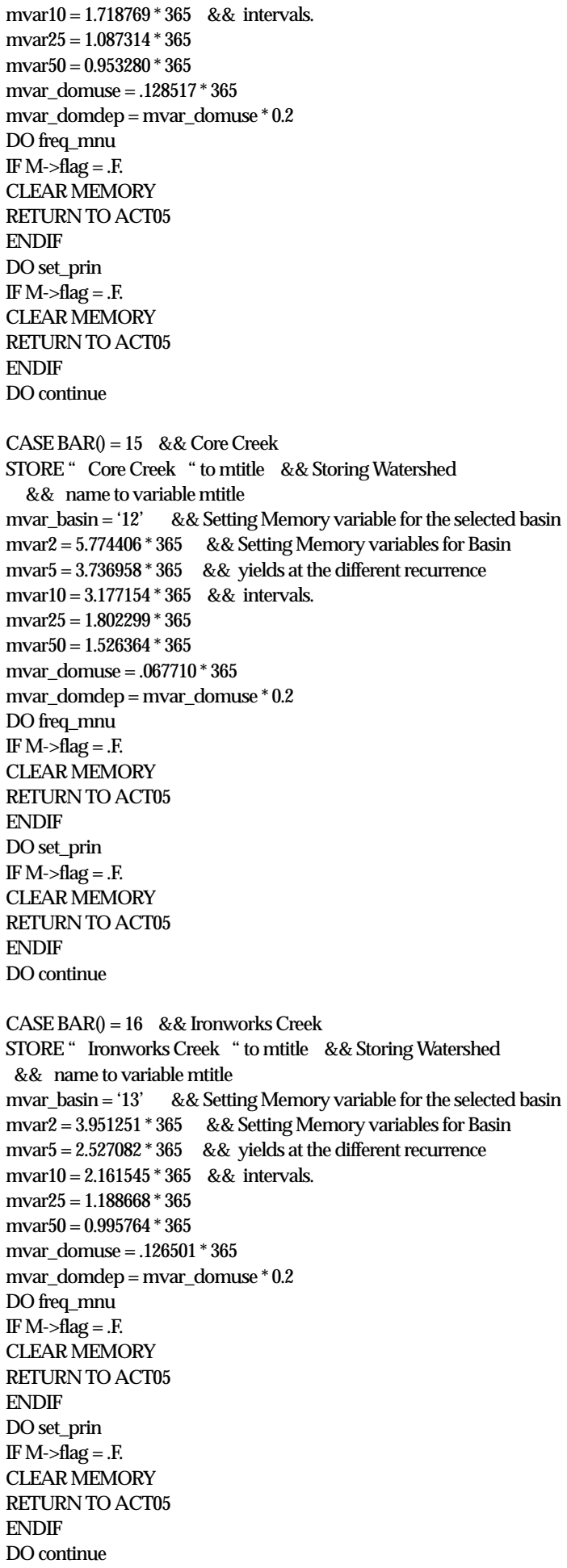




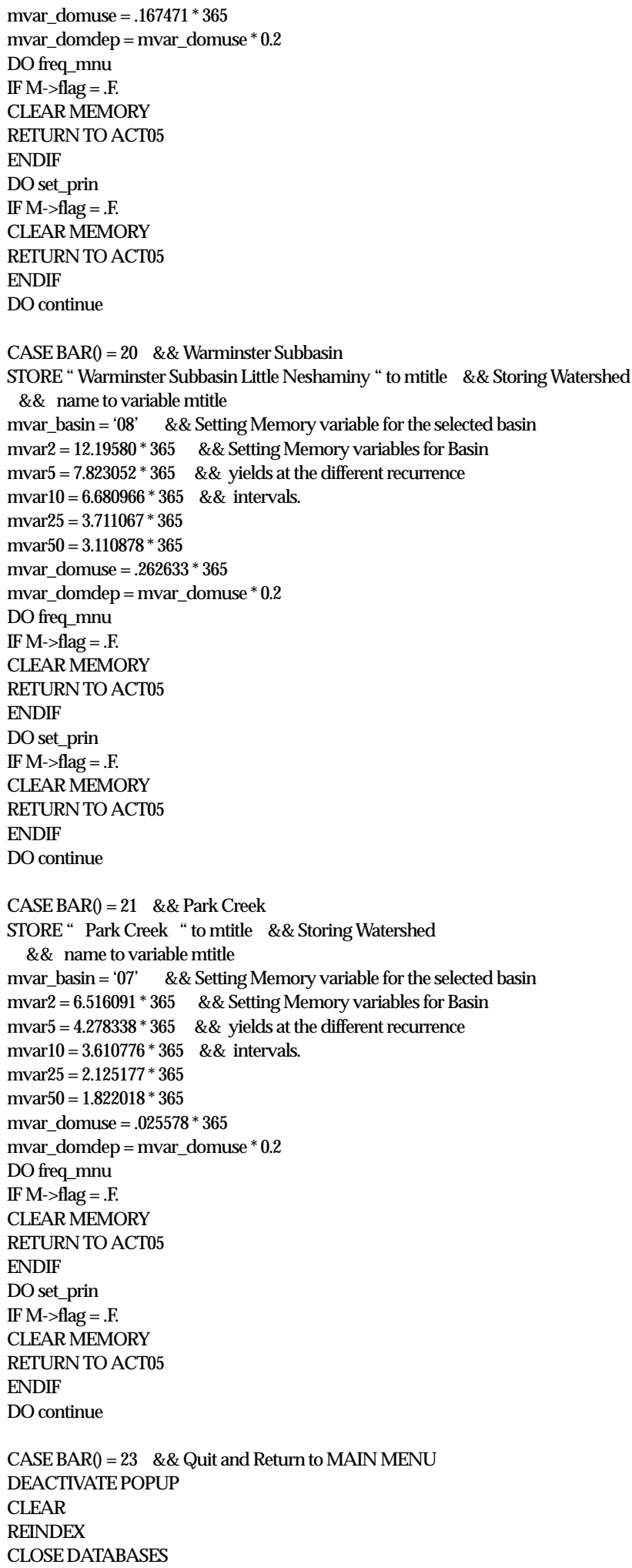

ENDCASE

RETURN TO ACT05 


\section{APPENDIX 2. Procedure Library}

\section{(filename proclib.prg)}

* This is the Process Library for all the Procedures used in the MASTERPR

* Program. The PrntRtry was created in the Applications

* Generator and copied to this Library.

*PROGRAM: GWYIELD.PRG

*DATE : NOVEMBER 13, 1987. MODIFIED JUNE 7, 1988.

*NOTES : PROGRAM CALLED FROM ANALYSIS.PRG.

* COMPARES GW WITHDRAWAL TOTALSWITH

* GW YIELDOF WATERSHED.

*AUTHOR: KAREN VOGEL

PROCEDURE GWYIELD

DOWHILE.T.

mavail $=$ mvar_recur - gwtotal

SET PRINT ON

?

? SPACE(8) + REPLICATE(" ",66)

? SPACE $(8)+$ "Comparison of Ground Water Withdrawals"

? SPACE $(8)+$ "with " + mtitle + "Watershed Ground-Water"

? SPACE $(8)+$ " contribution to base-flow for the " + mrecur

? SPACE $(8)+$ REPLICATE (“'-",66)

? SPACE(8) + "Basin Contribution (mgal) Total GW Withdrawals (mgal/yr) Difference (mgal)"

? SPACE(13) + STR(mvar_recur,10,3) + SPACE(17) + STR(gwtotal,10,3) + SPACE(16) + STR(mavail,10,3)

EJECT

SET PRINT OFF

RETURN

ENDDO

***EOF: GWYIELD.PRG

*PROGRAM: GW_COMP.PRG

*DATE : MAY 31, 1994.

*NOTES : PROGRAMCALLED FROM ANALYSIS.PRG.

* COMPARES ALLOCATION TOTALS WITH GW WITHDRAWAL TOTALS AND

* GW YIELD OF WATERSHED.

*AUTHOR: CURTIS L. SCHREFFLER

PROCEDUREGW_COMP

DOWHILE.T

malloc $=$ mvar_recur - alloc_yr

SET PRINT ON

? SPACE(8) + REPLICATE (" _,"66)

? SPACE $(8)+$ "Comparison of Allocations with Ground Water Base-flow Contribution"

? SPACE $(8)+$ " with " + mtitle + "Watershed Ground Water"

? SPACE (8) + "Contribution to Base Flow for the " + mrecur

? SPACE (8) + REPLICATE (“-",66)

? SPACE(8) + "Basin Contribution (mgal) Total Allocation (mgal) Difference (mgal)"

? SPACE(13) + STR(mvar_recur,10,3) + SPACE(17) + STR(alloc_yr,10,3) + SPACE(16) + STR(malloc,10,3)

\section{SET PRINT OFF}

malloc $=0.000$

mwith $=$ gwtotal + swtotal

malloc $=$ mwith - alloc_yr

\section{SET PRINT ON}

? SPACE(8) + REPLICATE(" ", 66)

? SPACE $(8)+$ "Comparison of Allocations with Total Ground Water/Surface Water"

? SPACE $(8)$ + "Withdrawals for " + mtitle + "Watershed" 
?SPACE(8) + REPLICATE (“-",66)

? SPACE(8) + "Total Withdrawals (mgal) Total Allocation (mgal) Difference (mgal)"

? SPACE $(13)+$ STR $($ mwith,10,3) + SPACE(17) + STR(alloc_yr,10,3) + SPACE(16) + STR(malloc,10,3)

SET PRINT OFF

RETURN

ENDDO

*** EOF: GW_COMPPRG

** The next 3 Procedure are Executed from the "inup_mnu" Option of

** adding data for a NEW user

*** NEW USR ***

*AUTHOR: CURTISSCHREFFLER

*DATE : MARCH 21, 1994

*NOTES: CALLED BY POPUP MENU inup_mnu. THIS PROCEDURE PULLS UP SCREEN FOR

* ENTERING DATA INTO THE USERFILE DATABASE FOR A NEW USER. THE

* OPERATOR MAY ALSO ENTER DATA FOR THE NEW USER IN THE WATERUSE AND

* ALOC DATABASES IF THEY DESIRE.

PROCEDURENEW_USR

DOWHILE.T.

CLEAR

SELECT 1 \&\& The USERFILE.DBF database is in Area 1.

APPENDBLANK

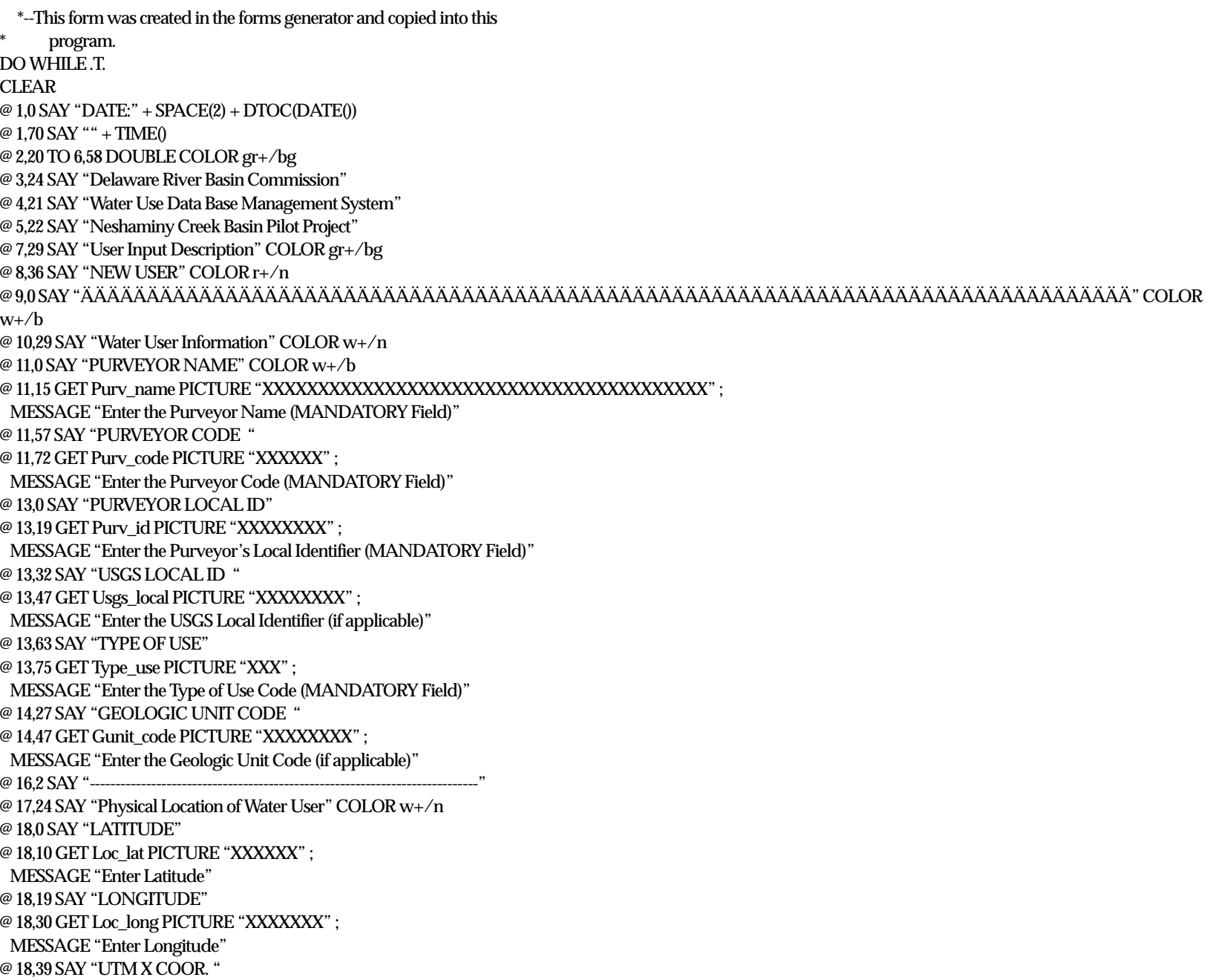


@ 18,51 GET Utm18_x PICTURE “XXXXXX” ;

MESSAGE "Enter the UTMZone_18X_Coordinate"

@ 18,60 SAY “UTM Y COOR."

@ 18,72 GET Utm18_y PICTURE "XXXXXXX” ;

MESSAGE "Enter the UTMZone_18Y_Coordinate"

@ 20,2 SAY"

@ 21,7 SAY "Basin and Stream Coding Information for the Source and Destination" COLOR w+/n

@ 22,0SAY "SOURCE BASIN CODE"

@ 22,18 GET Basin_sor PICTURE "XX" ,

MESSAGE "Enter the Source Basin"

@ 22,23 SAY "SOURCE STREAMCODE"

@ 22,42 GET Sstm_code PICTURE "XXXXXX";

MESSAGE "Enter the Pennsylvania Stream Code for the Source (if applicable)"

@ 22,51 SAY "SOURCE RIVER MILE"

@ 22,69 GET Srv_mile PICTURE “999.99”;

MESSAGE "Enter the River Mile for the Source (if applicable)"

READSAVE

IF ISBLANK(PURV_NAME).OR. ISBLANK(PURV_CODE).OR. ISBLANK(PURV ID)

DONODATA

LOOP

ENDIF

CLEAR

*-Format Page: 2

@ 2,1 SAY “New User Input Design Screen Continued"

@ 3,2SAY"

@ 4,0SAY "DESTINATION BASIN CODE"

@ 4,23 GET Basin_dest PICTURE "XX";

MESSAGE "Enter the Destination Basin"

@ 4,26SAY "DESTINATION STREAM CODE"

@ 4,50 GET Dstm_code PICTURE "XXXXXX"

MESSAGE "Enter the Pennsylvania Stream Code for the Destination (if applicable)"

@ 4,57 SAY “DEST. RIVER MILE"

@ 4,74 GET Drv_mile PICTURE “999.99";

MESSAGE "Enter the River Mile for the Destination (if applicable)"

@ 6,27 SAY "Miscellaneous Information" COLOR w+/n

@ 7,0SAY “DRBC DOCKET NUMBER "

@ 7,20 GET Drbc_doc PICTURE "XXXXXXXXXXXXXXX";

MESSAGE "Enter the DRBC Docket Number (if applicable)" READSAVE

*-The Menu at the bottom of the User Input Form

@ 9,20SAY "Press"

( 9, 9,26SAY “C" COLOR R+/N

@ 9,27 SAY " to continue to input Water Use data"

@ 10,20 SAY "Press "

@ 10,26SAY "M" COLOR R+/N

@ 10,27 SAY " to modify description just entered"

(11,20SAY "Press"

@ 11,26SAY "D" COLOR R+/N

( 11,27 SAY " to delete current record"

@ 12,20 SAY "Press"

@ 12,26SAY "R" COLOR R+/N

@ 12,27 SAY " to save current record and Return to Main Menu"

*_____ Initialize the global memory variables which may be needed

* for further data entry

gl_id = PURV_ID

gl name $=$ PURV NAME

gl_code $=$ PURV_CODE

gl_use $=$ TYPE_USE

DOWHILE.T.

M->Flag $=" “$

@ 15,20SAY" "

WAIT "PRESS Choice now : " TO M->Flag

DOCASE

CASE M->Flag $=$ "C $\mathrm{C}$. OR. M- $>$ Flag $="{ }^{\prime}$ "

DO new_wat \&\& Procedure to Enter New WATERUSE Data 


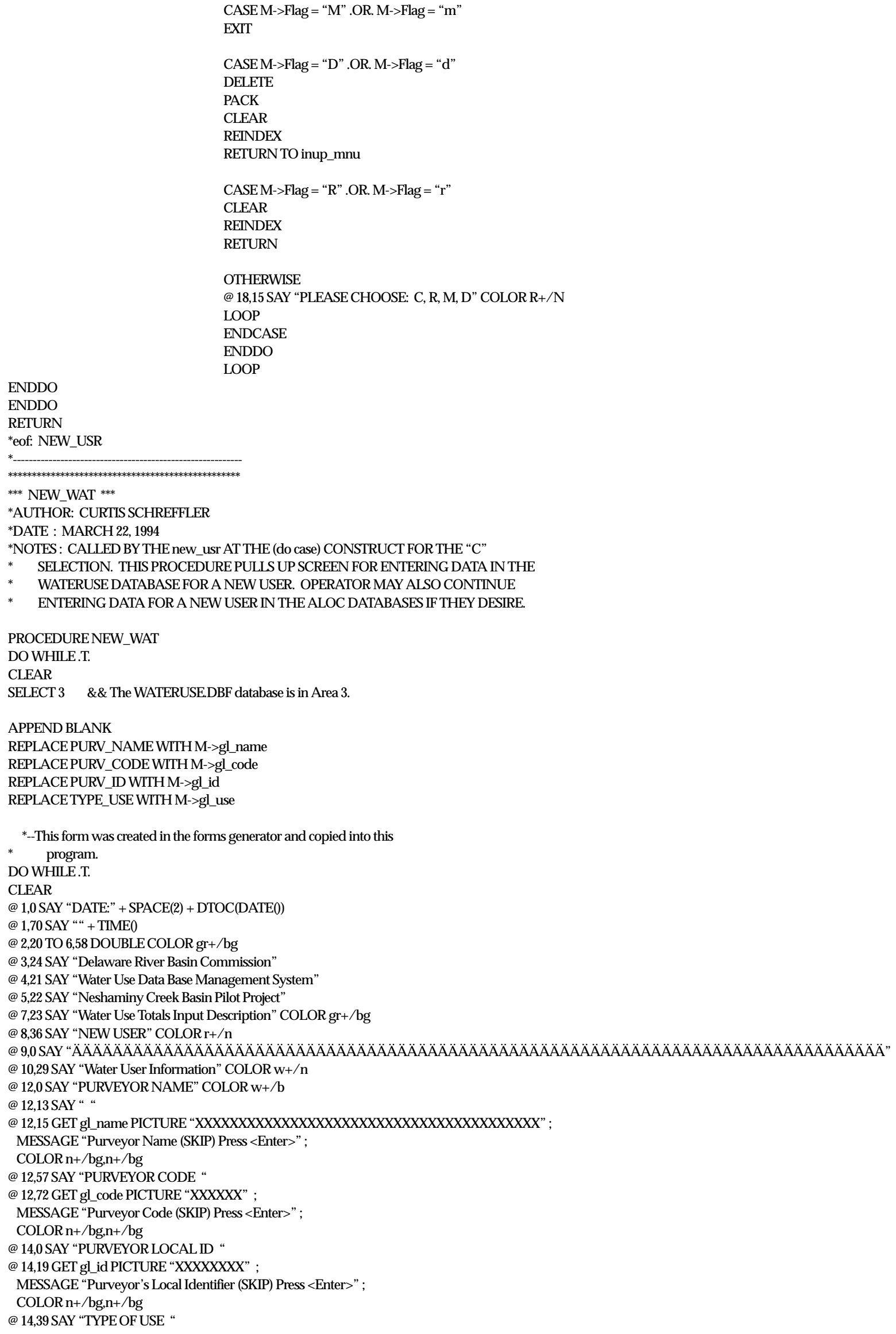

40 Water-Use Analysis Program for the Neshaminy Creek Basin, Bucks and Montgomery Counties, Pennsylvania 
@ 14,52 GET gl_use PICTURE "XXX" ;

MESSAGE "Type of Use Code (SKIP) Press <Enter>" ;

COLOR $n+/$ bg, $n+/$ bg

@ 14,70 SAY "YEAR" COLOR w+/b

@ 14,76 GET Ann_year PICTURE “XX" ;

MESSAGE "Enter the Year for which the following data apply (MANDATORY)"

@ 16,2SAY"

@ 18,22 SAY "Annual and Monthly Water Use Totals" COLOR w $+/ \mathrm{n}$

@ 20,27 SAY "ANNUAL TOTAL "

@ 20,41 GET Annual_tot PICTURE “99999.9999”;

MESSAGE "Enter the Total annual water use for the year"

@ 22,10 SAY

@ 23,0 SAY “JAN TOTAL “

@ 23,12 GET Jan_total PICTURE “99999.9999” ;

MESSAGE "Enter the Total monthly water use for January"

@ 23,29 SAY "FEB TOTAL "

@ 23,41 GET Feb_total PICTURE “99999.9999”;

MESSAGE "Enter the Total monthly water use for February"

@ 23,58 SAY "MAR TOTAL “

@ 23,70 GET Mar_total PICTURE “99999.9999" ;

MESSAGE “Enter the Total monthly water use for March"

READSAVE

CLEAR

*-Format Page: 2

@ 2,1 SAY "New Water Use Totals Input Design Screen Continued"

(a) 3,2SAY"

@ 5,0SAY "APR TOTAL"

@ 5,12 GET Apr_total PICTURE “99999.9999”

MESSAGE "Enter the Total monthly water use for April”

@ 5,29SAY "MAY TOTAL"

@ 5,41 GET May_total PICTURE “99999.9999” ;

MESSAGE "Enter the Total monthly water use for May"

@ 5,58SAY "JUN TOTAL"

@ 5,70 GET Jun_total PICTURE “99999.9999” ;

MESSAGE "Enter the Total monthly water use for June"

@ 7,0SAY "JUL TOTAL"

@ 7,12 GET Jul_total PICTURE “99999.9999” :

MESSAGE "Enter the Total monthly water use for July"

@ 7,29SAY "AUG TOTAL"

@ 7,41 GET Aug total PICTURE “99999.9999”;

MESSAGE "Enter the Total monthly water use for August"

@ 7,58SAY "SEP TOTAL"

@ 7,70 GET Sep_total PICTURE “99999.9999” ;

MESSAGE "Enter the Total monthly water use for September" @ 9,0SAY "OCT TOTAL"

@ 9,12 GET Oct_total PICTURE “99999.9999” ;

MESSAGE "Enter the Total monthly water use for October"

@ 9,29SAY "NOV TOTAL"

@ 9,41 GET Nov_total PICTURE “99999.9999”;

MESSAGE "Enter the Total monthly water use for November"

@ 9,58 SAY "DEC TOTAL"

@ 9,70 GET Dec_total PICTURE “99999.9999” ;

MESSAGE "Enter the Total monthly water use for December"

@ 10,10SAY

READSAVE

*- The Menu at the bottom of the User Input Form

@ 12,20 SAY "Press"

(a) 12,26SAY "C" COLOR R+/N

@ 12,27 SAY " to continue to input Allocation data"

@ 13,20 SAY "Press "

@ 13,26SAY "A" COLOR R+/N

@ 13,27 SAY " to Add another Year of data"

@ 14,20SAY "Press"

@ 14,26 SAY "M" COLOR R+/N

@ 14,27 SAY " to modify description just entered"

@ 15,20 SAY "Press "

@ 15,26SAY "D" COLOR R+/N

@ 15,27 SAY " to delete current record"

@ 16,20 SAY "Press"

@ 16,26SAY "R" COLOR R+/N

@ 16,27 SAY " to save current record and Return to Main Menu" 


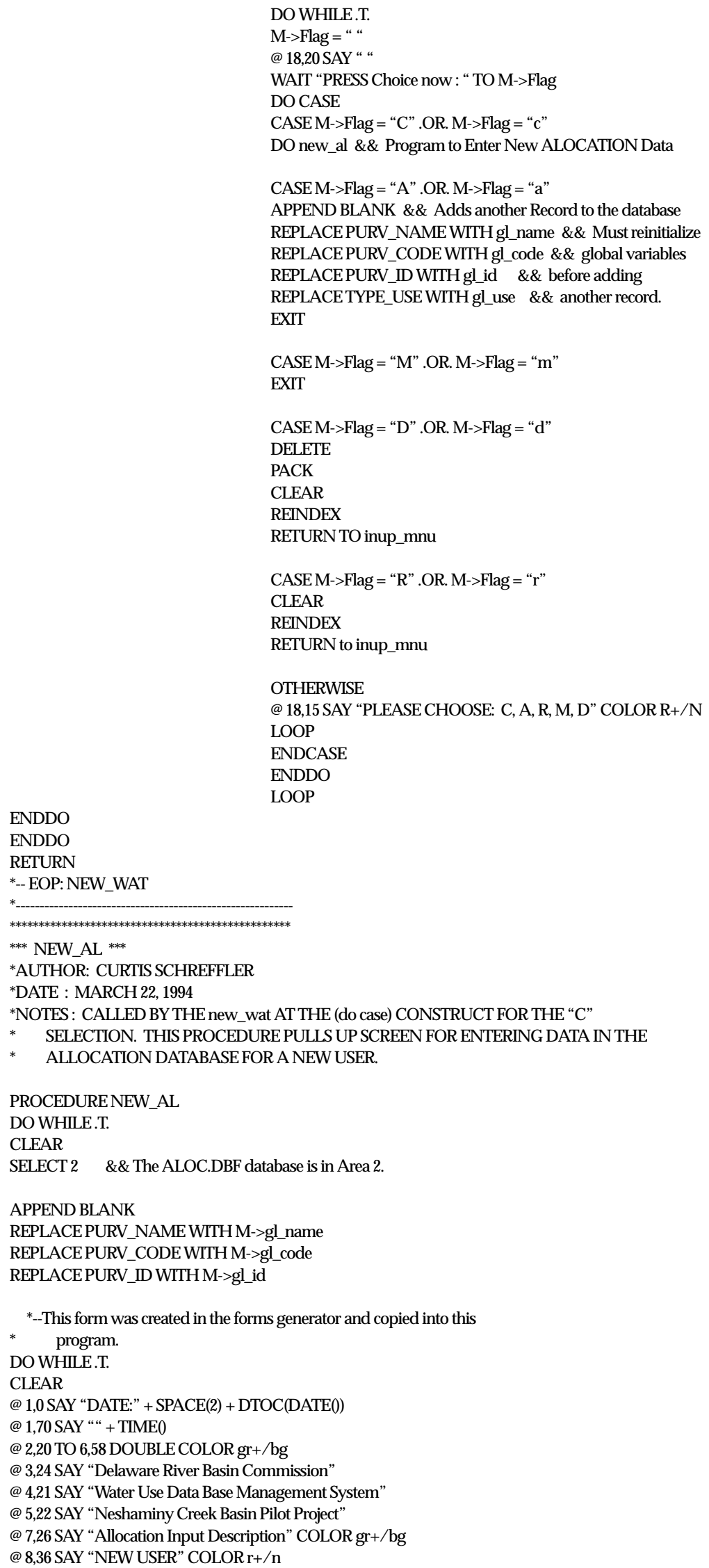

*-This form was created in the forms generator and copied into this program.

DOWHILE.T

CLEAR

@ 1,0SAY “DATE:" + SPACE(2) + DTOC(DATE())

@ 1,70SAY “" + TIME()

@ 2,20 TO 6,58 DOUBLECOLOR gr+/bg

@ 3,24 SAY "Delaware River Basin Commission"

@ 4,21 SAY "Water Use Data Base Management System"

@ 5,22 SAY "Neshaminy Creek Basin Pilot Project"

@ 7,26 SAY “Allocation Input Description" COLOR gr+/bg

@ 8,36SAY “NEW USER" COLOR $\mathrm{r}+/ \mathrm{n}$ 


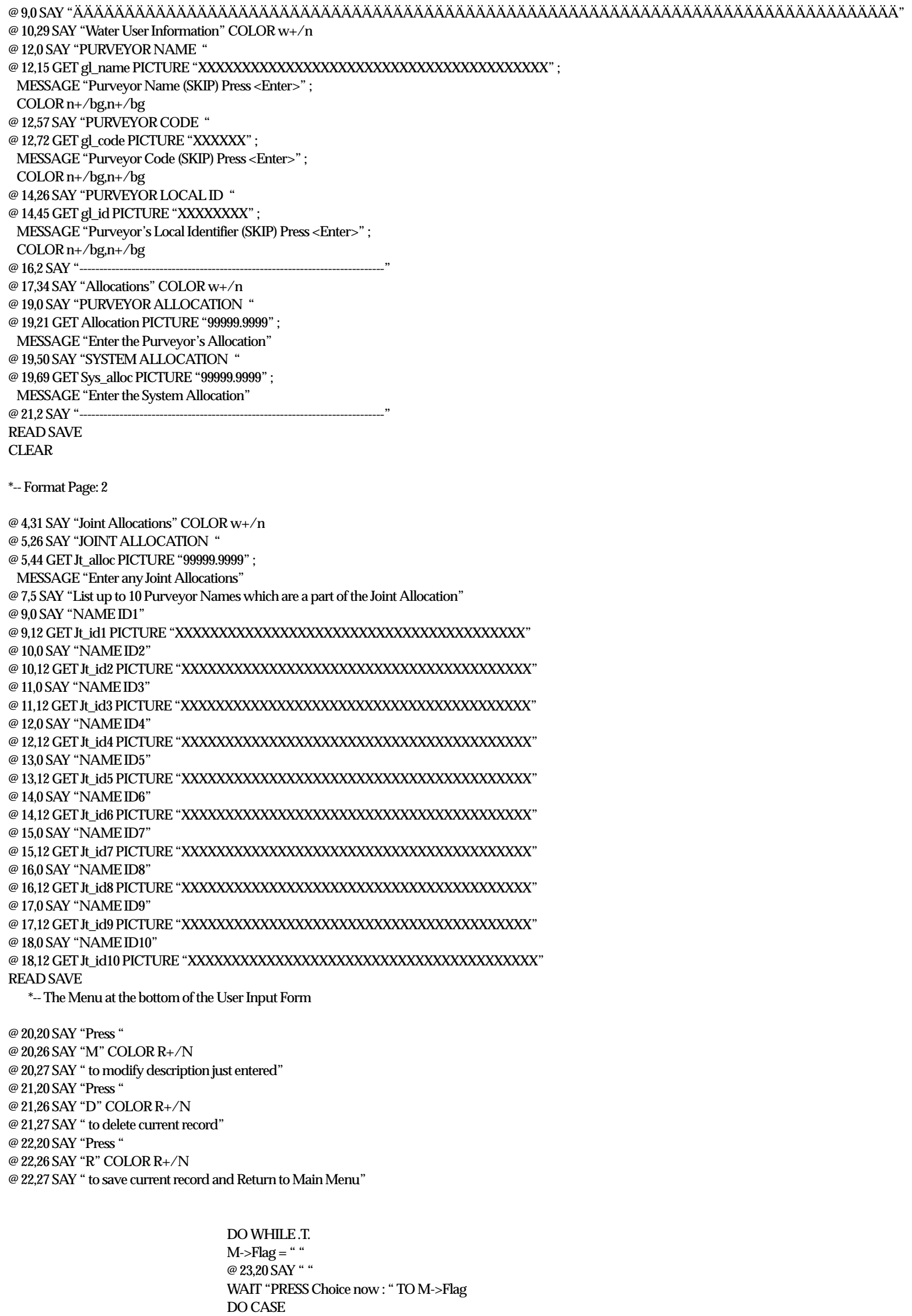




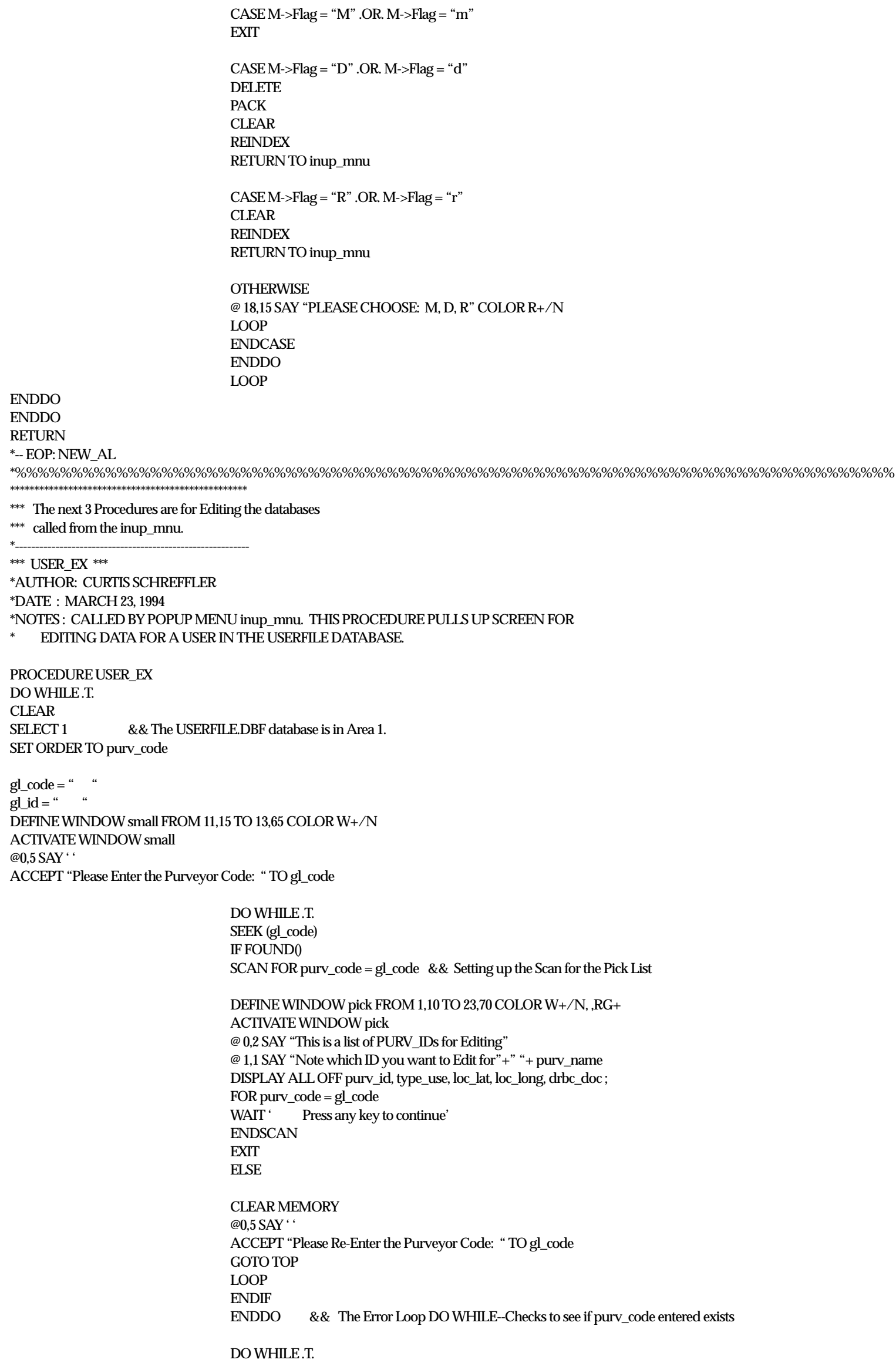




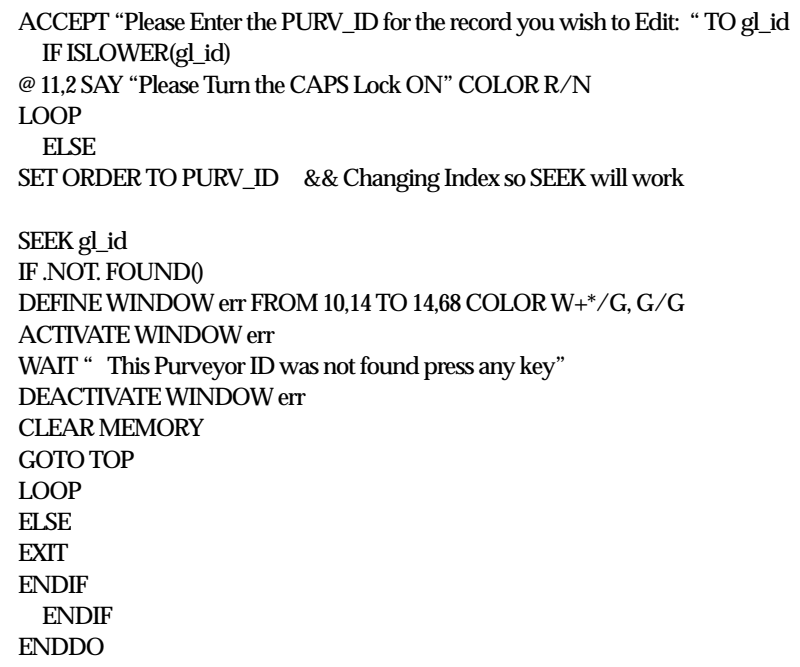

DEACTIVATE WINDOW pick

DEACTIVATE WINDOW small

\section{CLEAR}

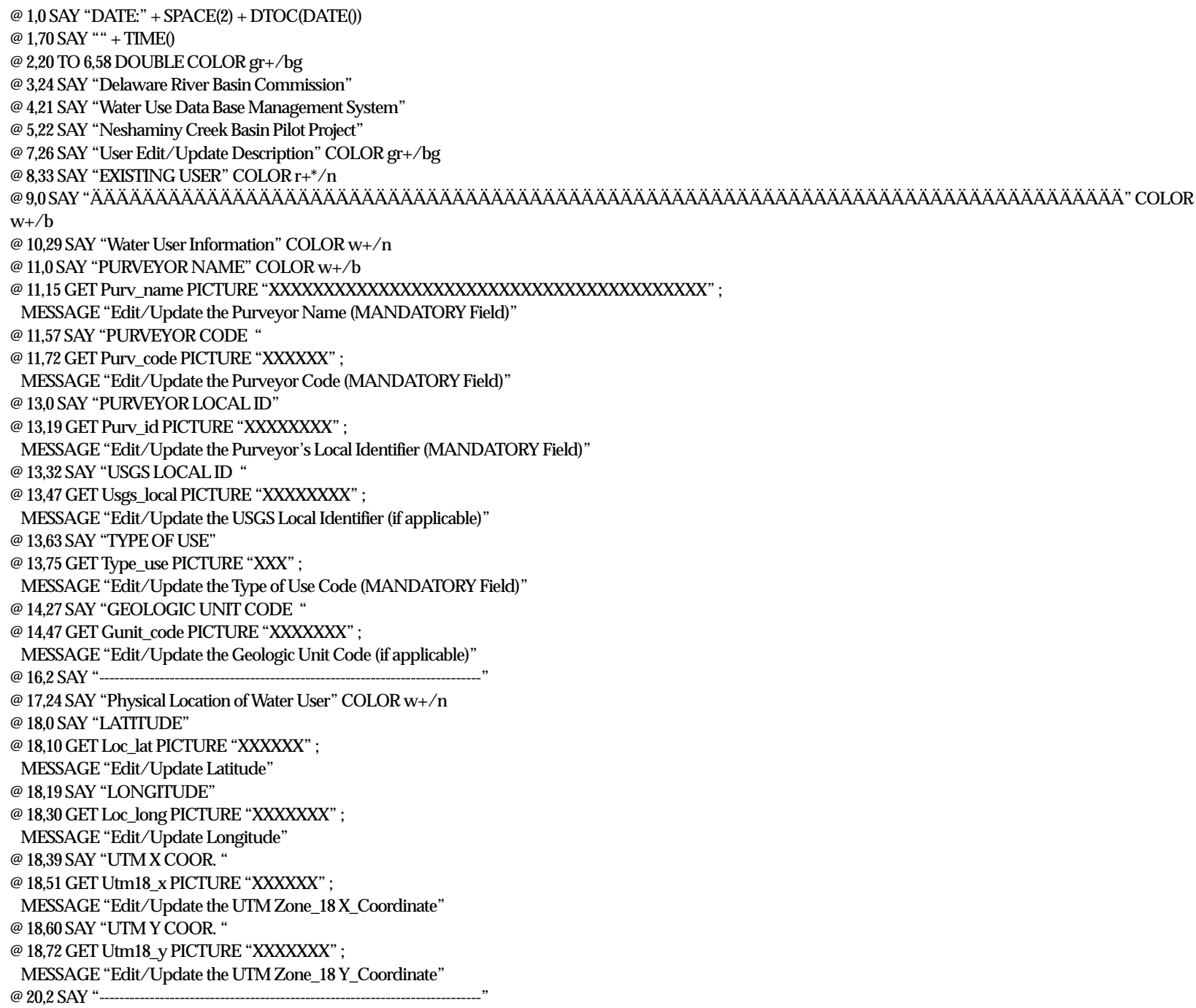




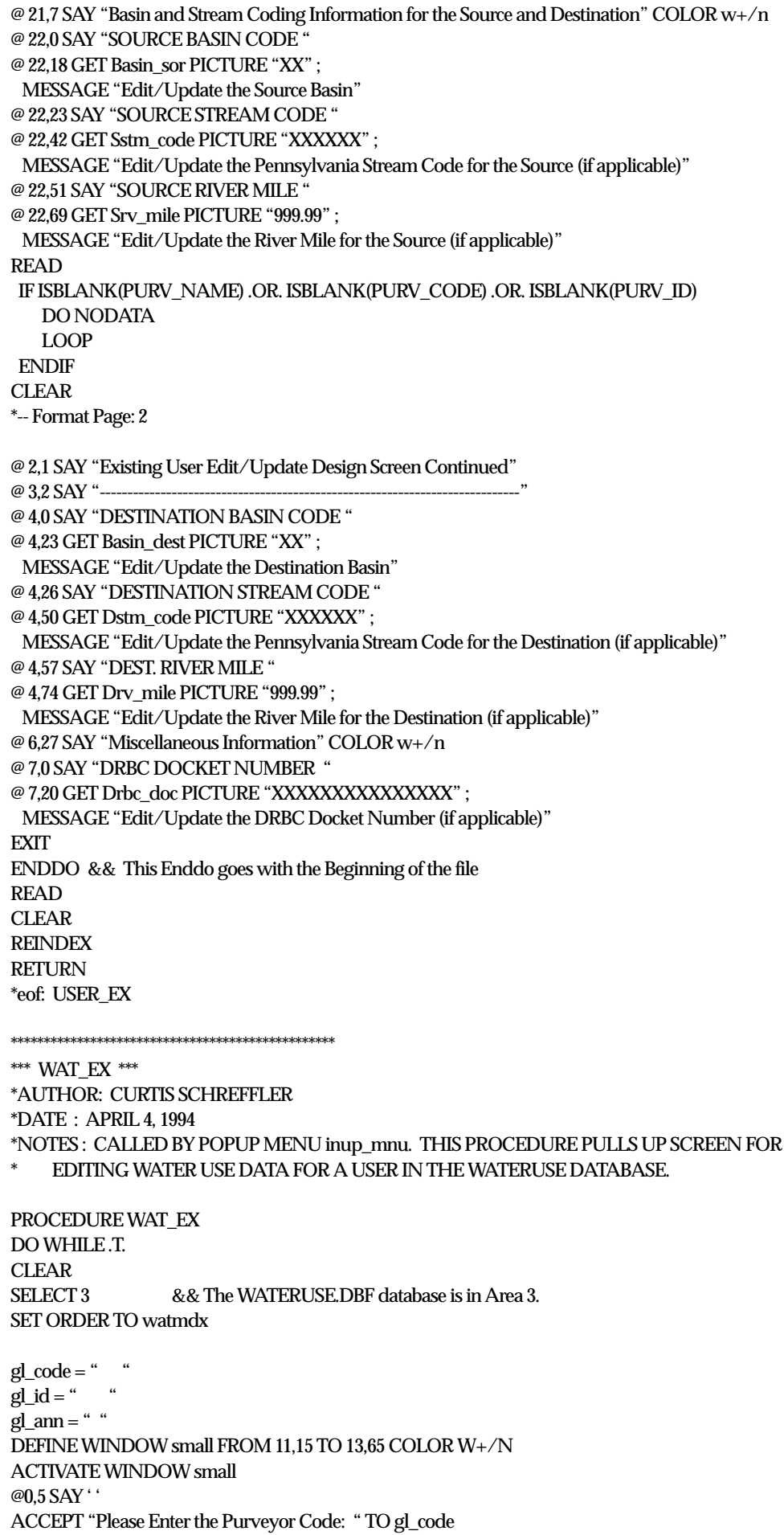

DOWHILE.T.

SEEK (gl_code)

IF FOUND()

SCANFOR purv_code $=$ gl_code $\& \&$ Setting up the Scan for the Pick List

DEFINE WINDOW pick FROM 1,0 TO 23,79 COLOR W+/N, RG+ ACTIVATE WINDOW pick @ 0,2SAY "This is a list of PURV IDs for Editing" 


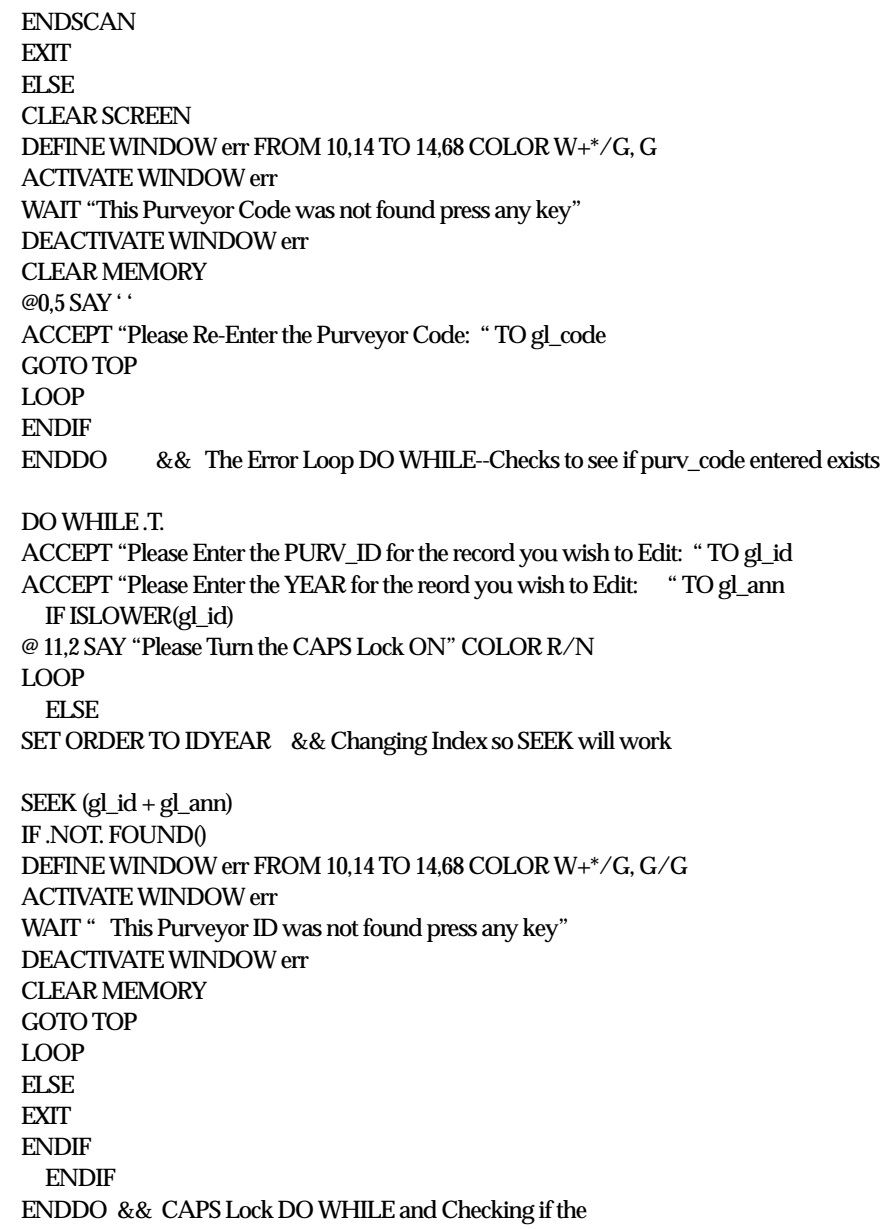


@ 18,22 SAY "Annual and Monthly Water Use Totals" COLOR w $+/ \mathrm{n}$

@ 20,27 SAY "ANNUAL TOTAL

@ 20,41 GET Annual_tot PICTURE “99999.9999”;

MESSAGE "Edit/Update the Total annual water use for the year"

@ 22,10SAY"

@ 23,0 SAY "JAN TOTAL "

@ 23,12 GET Jan_total PICTURE “99999.9999”

MESSAGE "Edit/Update the Total monthly water use for January"

@ 23,29 SAY "FEB TOTAL "

@ 23,41 GET Feb_total PICTURE “99999.9999”;

MESSAGE "Edit/Update the Total monthly water use for February"

@ 23,58 SAY "MAR TOTAL"

@ 23,70 GET Mar_total PICTURE “99999.9999” ;

MESSAGE "Edit/Update the Total monthly water use for March"

READ

IF ISBLANK(PURV NAME).OR. ISBLANK(PURV CODE).OR. ISBLANK(PURV ID)

DONODATA

LOOP

ENDIF

CLEAR

*-Format Page: 2

@ 2,1 SAY "Edited Water Use Totals Design Screen Continued"

(a) 3,2 SAY"

@ 5,0SAY "APR TOTAL"

@ 5,12 GET Apr_total PICTURE “99999.9999”;

MESSAGE "Edit/Update the Total monthly water use for April"

@ 5,29SAY "MAY TOTAL"

@ 5,41 GET May_total PICTURE “99999.9999” ;

MESSAGE "Edit/Update the Total monthly water use for May"

@ 5,58SAY “JUNTOTAL"

@ 5,70 GET Jun_total PICTURE “99999.9999”;

MESSAGE "Edit/Update the Total monthly water use for June"

@ 7,0 SAY "JUL TOTAL"

@ 7,12 GET Jul_total PICTURE “99999.9999” ;

MESSAGE "Edit/Update the Total monthly water use for July"

@ 7,29SAY "AUG TOTAL"

@ 7,41 GET Aug_total PICTURE “99999.9999”

MESSAGE "Edit/Update the Total monthly water use for August"

@ 7,58SAY "SEP TOTAL"

@ 7,70 GET Sep_total PICTURE “99999.9999” .

MESSAGE "Edit/Update the Total monthly water use for September"

@ 9,0SAY “OCT TOTAL"

@ 9,12 GET Oct_total PICTURE “99999.9999” ;

MESSAGE "Edit/Update the Total monthly water use for October"

@ 9,29SAY "NOV TOTAL"

@ 9,41 GET Nov_total PICTURE “99999.9999”;

MESSAGE "Edit/Update the Total monthly water use for November"

@ 9,58 SAY "DEC TOTAL"

@ 9,70 GET Dec total PICTURE “99999.9999”

MESSAGE "Edit/Update the Total monthly water use for December"

(1) 10,10SAY $\mathrm{SA}^{\prime * * * * * * * * * * * * * * * * * * * * * * * * * * * * * * * * * * * * * * * * * * * * * * * * * * * * * * * * * * * * * 1}$

EXIT

ENDDO

READ

CLEAR

REINDEX

RETURN

*** eof: WAT_EX

$* * *$ AL EX ***

*AUTHOR: CURTISSCHREFFLER

*DATE : APRIL 4, 1994

*NOTES: CALLED BY POPUP MENU inup_mnu. THIS PROCEDURE PULLS UP SCREEN FOR

* EDITING ALLOCATION DATA FOR A USER IN THE ALOC DATABASE

PROCEDURE AL_EX

DOWHILE.T.

CLEAR

SELECT 2 \&\& The ALOC.DBF database is in Area 2

SET ORDER TO purv_code

gl_code =" “

48 Water-Use Analysis Program for the Neshaminy Creek Basin, Bucks and Montgomery Counties, Pennsylvania 
gl_id $="$ "

DEFINE WINDOW small FROM 11,15 TO 13,65 COLOR W+/N

ACTIVATE WINDOW small

@0,5SAY" “

ACCEPT “Please Enter the Purveyor Code: “TOgl_code

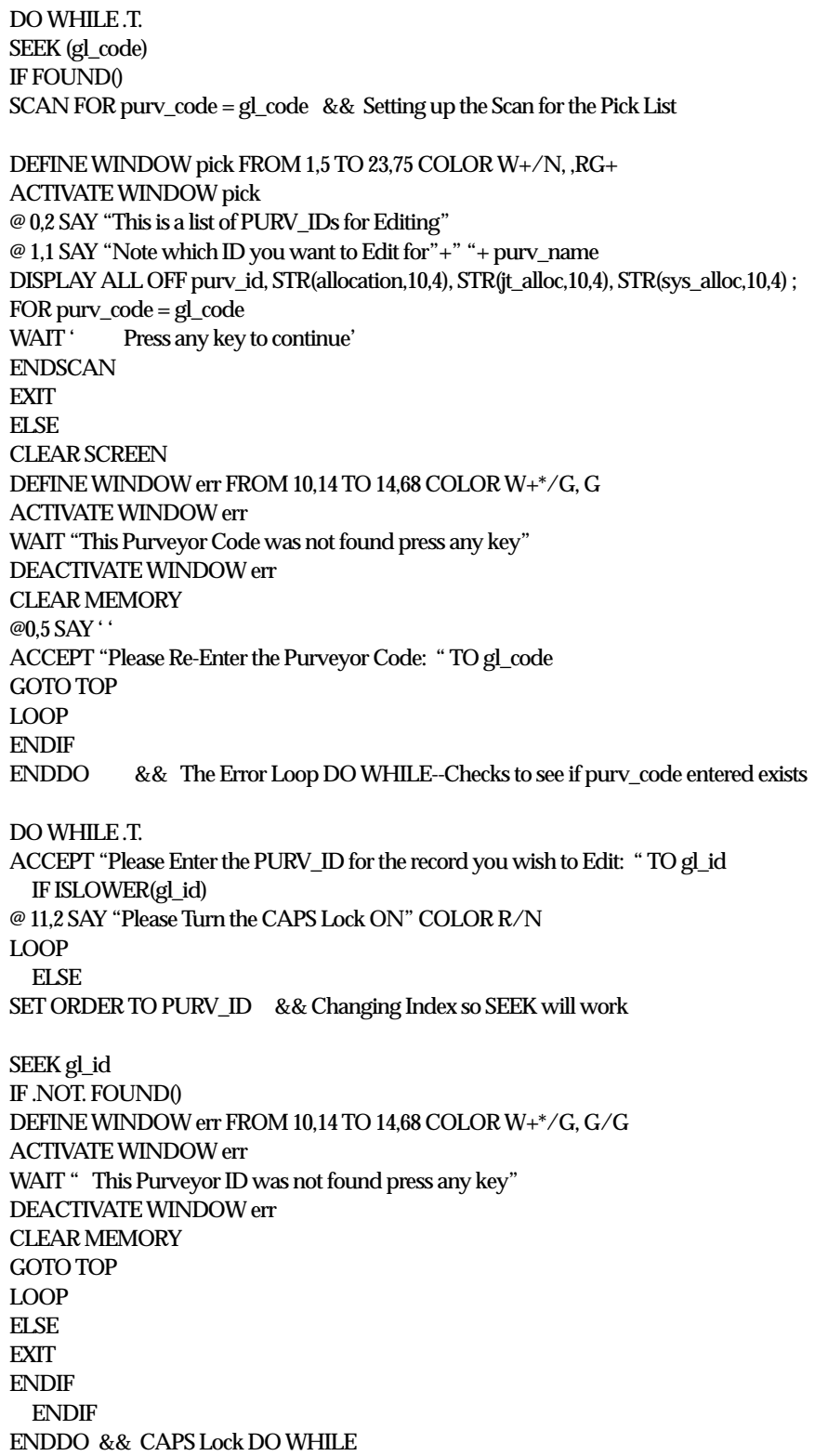




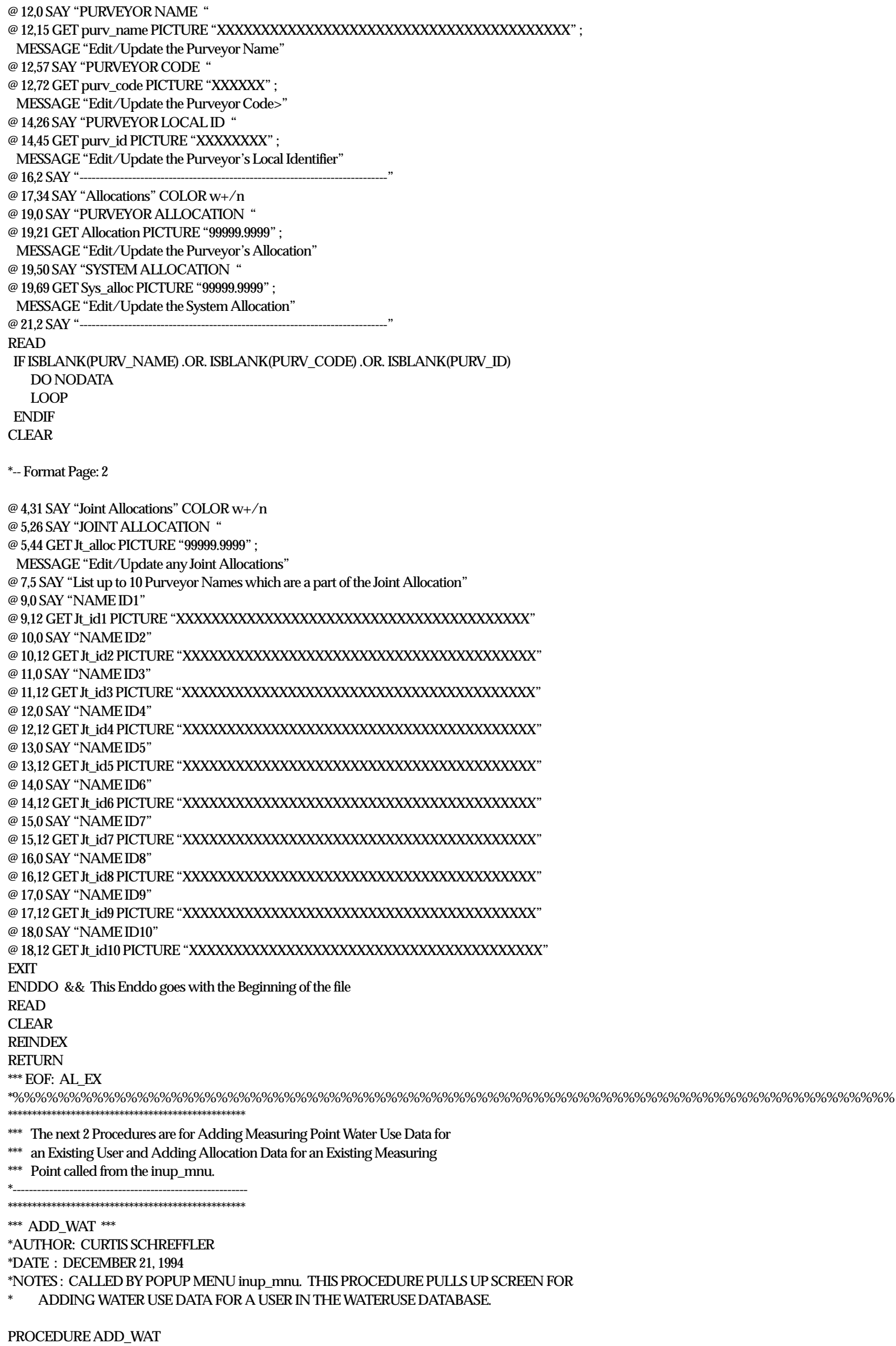


DOWHILE.T.

CLEAR

SELECT 3 \&\& The WATERUSE.DBF database is in Area 3.

SET ORDER TO watmdx

gl_code $=“ "$ “

gl_id $=$ “"

gl_name $="$ “

gl_use $="$ "

DEFINE WINDOW small FROM 11,15 TO 13,65 COLOR W+/N

ACTIVATE WINDOW small

$@ 0,5$ SAY" "

ACCEPT “Please Enter the Purveyor Code: “TOgl_code

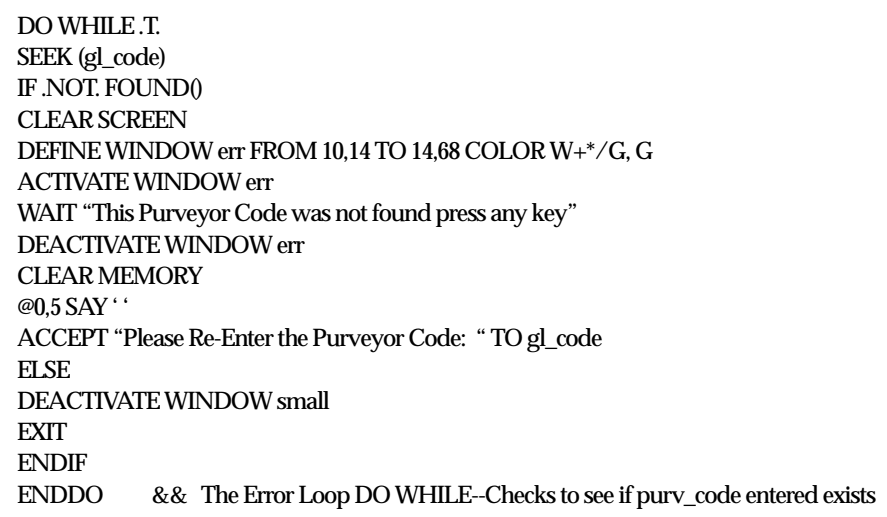

CLEAR

APPEND BLANK

REPLACE PURV_CODE WITH M->gl_code

DOWHILE.T.

CLEAR

@ 1,0SAY “DATE:" + SPACE(2) + DTOC(DATE())

@ 1,70 SAY ${ }^{\prime \prime \prime}+\mathrm{TIME} 0$

@ 2,20 TO 6,58 DOUBLE COLOR gr+/bg

@ 3,24 SAY "Delaware River Basin Commission"

@ 4,21 SAY "Water Use Data Base Management System"

@ 5,22SAY "Neshaminy Creek Basin Pilot Project"

@ 7,24SAY "Water Use Totals Adding New Data" COLOR gr+/bg

@ 8,34 SAY “EXISTING USER" COLOR r+*/n

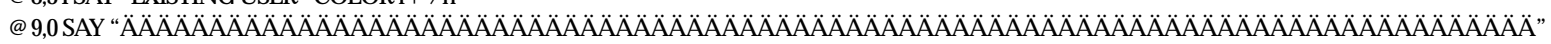

@ 10,29 SAY "Water User Information" COLOR w+/n

@ 12,0 SAY “PURVEYOR NAME" COLOR w+/b

@ 12,13SAY" “

@ 12,15GET purv_name PICTURE " $X X X X X X X X X X X X X X X X X X X X X X X X X X X X X X X X X X X X X X X X X X$ ";

MESSAGE "Enter the Purveyor Name (MANDATORY)"

@ 12,57 SAY “PURVEYOR CODE “

@ 12,72 GET gl_codePICTURE "XXXXXX" ;

MESSAGE “Purveyor Code (SKIP)" COLOR n+/bg, n+/bg

@ 14,0 SAY “PURVEYOR LOCAL ID “

@ 14,19 GET purv_id PICTURE " $X X X X X X X X$ " .

MESSAGE "Enter the Purveyor's Local Identifier (MANDATORY)"

@ 14,39SAY "TYPE OFUSE "

@ 14,52 GET type_use PICTURE "XXX";

MESSAGE "Enter the Type of Use Code (MANDATORY)"

@ 14,70 SAY "YEAR" COLOR w+/b

@ 14,76 GET Ann_year PICTURE "XX";

MESSAGE "Enter the Year for which the following data apply (MANDATORY)"

@ 16,2SAY"

@ 18,22 SAY "Annual and Monthly Water Use Totals" COLOR w+/n

@ 20,27 SAY “ANNUAL TOTAL "

@ 20,41 GET Annual_tot PICTURE “99999.9999";

MESSAGE "Enter the Total annual water use for the year"

@ 22,10SAY

@ 23,0SAY “JAN TOTAL “

@ 23,12 GET Jan_total PICTURE "99999.9999"; 
MESSAGE "Enter the Total monthly water use for January"

@ 23,29SAY "FEB TOTAL "

@ 23,41 GET Feb_total PICTURE “99999.9999” ;

MESSAGE "Enter the Total monthly water use for February"

@ 23,58 SAY "MAR TOTAL "

@ 23,70 GET Mar_total PICTURE “99999.9999” ;

MESSAGE "Enter the Total monthly water use for March"

READSAVE

IF ISBLANK(PURV_NAME).OR. ISBLANK(PURV_CODE).OR. ISBLANK(PURV_ID)

DONODATA

LOOP

ENDIF

CLEAR

*-Format Page: 2

@ 2,1 SAY "Adding New Water Use Totals Input Design Screen Continued"

@3,2 SAY"

@ 5,0SAY "APR TOTAL"

@ 5,12 GET Apr_total PICTURE “99999.9999”;

MESSAGE "Enter the Total monthly water use for April"

@ 5,29SAY "MAY TOTAL"

@ 5,41 GET May_total PICTURE “99999.9999”;

MESSAGE “Enter the Total monthly water use for May"

@ 5,58SAY "JUN TOTAL"

@ 5,70 GET Jun_total PICTURE “99999.9999”.

MESSAGE "Enter the Total monthly water use for June"

@ 7,0SAY "JUL TOTAL"

@ 7,12 GET Jul_total PICTURE “99999.9999” ;

MESSAGE "Enter the Total monthly water use for July"

@ 7,29SAY "AUG TOTAL"

@ 7,41 GET Aug_total PICTURE “99999.9999”;

MESSAGE "Enter the Total monthly water use for August"

@ 7,58SAY "SEP TOTAL"

@ 7,70 GET Sep_total PICTURE “99999.9999” .

MESSAGE "Enter the Total monthly water use for September"

@ 9,0SAY "OCT TOTAL"

@ 9,12 GET Oct_total PICTURE “99999.9999” ;

MESSAGE "Enter the Total monthly water use for October"

@ 9,29SAY "NOV TOTAL"

@ 9,41 GET Nov_total PICTURE “99999.9999”;

MESSAGE "Enter the Total monthly water use for November"

@ 9,58 SAY "DEC TOTAL"

@ 9,70 GET Dec_total PICTURE “99999.9999”

MESSAGE "Enter the Total monthly water use for December"

@ 10,10SAY

READSAVE

*- The Menu at the bottom of the User Input Form (1) 12,20 SAY "Press"

@ 12,26SAY "C" COLOR R+/N

@ 12,27 SAY " to continue to input Allocation data"

(a) 13,20 SAY "Press"

@ 13,26SAY "A" COLOR R+/N

@ 13,27 SAY " to Add another Year of data"

@ 14,20 SAY "Press"

@ 14,26SAY "M" COLOR R+/N

@ 14,27 SAY " to modify description just entered"

@ 15,20 SAY "Press "

@ 15,26SAY “D” COLOR R+/N

@ 15,27 SAY " to delete current record"

@ 16,20SAY "Press"

@ 16,26SAY "R" COLOR R+/N

@ 16,27 SAY " to save current record and Return to Main Menu"

DOWHILE.T.

M->Flag =" "

@ 18,20SAY" “

WAIT "PRESS Choice now : " TO M->Flag

DOCASE

CASE M- $>$ Flag $=$ "C" .OR. M->Flag $="{ }^{c} "$

STOREPURV_IDTOgl_id

STORE PURV_NAMETOgl_name 
DOnew_al \&\& Program to Enter New ALOCATION Data

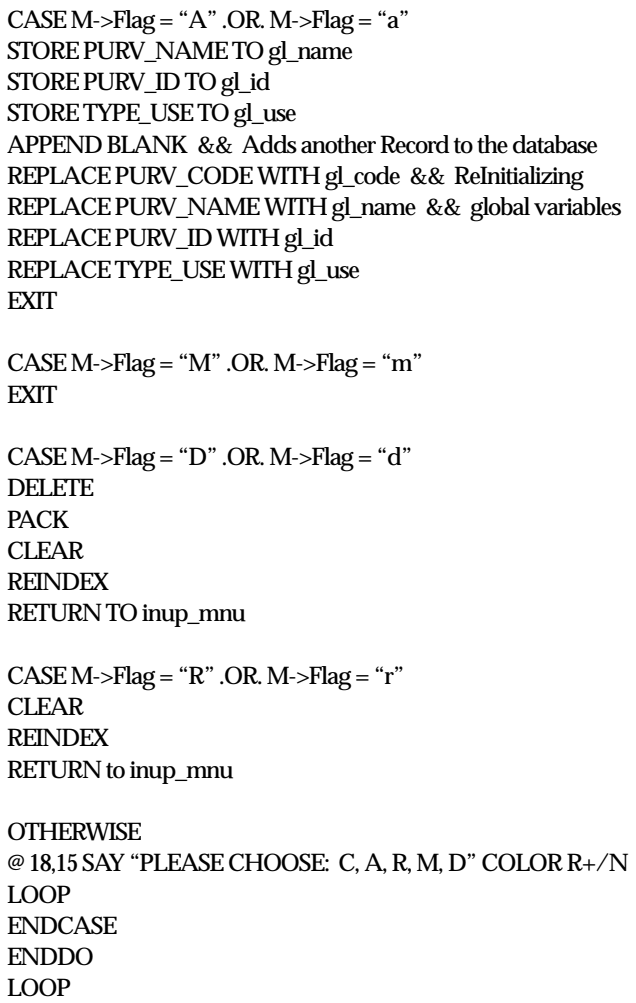

PROCEDURE ADD_ALOC

DOWHILE.T.

CLEAR

SELECT 3 \&\& The WATERUSE.DBF database is in Area 3

SET ORDER TO purv_code

gl code $="$ "

gl_id =" "

gl_name $=$ " "

DEFINE WINDOW small FROM 11,15 TO 13,65 COLOR W+/N

ACTIVATE WINDOW small

@0,5 SAY " ‘

ACCEPT "Please Enter the Purveyor Code: “ TOgl_code

DOWHILE.T.

SEEK (gl_code)

IFFOUND()

SCAN FOR purv_code $=$ gl_code \&\& Setting up the Scan for the Pick List

DEFINE WINDOW pick FROM 1,5 TO 23,75 COLOR W+/N, RG+ ACTIVATE WINDOW pick @ 0,2SAY "This is a list of PURV_IDs for Adding DATA"

@ 1,1 SAY "Note which ID you want to ADD Data for" +" "+ purv_name DISPLAY ALL OFF purv_id, type_use, ann_year,STR(annual_tot,10,4) ;

FOR purv_code $=$ gl_code

WAIT' Press any key to continue 


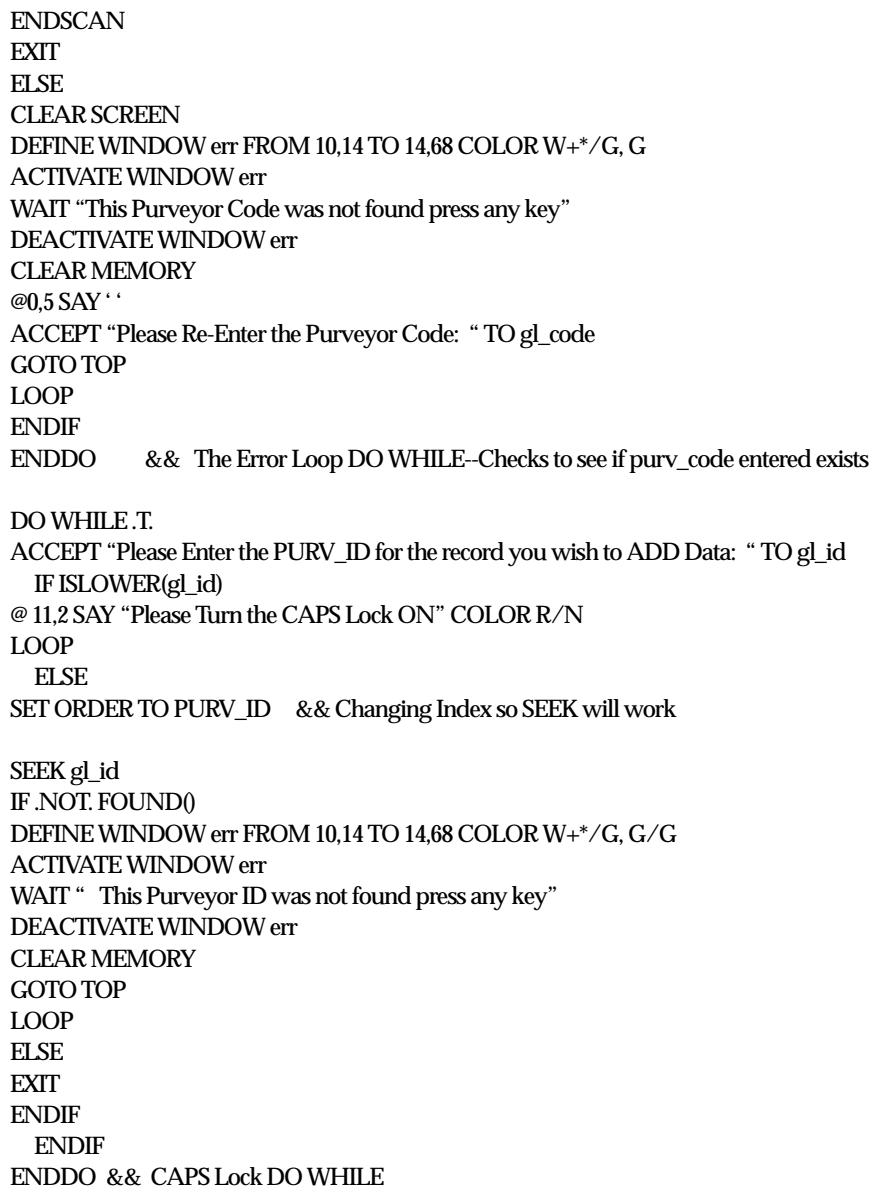

DEACTIVATE WINDOW pick DEACTIVATE WINDOW small STORE PURV_NAME TOgl_name STORE PURV_CODE TO gl_code STORE PURV_IDTOgl_id

SELECT 2

APPEND BLANK

REPLACE PURV_NAME WITH gl_name REPLACE PURV_CODEWITH gl_code REPLACE PURV_IDWITH gl_id

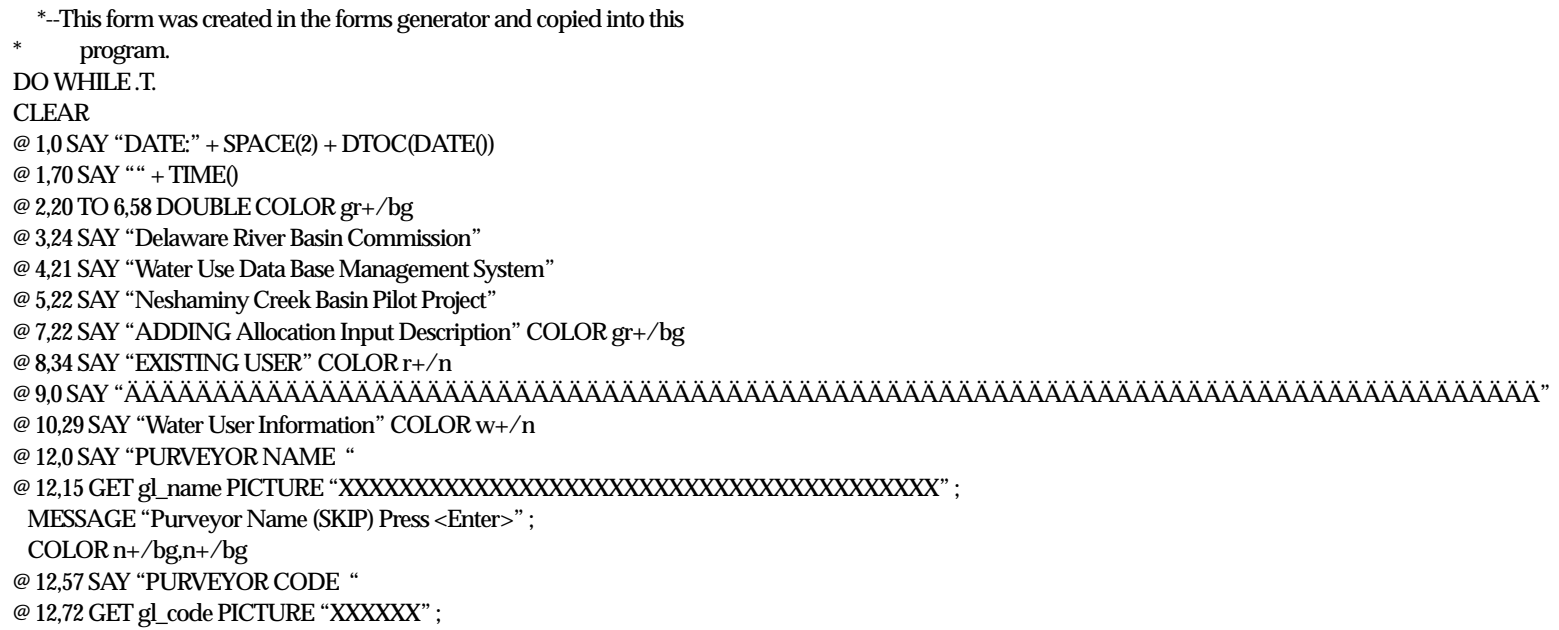


MESSAGE “Purveyor Code (SKIP) Press <Enter>”;

COLOR $n+/$ bg, $n+/$ bg

@ 14,26 SAY "PURVEYOR LOCAL ID "

@ 14,45 GET gl_id PICTURE "XXXXXXXX" ;

MESSAGE "Purveyor's Local Identifier (SKIP) Press <Enter>"

COLOR $n+/$ bg, $n+/$ bg

@ 16,2SAY"

@ 17,34 SAY "Allocations" COLOR w+/n

@ 19,0 SAY “PURVEYOR ALLOCATION “

@ 19,21 GET Allocation PICTURE “99999.9999”;

MESSAGE "Enter the Purveyor's Allocation"

@ 19,50 SAY “SYSTEM ALLOCATION “

@ 19,69 GET Sys_alloc PICTURE “99999.9999”;

MESSAGE "Enter the System Allocation"

@ 21,2SAY"

READSAVE

CLEAR

*-Format Page: 2

@ 4,31 SAY "Joint Allocations" COLOR w+/n

@ 5,26SAY "JOINT ALLOCATION “

@ 5,44 GET Jt_alloc PICTURE “99999.9999”;

MESSAGE "Enter any Joint Allocations"

@ 7,5SAY "List up to 10 Purveyor Names which are a part of the Joint Allocation"

@ 9,0 SAY "NAME ID1"

@ 9,12 GET Jt_id1 PICTURE "XXXXXXXXXXXXXXXXXXXXXXXXXXXXXXXXXXXXXXXX”

@ 10,0SAY "NAME ID2"

@ 10,12 GET Jt_id2 PICTURE “ $X X X X X X X X X X X X X X X X X X X X X X X X X X X X X X X X X X X X X X X X$ ” @ 11,0SAY "NAME ID3"

@ 11,12 GET Jt_id3 PICTURE “ $X X X X X X X X X X X X X X X X X X X X X X X X X X X X X X X X X X X X X X X X$ ” @ 12,0 SAY "NAME ID4"

@ 12,12 GET Jt_id4 PICTURE “XXXXXXXXXXXXXXXXXXXXXXXXXXXXXXXXXXXXXXXX" @ 13,0 SAY "NAMEID5"

@ 13,12 GET Jt_id5 PICTURE " $X X X X X X X X X X X X X X X X X X X X X X X X X X X X X X X X X X X X X X X X$ ” @ 14,0SAY "NAME ID6"

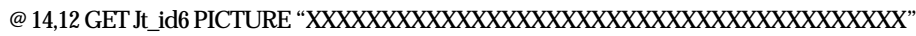
@ 15,0 SAY "NAME ID7"

@ 15,12 GET Jt id7 PICTURE " $X X X X X X X X X X X X X X X X X X X X X X X X X X X X X X X X X X X X X X X X$ "

@ 16,0SAY “NAME ID8"

@ 16,12 GET Jt id8 PICTURE “ $X X X X X X X X X X X X X X X X X X X X X X X X X X X X X X X X X X X X X X X X$ ”

@ 17,0SAY “NAME ID9"

@ 17,12 GET Jt_id9 PICTURE " $X X X X X X X X X X X X X X X X X X X X X X X X X X X X X X X X X X X X X X X X$ "

@ 18,0 SAY “NAME ID10"

@ 18,12 GET Jt_id10 PICTURE " $X X X X X X X X X X X X X X X X X X X X X X X X X X X X X X X X X X X X X X X X$ "

READSAVE

*- The Menu at the bottom of the User Input Form

@ 20,20 SAY "Press "

@ 20,26 SAY "M" COLOR R+/N

@ 20,27 SAY " to modify description just entered"

( 21,20 SAY "Press"

@ 21,26SAY "D" COLOR R+/N

@ 21,27 SAY " to delete current record"

( 22,20 SAY "Press"

@ 22,26SAY "R" COLOR R+/N

@ 22,27 SAY " to save current record and Return to Main Menu"

DOWHILE.T.

$\mathrm{M}->$ Flag $="$ "

@ 23,20SAY " “

WAIT "PRESS Choice now : “ TO M->Flag

DOCASE

CASE M->Flag = "M".OR. M->Flag = "m"

EXIT

CASE M->Flag $=$ "D" .OR. M->Flag $=$ "d"

DELETE

PACK

CLEAR

REINDEX

RETURNTO inup_mnu 


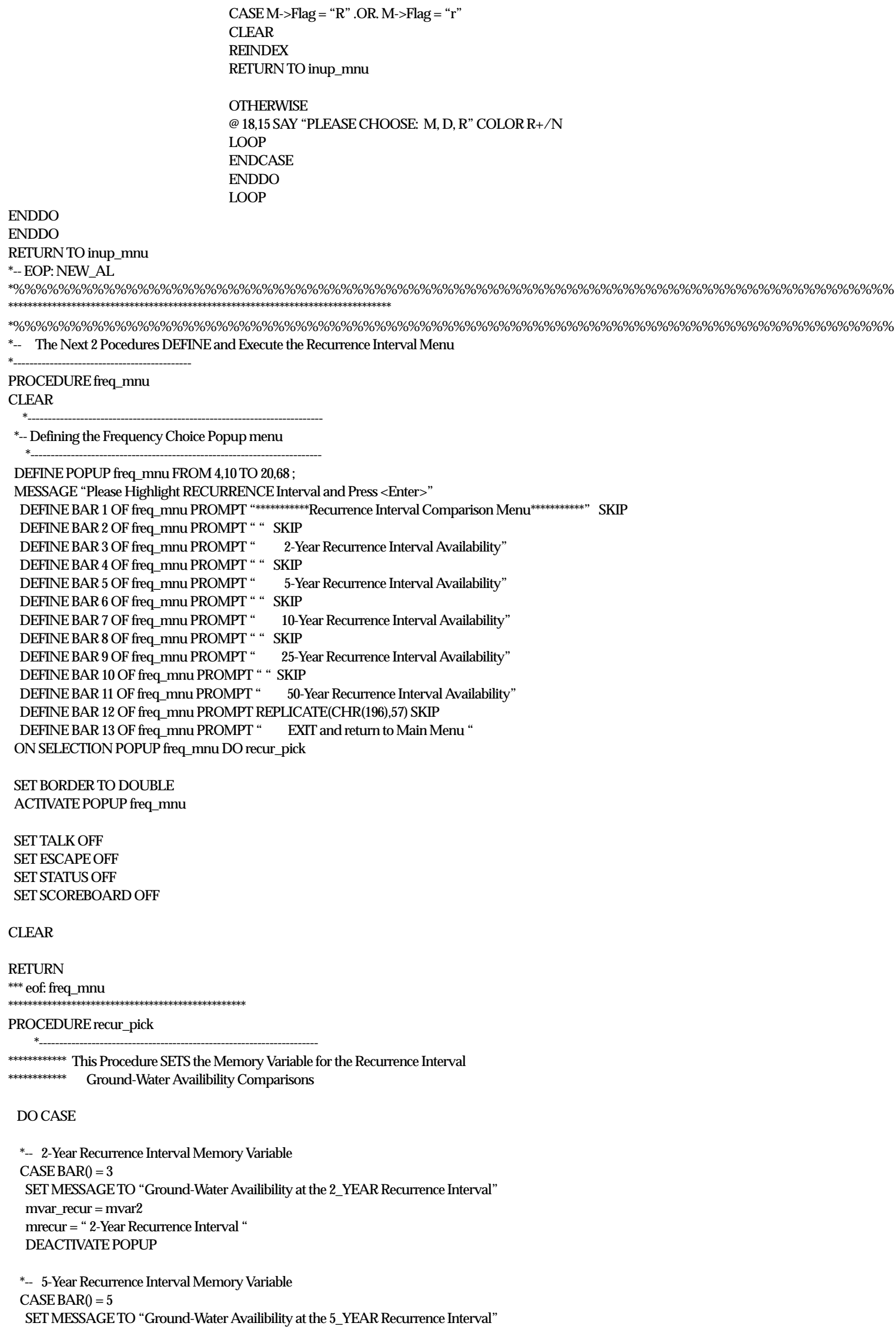




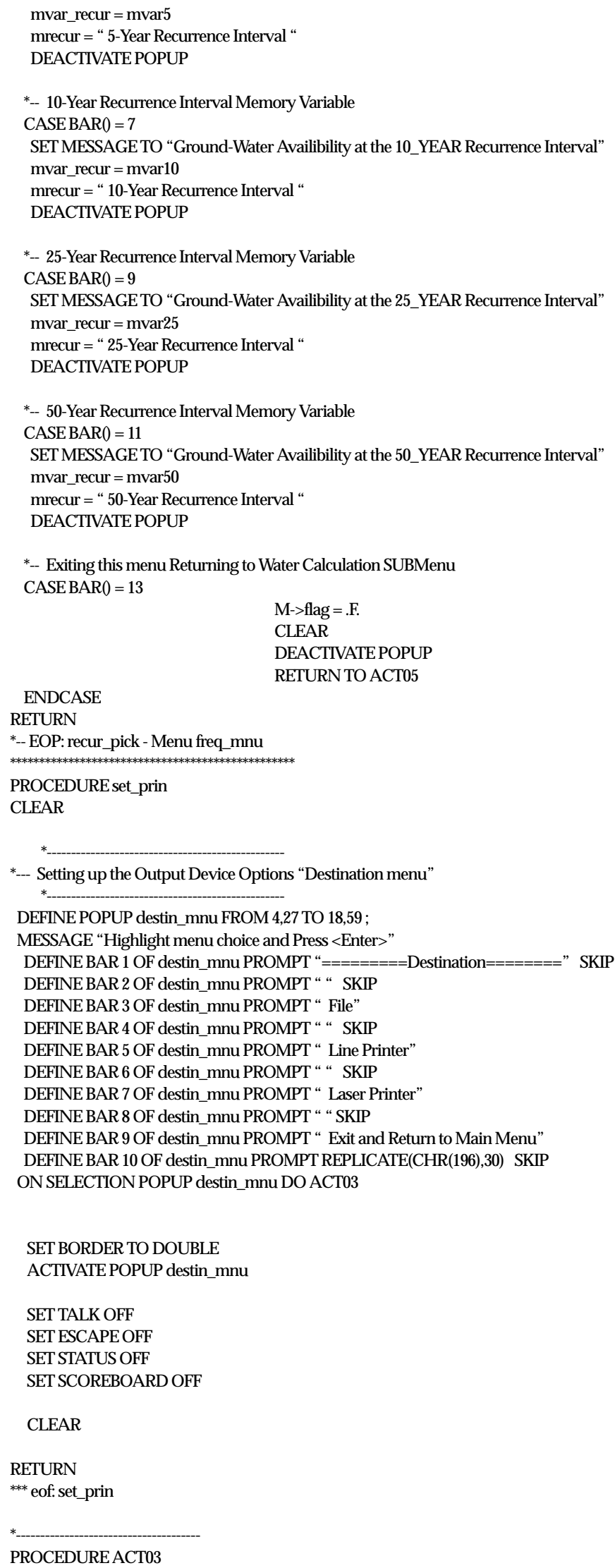




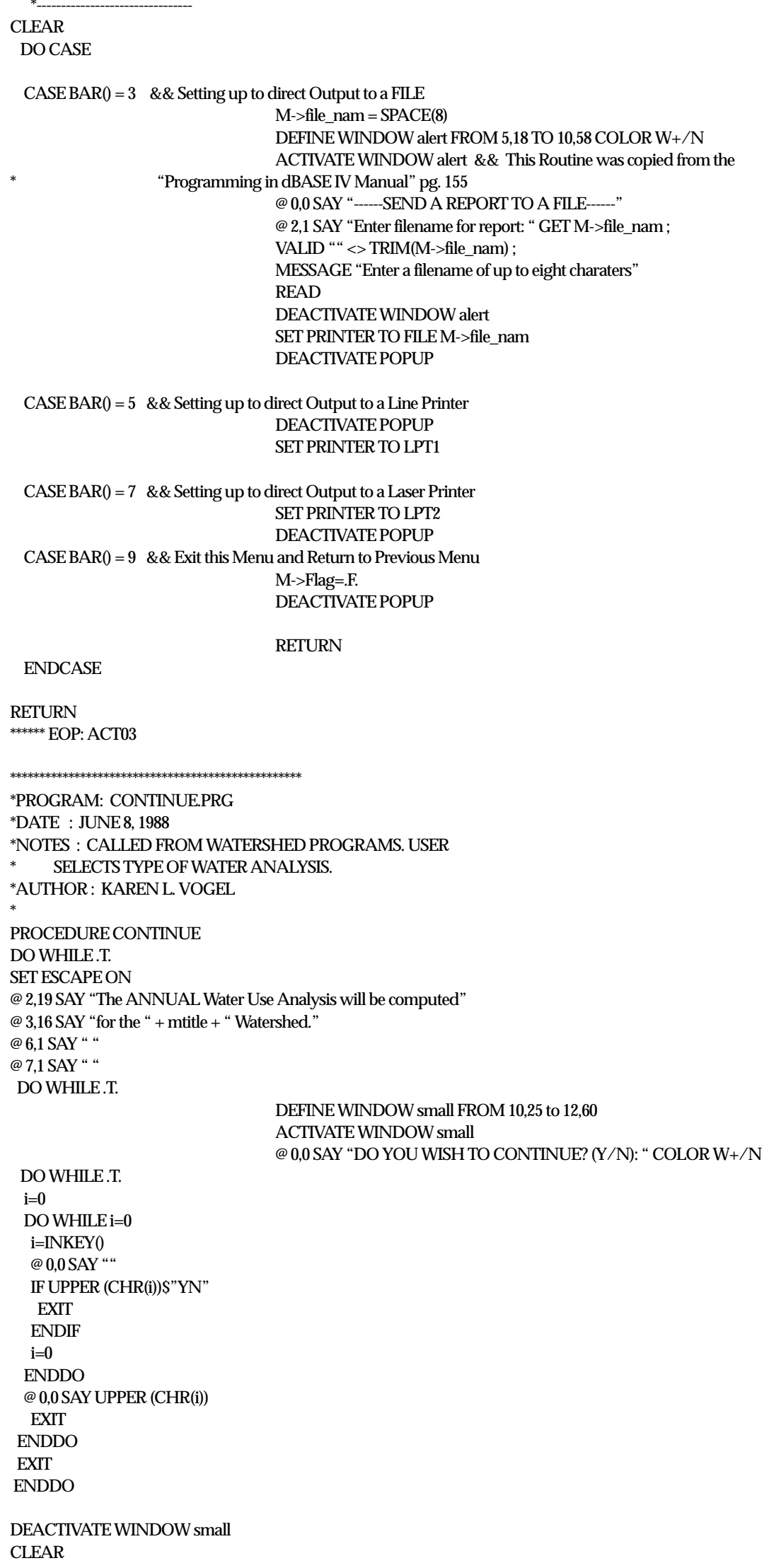




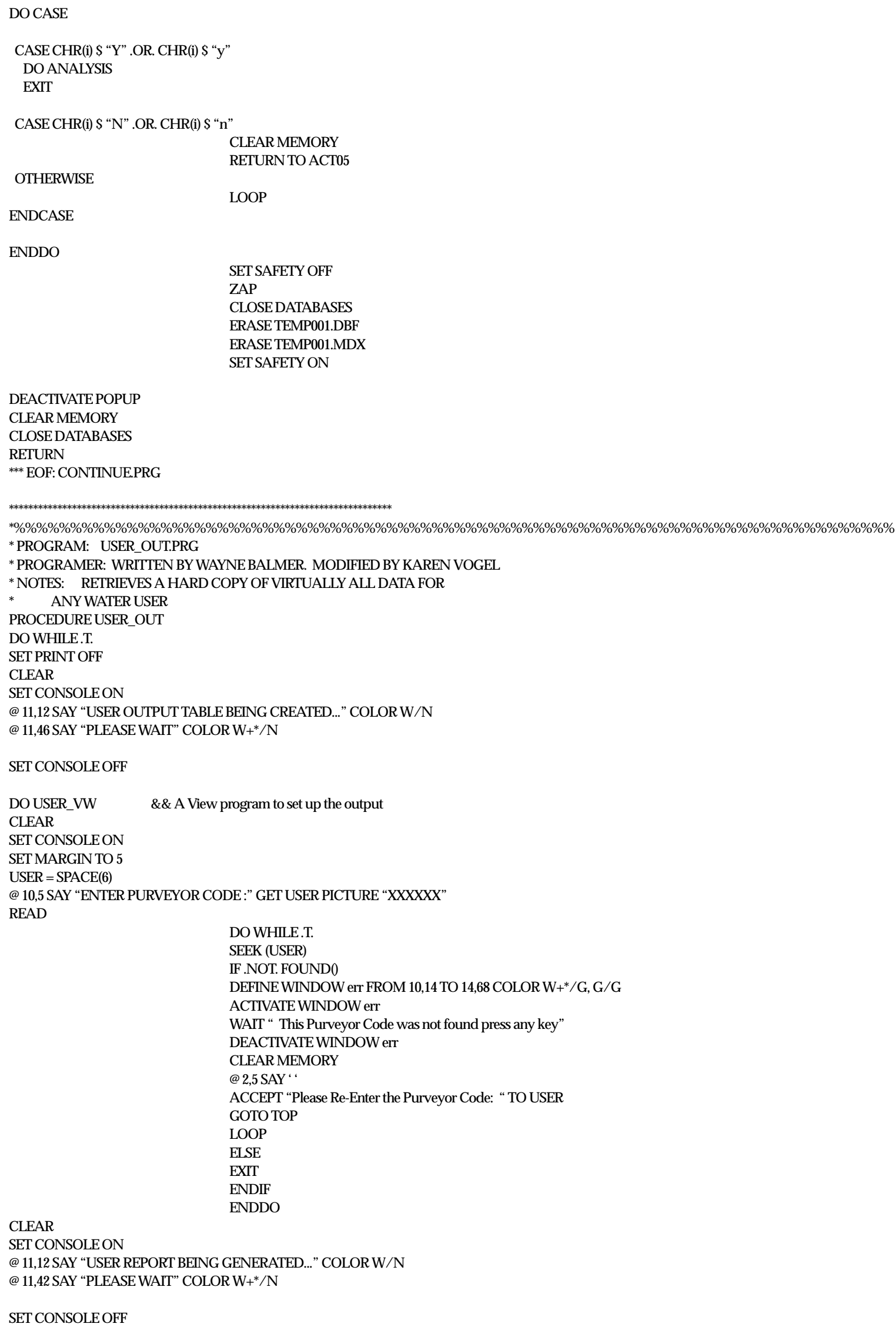

SET CONSOLEOFF 
REPORT FORM REPORTS \RPT_USER NOEJECT FOR C->PURV_CODE=USER TOPRINTER

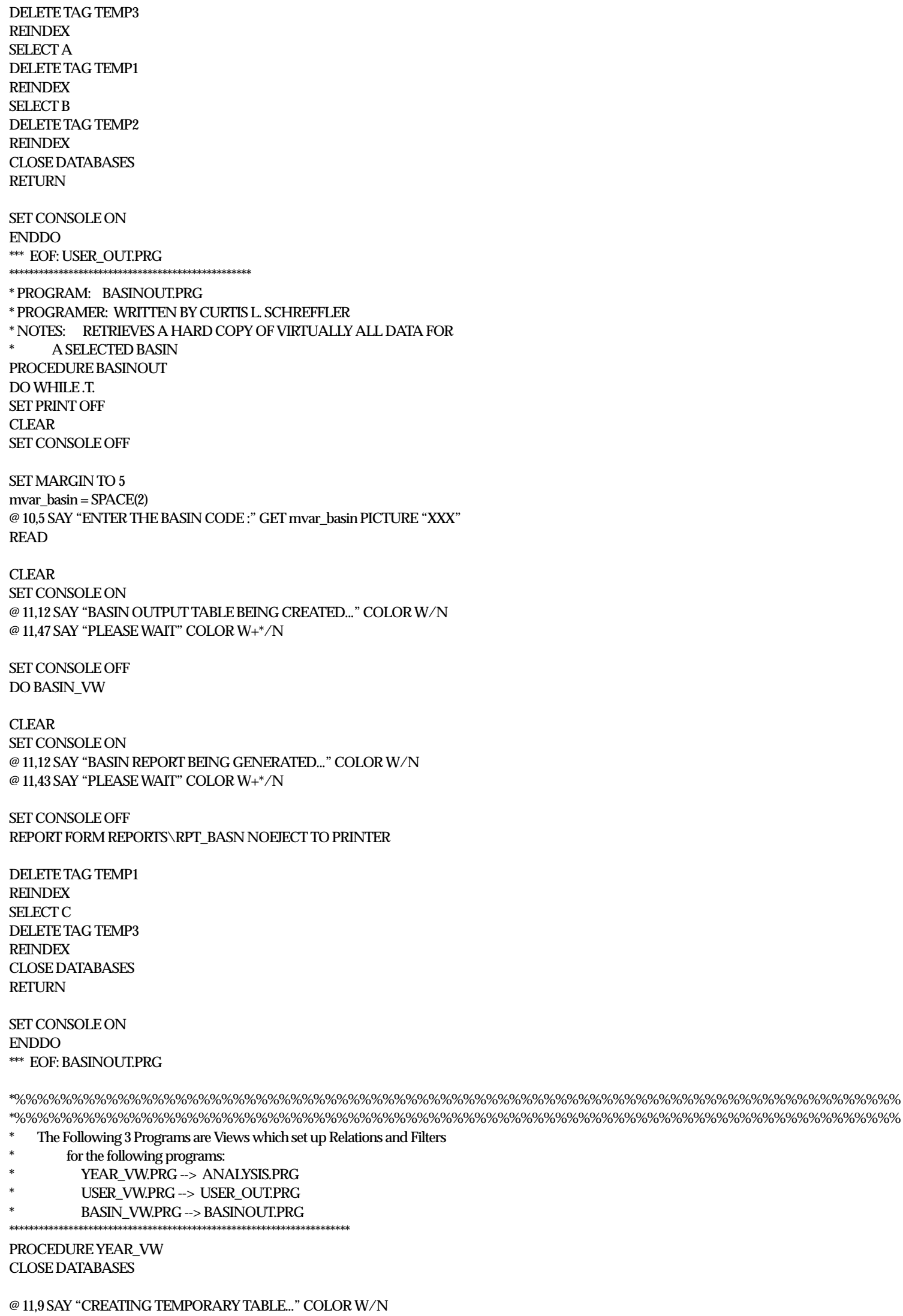


@ 11,36SAY “PLEASE WATT” COLOR W+*/N

USE WATERUSE

SORT TO TEMP001 ON PURV_CODE /A, PURV_ID /A, ANN_YEAR /D

SET EXACT ON

SELECT 3

USE TEMP001 EXCLUSIVE

INDEX ON PURV_ID TAG IDOF TEMP001.MDX FOR (ANN_YEAR <=STR(mvar_yr,2,0)) UNIQUE

USE USERFILE IN 1 ORDER PURV_ID

USE ALOC IN 2 ORDER PURV_ID

SET RELATION TOC->PURV_IDINTO A

SELECT 1

SET RELATION TO A->PURV_IDINTOB

SELECT 3

SET FILTER TOFOUND(1).AND. TYPE_USE=A->TYPE_USE .AND. PURV_ID=A->PURV_ID;

.AND. (A->BASIN_SOR=mvar_basin.OR. A->BASIN_DEST=mvar_basin)

SET SKIP TO A

GOTOP

SET FIELDS TO A->PURV_CODE, A->PURV_ID, A->PURV_NAME, A->BASIN_SOR, A->BASIN_DEST, ;

C->TYPE_USE /R, C->ANN_YEAR, C->ANNUAL_TOT, B->ALLOCATION,

B- $>$ TT_ALLOC, B->SYS_ALLOC

RETURN

*** EOF: YEAR_VW.PRG

$* * * * * * * * * * * * * * * * * * * * * * * * * * * * * * * * * * * * * * * * * * * * * * * * *$

PROCEDURE USER_VW

SET CONSOLEON

CLOSE DATABASES

SELECT A

USE USERFILE IN A

INDEXON PURV_CODE + PURV_IDTAG TEMP1

SELECT B

USE ALOC IN B

INDEX ON PURV CODE + PURV IDTAG TEMP2

SELECTC

USE WATERUSE IN C

INDEX ON PURV_CODE + PURV_IDTAG TEMP3

SELECT A

USE USERFILE IN A ORDER TEMP1

SET RELATION TOPURV_IDINTOC

SET SKIP TOC

SELECTC

USE WATERUSE IN C ORDER TEMP3

SET RELATION TO PURV_CODE + PURV_IDINTO B, PURV_CODE + PURV_IDINTO A

GOTOP

SET FIELDS TOC->PURV_CODE, C->PURV_ID, B->ALLOCATION, B->JT_ALLOC, B->SYS_ALLOC, ;

C->ANN_YEAR, C->ANNUAL_TOT, A->PURV_NAME, A->USGS_LOCAL, A- $>$ TYPE_USE,

A->LOC LAT, A->LOC LONG, A->UTM18 X, A->UTM18 Y, A->GUNIT CODE,

A->BASIN_SOR, A->SSTM_CODE, A->SRV_MILE, A->BASIN_DEST, A->DSTM_CODE, ;

A->DRV_MILE, A->DRBC_DOC

RETURN

*** EOF: USER_VW.PRG

PROCEDURE BASIN VW

CLOSE DATABASES

SELECT A

USE USERFILE

INDEX ON PURV CODE + PURV IDTAG TEMP1

SELECTC

USE WATERUSE

INDEXON PURV_CODE + PURV_IDTAG TEMP3

SET ORDER TO TEMP3

SELECT A

USE USERFILE IN A ORDER TEMP1

SET RELATION TO PURV_CODE + PURV_IDINTOC

SET SKIP TOC

SET FILTER TO (A->BASIN_SOR=mvar_basin .OR. A->BASIN_DEST=mvar_basin)

GOTOP

SET FIELDS TO A->PURV_CODE, A->PURV_ID, C->ANN_YEAR, C->ANNUAL_TOT,

A->PURV_NAME, A->TYPE_USE, A->BASIN_SOR, A->BASIN_DEST

RETURN

*** EOF: BASIN_VW.PRG 


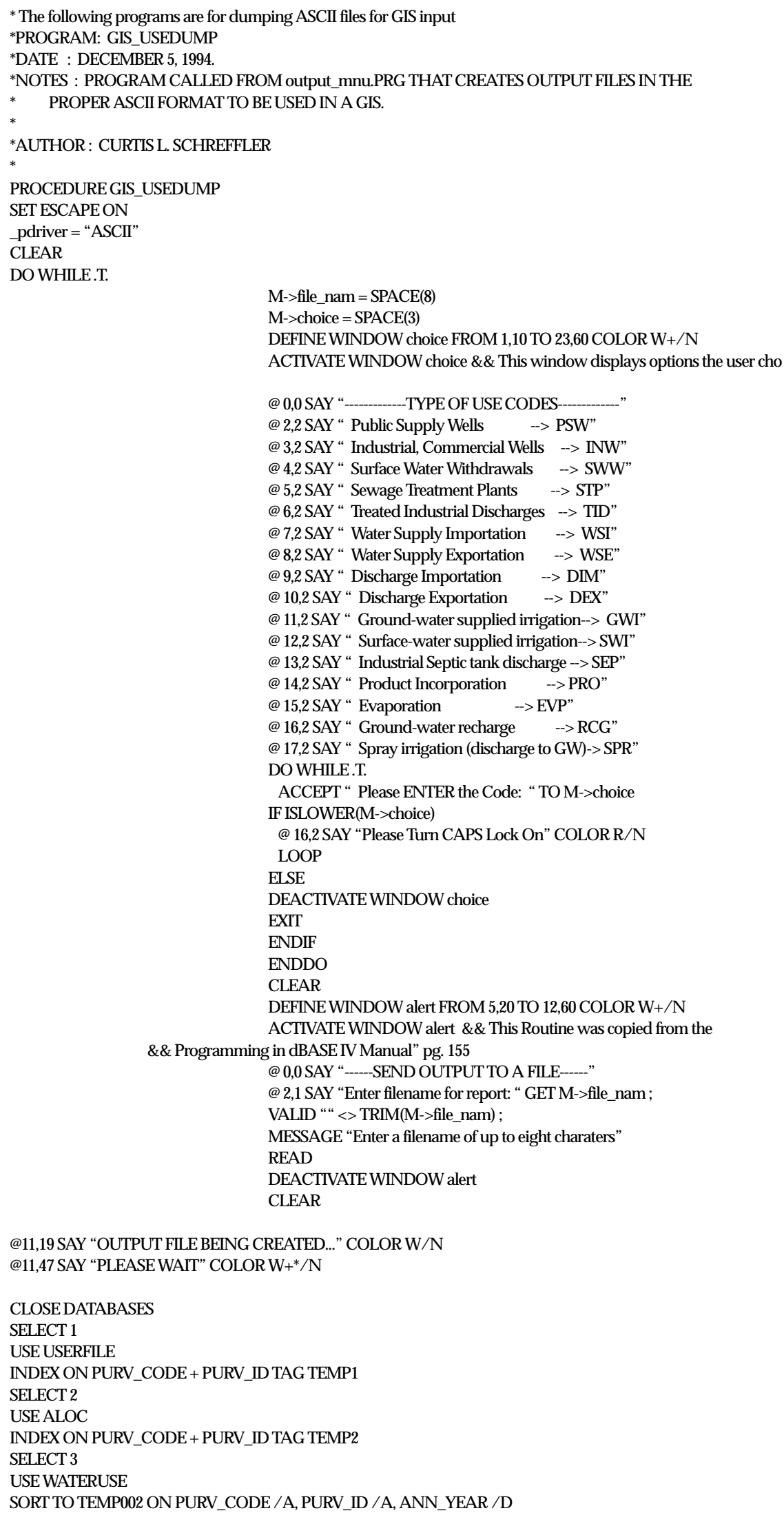




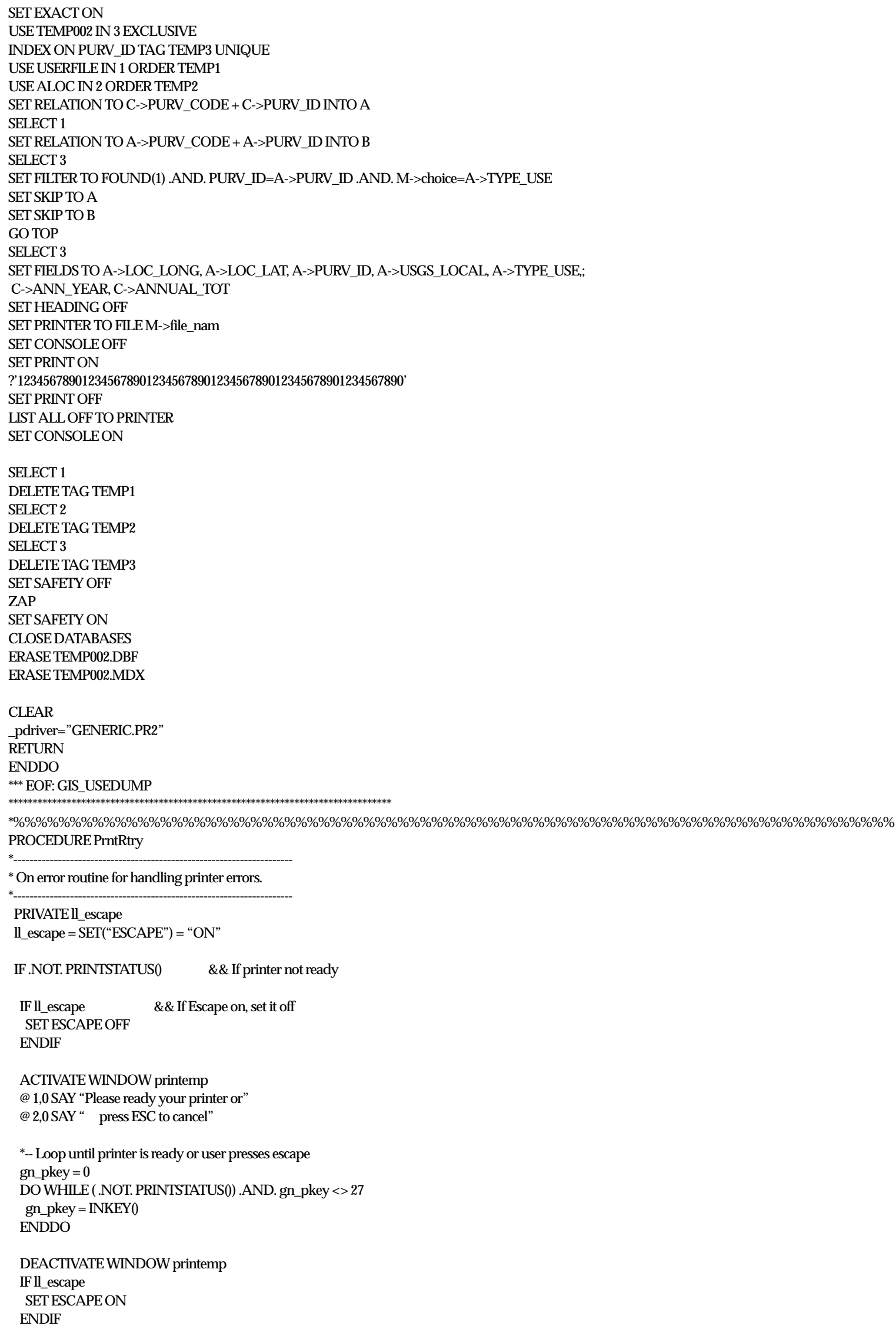




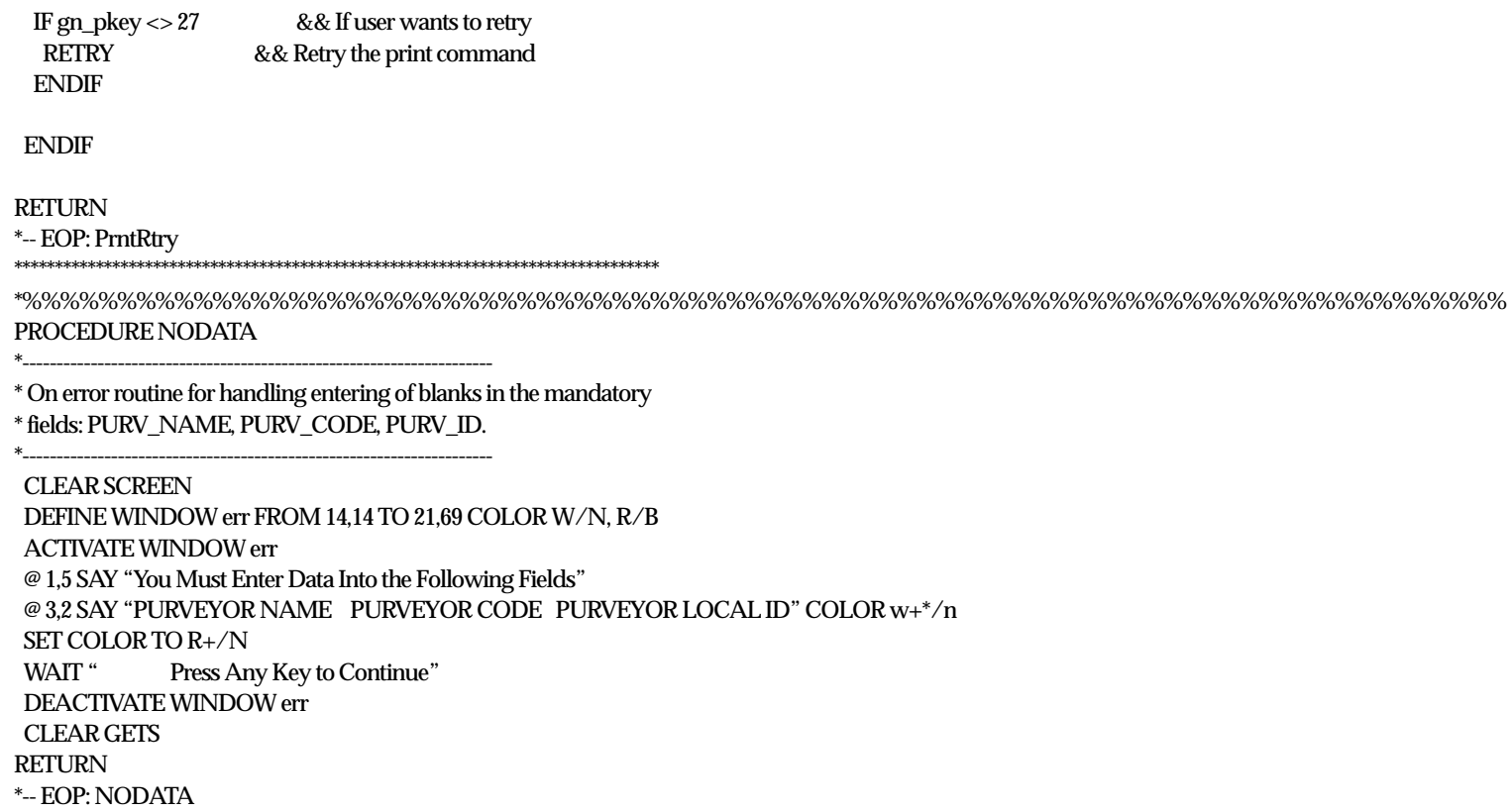




\section{APPENDIX 3. Watershed Water-Use Analysis Program}

\section{(filename analysis.prg)}

*PROGRAM: ANALYSIS.PRG

*DATE : JUNE 8, 1988.

*NOTES : Program called from CONTINUE.PRG.

* User chooses year for computation of water use analysis.

* Computes gw and sw withdrawals, waste water

* $\quad$ discharges, and transfer water. Procedures within this program

* that reside in the Process Library are GWYIELD and GW_COMP. The

* many report forms in this procedure reside in the reports

* directory. The view YEAR_VW sets up the relates and databases.

*AUTHOR: C.L. SCHREFFLER Modified from KAREN VOGEL, 1988

PROCEDURE ANALYSIS

set escape on

DOWHILE.T.

@ 11,15SAY "Choose a year between 1988 and the present year"

@ 12,28 SAY "for computation of the"

@ 13,10 SAY mtitle + "Watershed Water Use Analysis."

@ 14,10SAY" "

INPUT SPACE(23)+"Enter year and press return: 19" TO mvar_yr

CLEAR

STORE 0.0 TO gwtotal, swtotal, totimport, totexport, transtotal, ;

cur_tot, rec_tot, import_cur, import_rec, export_cur, export_rec,

mvar_total, loss_cur, loss_rec, gw_psw, gw_inw, alloc_yr

DOYEAR_VW \&\& The view which sets up the relationships between the \&\& databases and creates the temporary table TEMP001.DBF \&\& Resides in the Process Library.

SET CONSOLEOFF

SET PRINT ON

? SPACE(8)+"WATER USE ANALYSIS FOR “ + mtitle + “ WATERSHED, 19" + STR(mvar_yr,2)

?SPACE $(8)+"$

?SPACE(8)+ “

? SPACE(8)+"Ground Water Withdrawals for " + mtitle + "Watershed, 19" + STR(mvar_yr,2)

?SPACE(8)+" PUBLIC-WATER SUPPLY WELLS

? SPACE $(8)+"$

SET PRINTER OFF

SET CONSOLEON

CLEAR

@ 11,19SAY “COMPUTATION IN PROGRESS..." COLOR W/N

@ 11,45 SAY "PLEASE WAIT" COLOR W+* $\mathrm{N}$

SET CONSOLEOFF

REPORT FORM REPORTS \GWSW NOEJECT FOR TEMP001->ANN_YEAR = STR(mvar_yr,2,0) .AND.;

TEMP001->TYPE_USE $=$ "PSW" .AND. USERFILE->BASIN_SOR $=$ mvar_basin TO PRINTER

IF cur_tot $=0.000$

SET PRINT ON

?" "

? SPACE(30)+"NODATA AVAILABLE"

?" "

SET PRINT OFF

ENDIF

SET PRINT ON

? SPACE $(8)+$

? SPACE(8)+"Ground Water Withdrawals for " + mtitle + "Watershed Most Recent DATA" ?SPACE(8)+" " PUBLIC-WATER SUPPLY WELLS

?SPACE $(8)+"$

SET PRINTER OFF

GOTOTOP

CLEAR

SET CONSOLEON

@ 11,19SAY "COMPUTATION IN PROGRESS..." COLOR W/N

@ 11,45SAY "PLEASE WAIT" COLOR W+*/N 


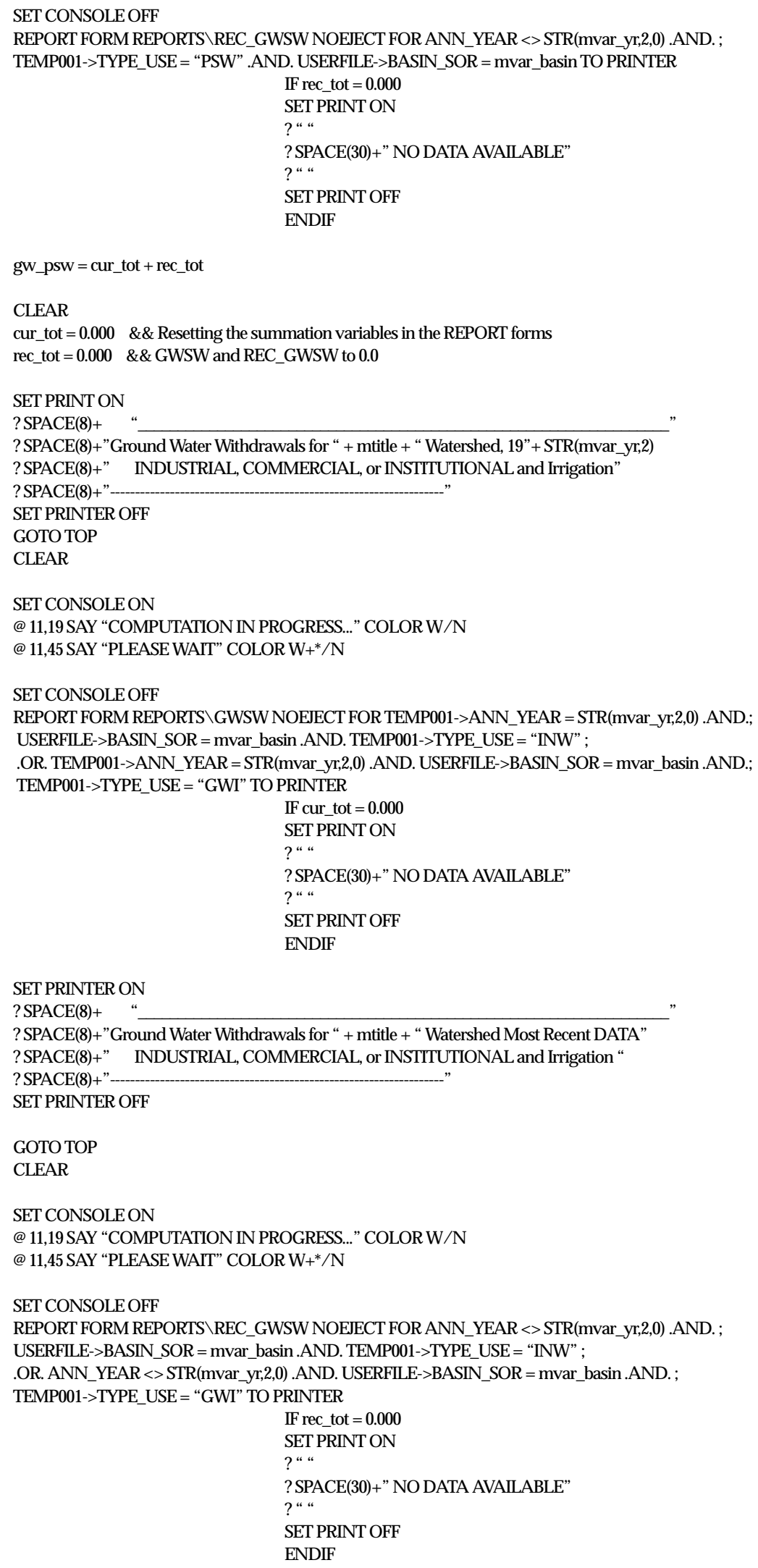




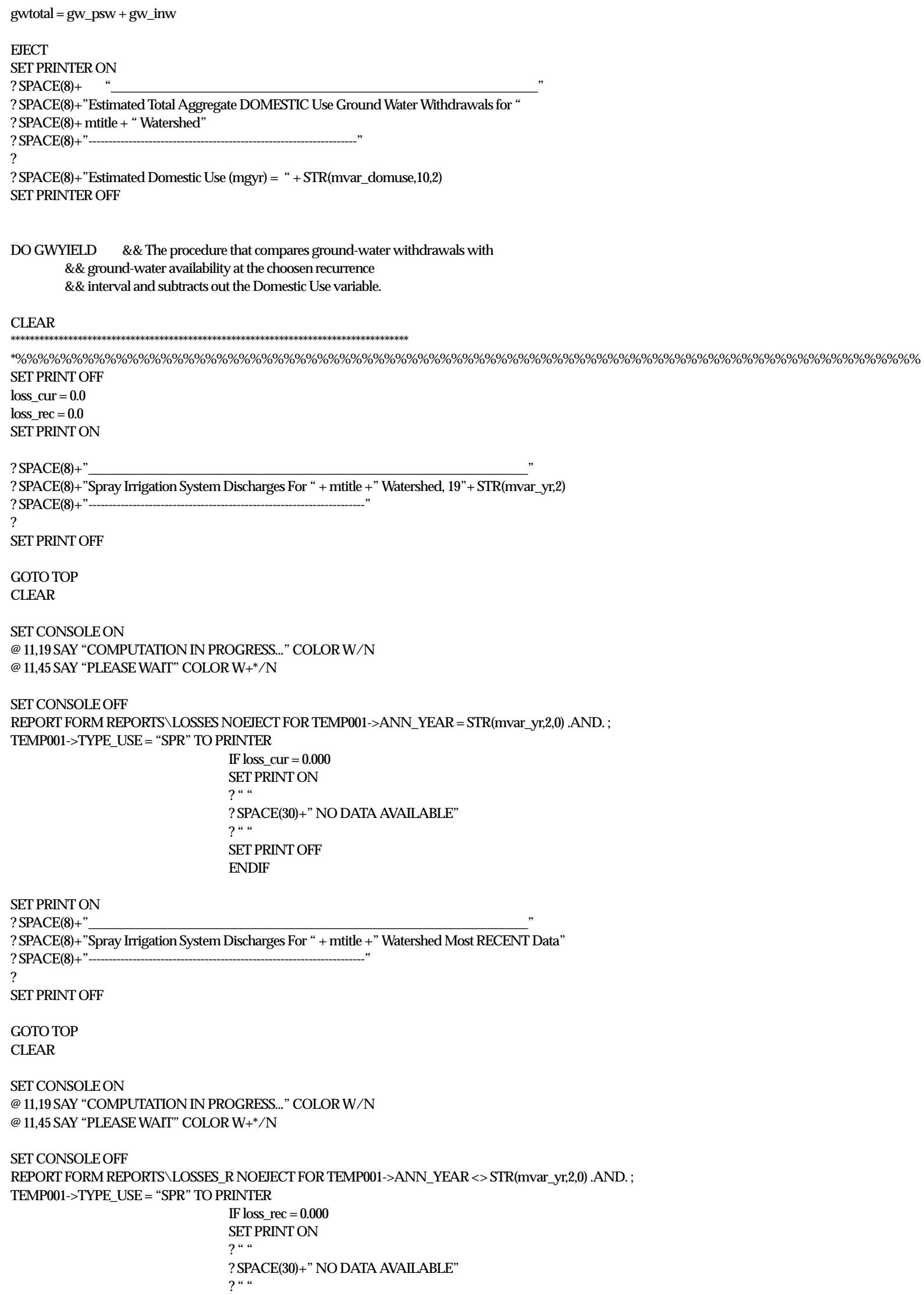


tot_spray $=$ loss_cur + loss_rec

SET PRINT ON

? SPACE (10) + "TOTAL SPRAY IRRIGATION SYSTEM DISCHARGES - " + STR(tot_spray,10,4)

EJECT

CLEAR

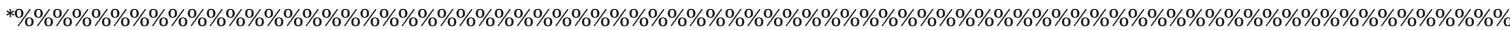

*\%\%\%\%\%\%\%\%\%\%\%\%\%\%\%\%\%\%\%\%\%\%\%\%\%\%\%\%\%\%\%\%\%\%\%\%\%\%\%\%\%\%\%\%\%\%\%\%\%\%\%\%\%\%\%\%\%\%\%\%\%\%\%\%\%\%\%\%\%\%\%\%\%\%\%\%\%\% * SURFACE WATER TOTALING

cur_tot $=0.000 \quad \& \&$ Resetting the summation variables in the REPORT forms

rec_tot $=0.000$ \&\& GWSW and REC_GWSW to 0.0

SET PRINTER ON

? SPACE(8)+"

? SPACE(8)+"Surface Water Withdrawals for " + mtitle +" Watershed, 19"+STR(mvar_yr,2)

? SPACE(8)+"

SET PRINTER OFF

GOTOTOP

CLEAR

SET CONSOLEON

@ 11,19SAY "COMPUTATION IN PROGRESS..." COLOR W/N

@ 11,45 SAY "PLEASE WAIT" COLOR W+*/N

SET CONSOLE OFF

REPORT FORM REPORTS \GWSW NOEJECT FOR TEMP001->ANN_YEAR = STR(mvar_yr,2,0) .AND. ;

TEMP001->TYPE_USE = "SWW" .AND. USERFILE->BASIN_SOR = mvar_basin .OR. ;

TEMP001->ANN_YEAR =STR(mvar_yr,2,0) .AND. USERFILE->BASIN_SOR = mvar_basin .AND. ;

TEMP001->TYPE_USE = "SWI" TOPRINTER

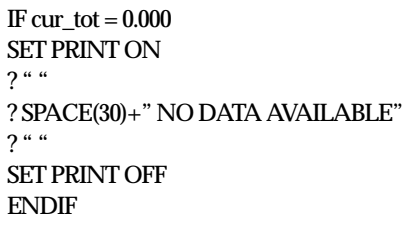

SET PRINTER ON

? $\mathrm{SPACE}(8)+$

? SPACE(8)+"Surface Water Withdrawals for " + mtitle + "Watershed Most Recent DATA"

?SPACE(8)+"-

SET PRINT OFF

GOTOTOP

CLEAR

SET CONSOLEON

@ 11,19 SAY “COMPUTATION IN PROGRESS..." COLOR W/N

@ 11,45 SAY "PLEASE WAIT" COLOR W+*/N

SET CONSOLE OFF

REPORT FORM REPORTS \REC_GWSW NOEJECT FOR ANN_YEAR $<>S T R\left(m v a r \_y r, 2,0\right)$.AND.

TEMP001->TYPE_USE $=$ "SWW" .AND. USERFILE->BASIN_SOR = mvar_basin .OR. ;

ANN_YEAR $<>$ STR $\left(m v a r \_y r, 2,0\right)$.AND. USERFILE->BASIN_SOR = mvar_basin .AND.

TEMP001->TYPE_USE = “SWI" TOPRINTER

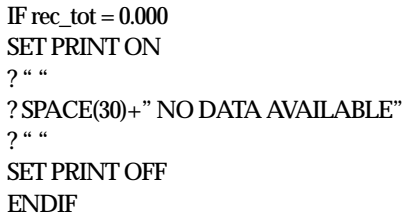

ENDIF

swtotal $=$ cur_tot + rec_tot

SET PRINT ON

? SPACE(10) + “TOTAL SURFACE WATER WITHDRAWALS - “ + STR(swtotal,10,4) 


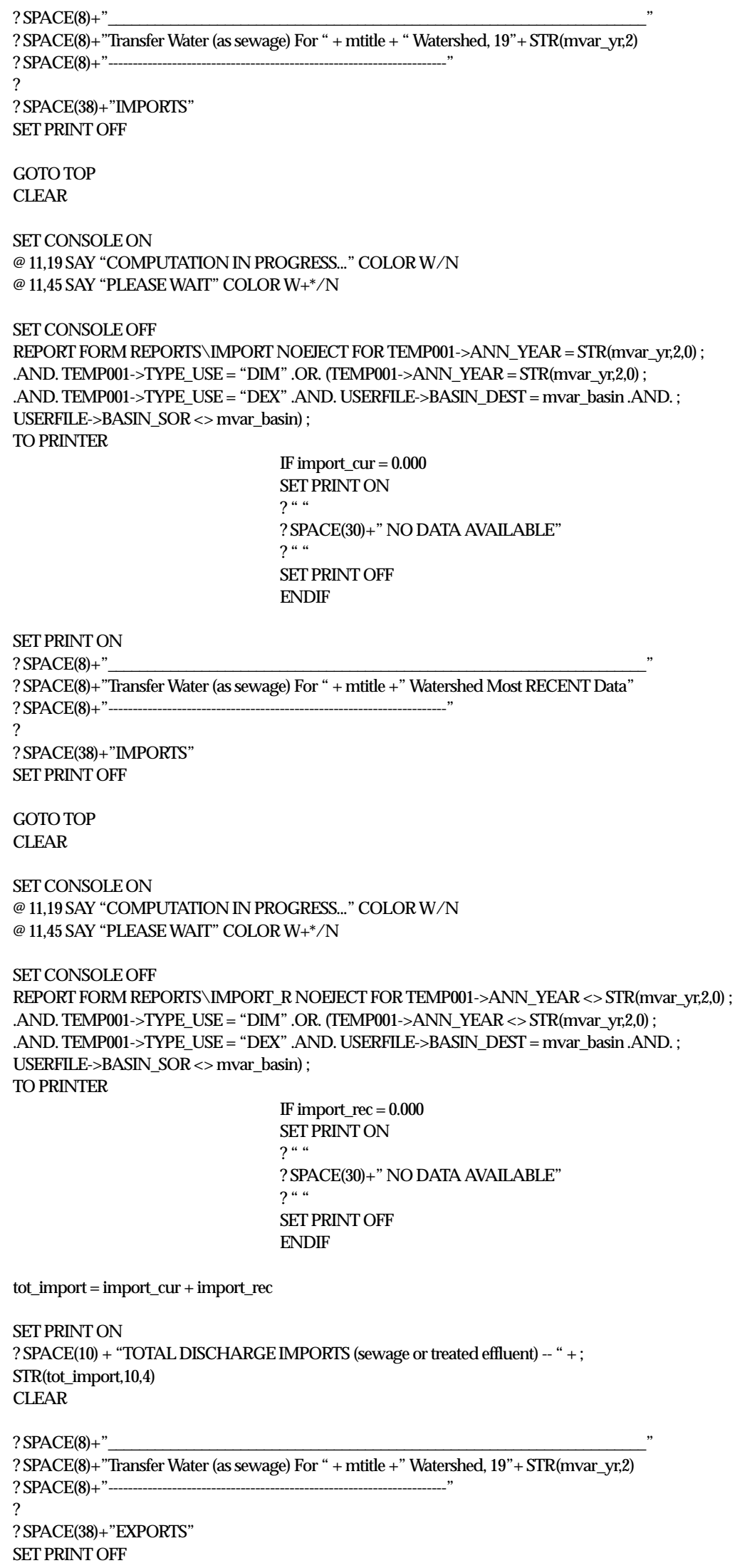




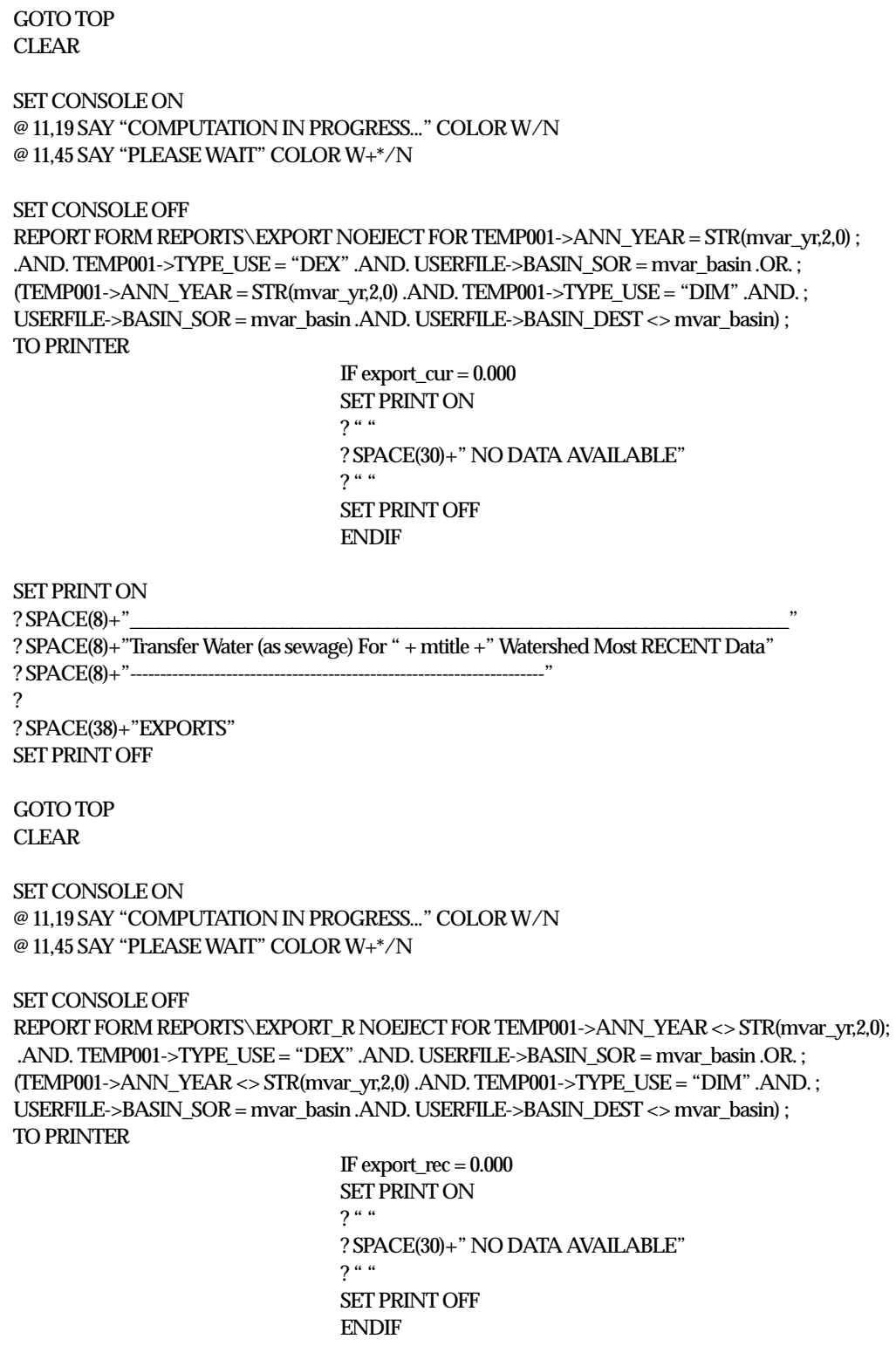




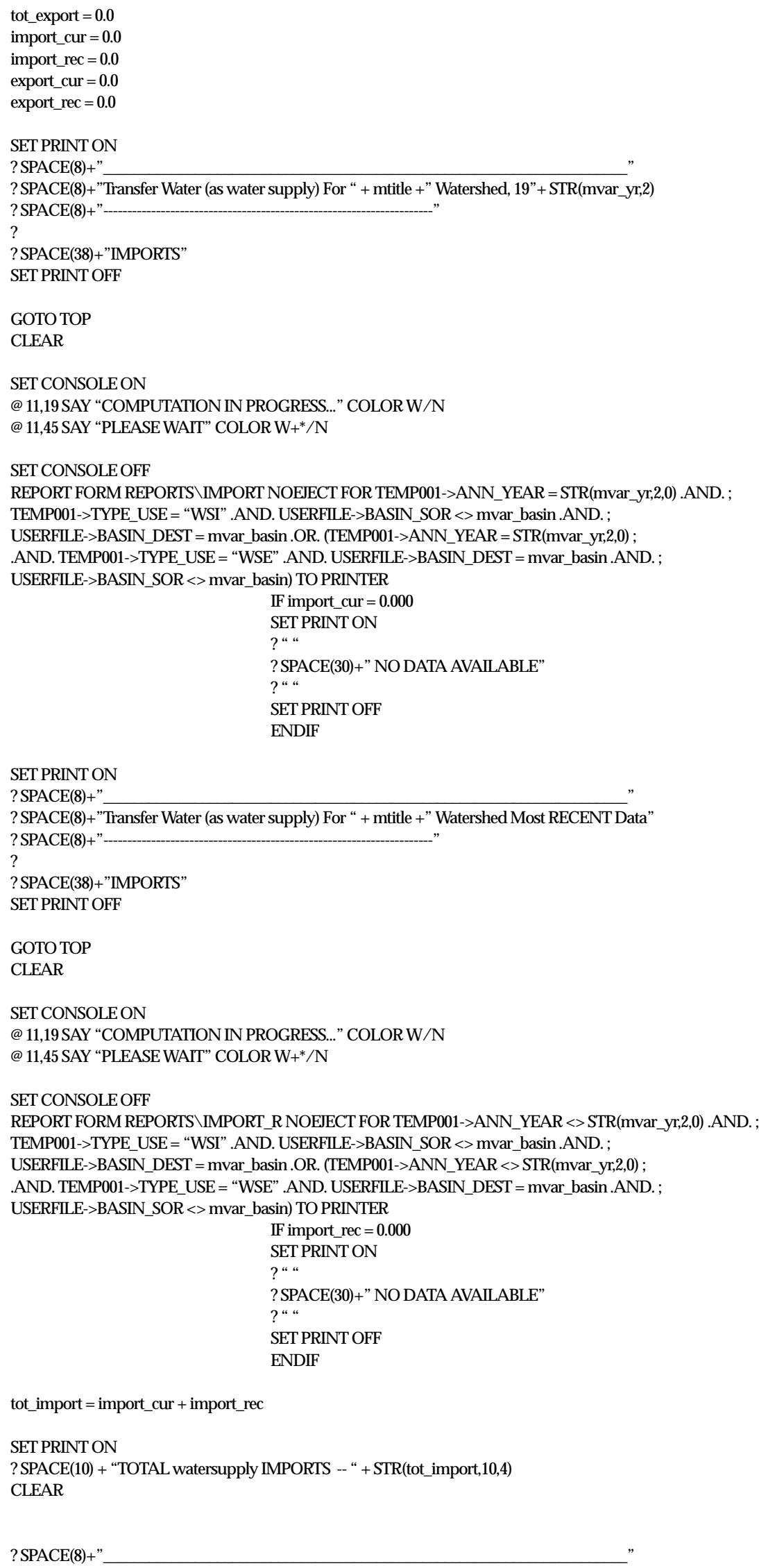




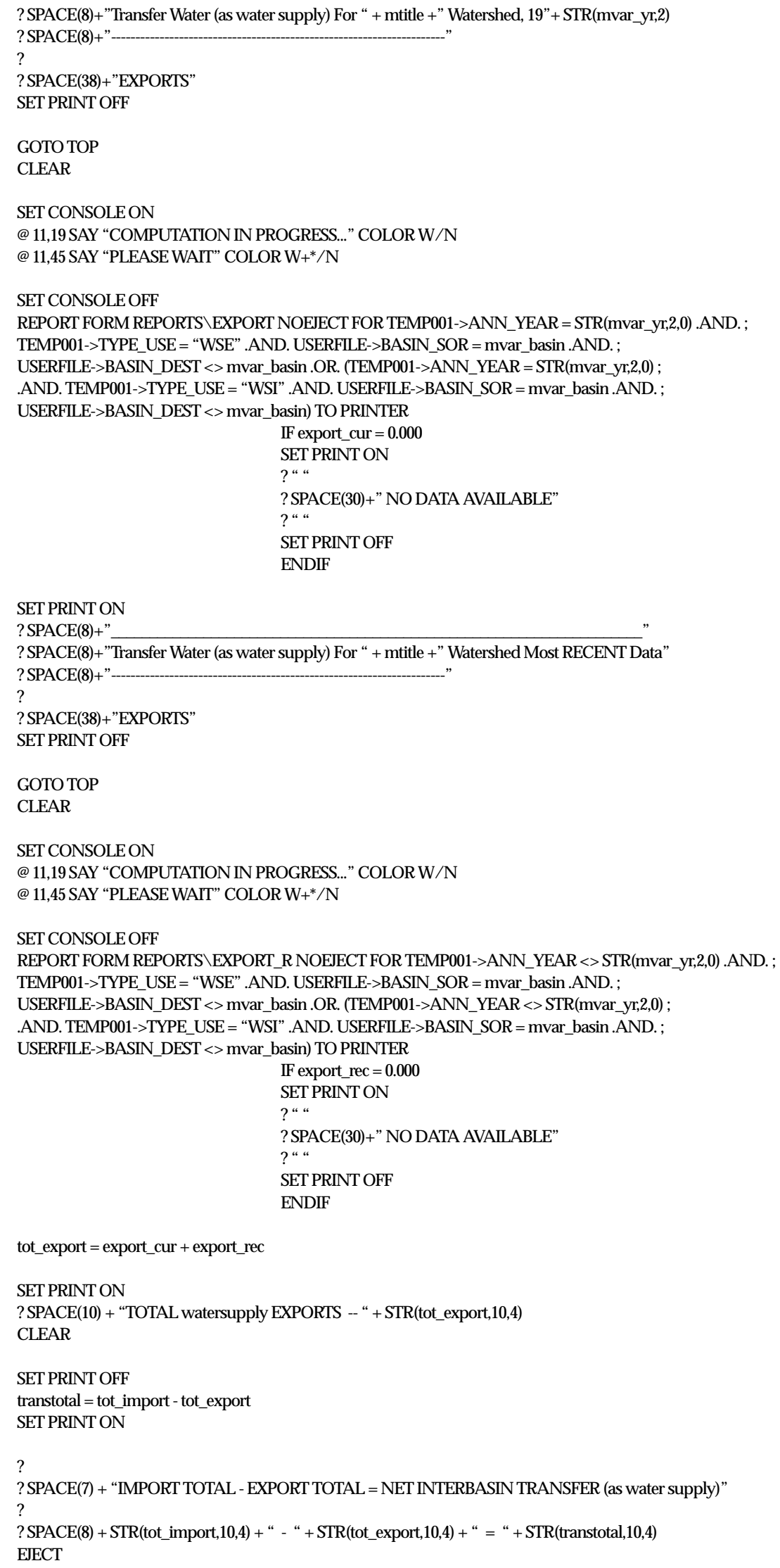




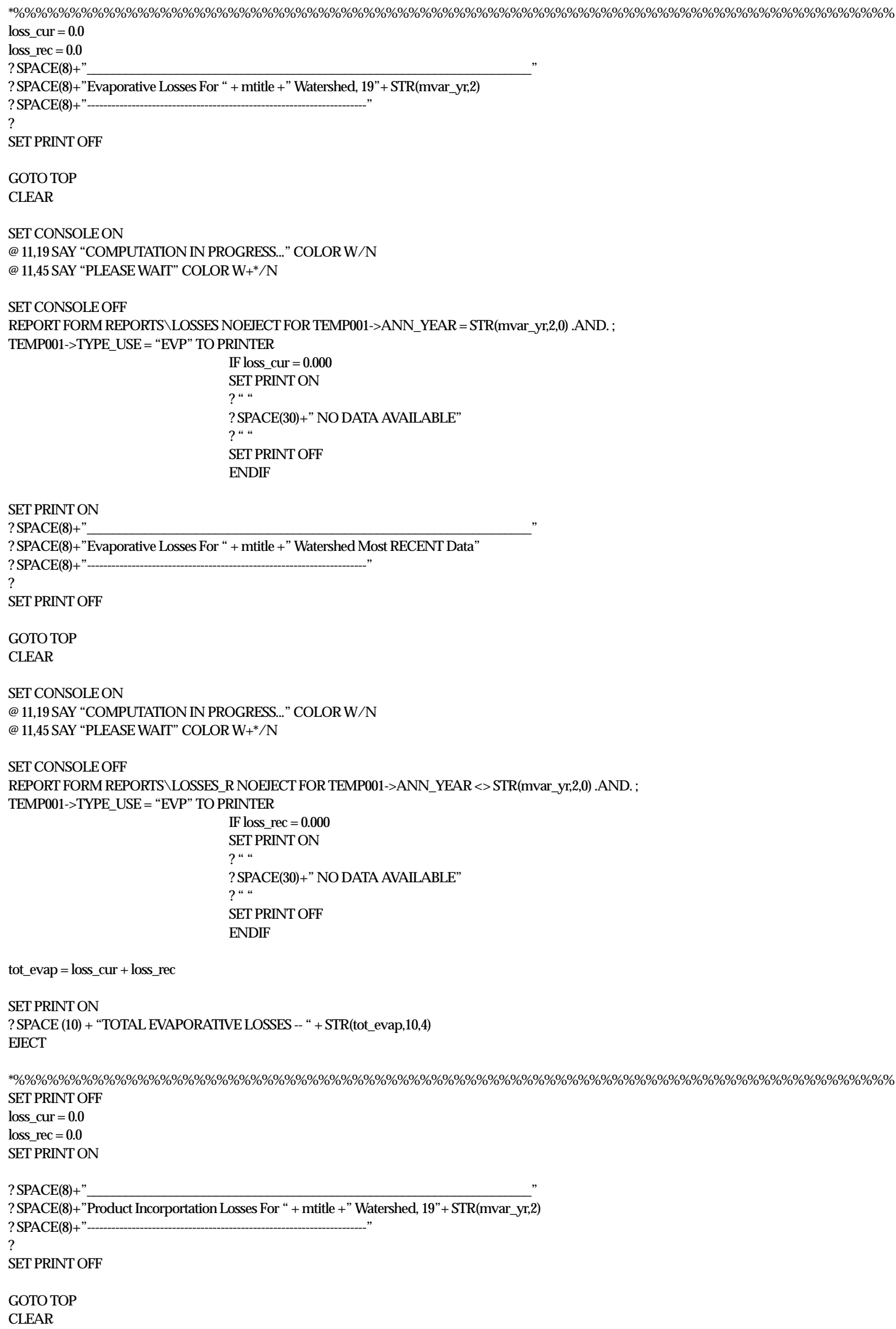




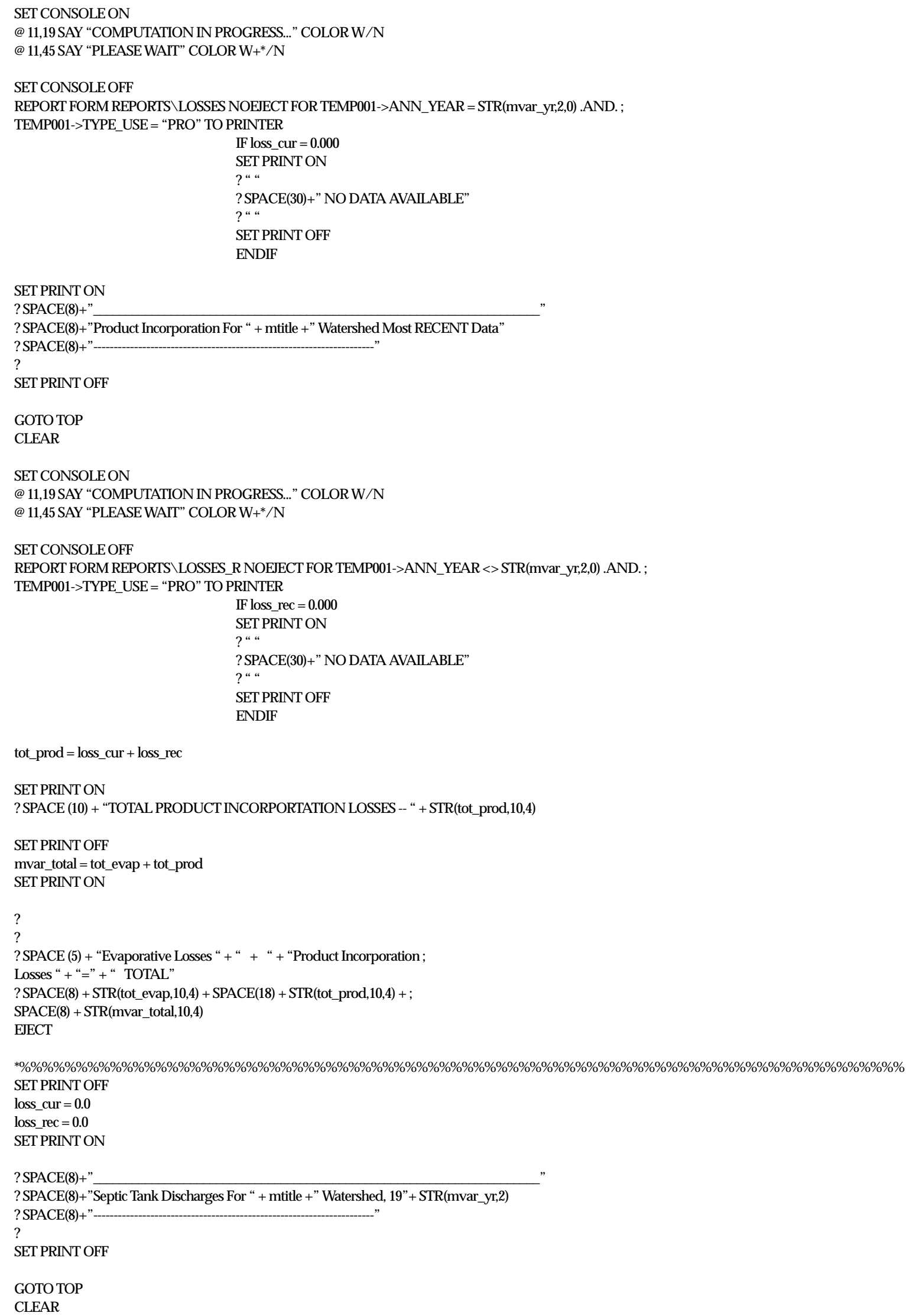




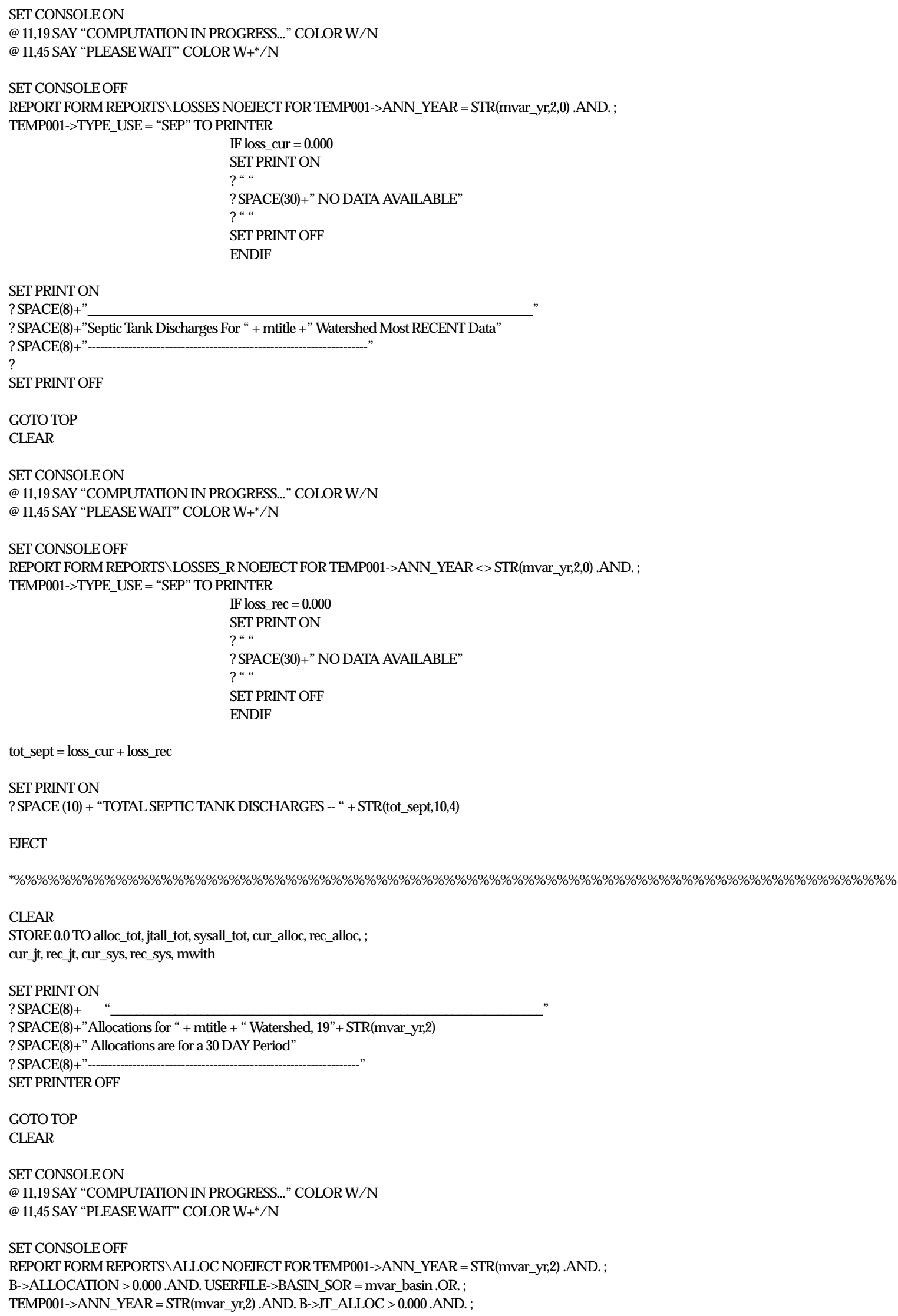


USERFILE->BASIN_SOR = mvar_basin .OR. TEMP001->ANN_YEAR = STR(mvar_yr,2).AND. ;

B->SYS_ALLOC $>0.000$.AND. USERFILE- $>$ BASIN_SOR $=$ mvar_basin TOPRINTER

IF $($ cur_alloc $=0.000$.AND. cur_jt $=0.000$.AND. cur_sys $=0.000)$

SET PRINT ON

?" “

? SPACE(30)+" NODATA AVAILABLE"

?" "

SET PRINT OFF

ENDIF

SET PRINTER ON

? SPACE $(8)+$

?SPACE(8)+"Allocation for " + mtitle + "Watershed Most Recent DATA"

? SPACE(8)+" Allocations are for a 30 DAY Period"

?SPACE(8)+"

SET PRINTER OFF

GOTOTOP

CLEAR

SET CONSOLEON

@ 11,19 SAY “COMPUTATION IN PROGRESS..." COLOR W/N

@ 11,45SAY “PLEASE WAIT” COLOR W+*/N

SET CONSOLE OFF

REPORT FORM REPORTS $\backslash$ ALLOC_RNOEJECT FOR TEMP001->ANN_YEAR <>STR(mvar_yr,2) .AND. ;

B- $>$ ALLOCATION $>0.000$.AND. USERFILE- $>$ BASIN SOR $=$ mvar basin. OR. ;

TEMP001->ANN_YEAR $<>$ STR(mvar_yr,2) .AND. B->JT_ALLOC $>0.000$.AND. ;

USERFILE->BASIN_SOR = mvar_basin .OR. TEMP001->ANN_YEAR $<>$ STR(mvar_yr,2) .AND. ;

B- $>$ SYS_ALLOC $>0.000$.AND. USERFILE->BASIN_SOR $=$ mvar_basin TO PRINTER

IF $($ rec_alloc $=0.000$.AND. rec_jt $=0.000$.AND. rec_sys $=0.000$ )

SET PRINT ON

?" "

? SPACE(30)+"NODATA AVAILABLE"

?"“

SET PRINT OFF

ENDIF

alloc_tot $=$ cur_alloc + rec $\_$alloc

jtall_tot $=$ cur_jt + rec_jt

sysall_tot $=$ cur_sys + rec_sys

alloc_yr $=$ alloc_tot $*(365 / 30) \quad \& \&$ To annualize the 30 Day Allocation data

DOGW_COMP \&\&Procedure that compares Allocations with Availability

\&\& and Withdrawals of ground- and surface-water.

CLEAR

SET PRINT OFF

RETURN

ENDDO 


\section{APPENDIX 4. Water-Use Analysis Report for Little Neshaminy Creek, Warminster Subbasin}

WATER USE ANALYSIS FOR Warminster Subbasin Little Neshaminy WATERSHED, 1992

Ground Water Withdrawals for Warminster Subbasin Little Neshaminy Watershed, 1992 PUBLIC-WATER SUPPLY WELLS

Page No. 1

01/19/95

CODE Water User

Withdrawn

100230 CHRISTS HOME WELL\# 1

Amount (mgal)

100230 CHRISTS HOME WELL\#

3.1890

0.0000

101921 HORSHAM TWP WATER AUTHORITY WELL\#10 $\quad 12.5000$

101254 NORTHAMPTON BUCKS COMUN A-WELL \#12 0.0000

101262 WARRINGTON TWPMUN AUTH WELL\#1 44.7800

101262 WARRINGTON TWP MUN AUTH WELL\#2 $\quad 43.2600$

101262 WARRINGTON TWP MUN AUTH WELL\#3 60.0000

101262 WARRINGTON TWP MUN AUTH WELL\#4 26.3600

101262 WARRINGTON TWP MUN AUTH WELL\#5 53.5800

101262 WARRINGTON TWP MUN AUTH WELL \#6 12.4800

101262 WARRINGTON TWP MUN AUTH WELL\#9 72.7600

101237 WARMINSTER TWP MUN AUTH WELL\#4 42.4200

101237 WARMINSTER TWP MUN AUTH WELL\#5 $\quad 78.5700$

101237 WARMINSTER TWP MUN AUTH WELL\#6 43.8800

101237 WARMINSTER TWP MUN AUTH WELL\#9 137.3000

101237 WARMINSTER TWP MUN AUTH WELL\#10 134.4300

101237 WARMINSTER TWP MUN AUTH WELL\#13 $\quad 24.4800$

101237 WARMINSTER TWP MUN AUTH WELL\#14

101237 WARMINSTER TWP MUN AUTH WELL\#15 93.3000

101237 WARMINSTER TWP MUN AUTH WELL \#26 92.9300

101237 WARMINSTER TWP MUN AUTH WELL\#36 38.3400

101237 WARMINSTER TWP MUN AUTH WELL\#3 144.3000

101237 WARMINSTER TWP MUN AUTH WELL \#39 56.5400

$\begin{array}{ll}* * * \text { Total }^{* *} & 1258.5390\end{array}$

Ground Water Withdrawals for Warminster Subbasin Little Neshaminy Watershed Most Recent DATA PUBLIC-WATER SUPPLY WELLS

Page No. 1

$01 / 19 / 95$

\begin{tabular}{|c|c|c|}
\hline Water User & $\begin{array}{l}\text { Year } \\
\text { of } \\
\text { Data }\end{array}$ & $\begin{array}{l}\text { Withdrawn } \\
\text { Amount (mgal) }\end{array}$ \\
\hline 101237 WARMINSTER TWP MUNIC AUTH WELL 23A & 90 & 0.0000 \\
\hline 101237 WARMINSTER TWP MUNIC AUTH WELL 23B & 90 & 0.0000 \\
\hline 101237 WARMINSTER TWP MUN AUTH WELL $\# 24$ & 90 & 0.0000 \\
\hline$* * *$ Total $* * *$ & & 0.0000 \\
\hline
\end{tabular}

Ground Water Withdrawals for Warminster Subbasin Little Neshaminy Watershed, 1992 INDUSTRIAL, COMMERCIAL, or INSTITUTIONAL and Irrigation

Page No. 1

$01 / 19 / 95$

CODE Water User Withdrawn

Amount (mgal)

450053 FEENEYSNURSERY WELL W2

018508 JN WAGNER \& SONS INC-WELL \#1

018508 JN WAGNER \& SONS INC-WELL \#2

100159 NAVAL AIR DEV CTR WELL\#3

3.2400

6.4440

0.4060

5.9530

3.0710

100159 NAVAL AIR DEV CTR WELL\#10 $\quad 35.5780$

250003 SPRING MILL COUNTRY CLUB WELL\#1 2.2530

250003 SPRING MILL COUNTRY CLUB WELL\#2 0.8460

*** Total *** 57.7910

Ground Water Withdrawals for Warminster Subbasin Little Neshaminy Watershed Most Recent DATA

INDUSTRIAL, COMMERCIAL, or INSTITUTIONAL and Irrigation 
Page No. 1

01/19/95

Withdrawn

021167 AMERICAN BROCHURE--WITHDRAW WELL

005945 ATCH-MONT GEAR INC

018949 R M C INC.- WITHDRAW WELL

018936 BALDWIN PRINTING-WITHDRAW WELL

020822 BENNETT HEAT TREATING - WITH WELL

016856 CAROLINCH CO

016854 COMPUSTATICSINC

020862 CRANE CO - WITHDRAW WELL

005949 CROCKETT MACHINE CO

005938 CURRAN MFG CO.- WITHDRAW WELL

016839 DELVCO INDS INC

020826 DELAWARE VALLEY PRODUCTS-WITH WELL 016851 DA-TECH CORP - WITHDRAW WELL

006194 DENTRONIXINC

020817 EHMCO INC - WITHDRAW WELL

020819 E \&J METAL FABRICATORS-WITH WELL

020856 ELECTRONIC DEVELOPMENT-WITHDR WELL

016858 ESSEX ENGINEERING - WITHDRAW WELL

018326 FORANNE MFG INC.- WITHDRAW WELL

005941 FELCO MFG CO.- WITHDRAW WELL

016865 FLUITRON INC - WITHDRAW WELL

006375 FOX RUN CRAFTSMEN - WITHDRAW WELL

006378 FRANKLIN INSTRUMENT- WITHDRAW WELL

006518 GAUSS SYSTEMS \& CONTROLS

020821 G S C INC - WITHDRAW WELL

450061 HAIST MATT A GROUND WITHDRAWAL

005948 HAHN \& KAISER-WITHDRAW WELL

$020818 \mathrm{H} \&$ R INDUSTRIES INC -WITHDRAW WELL

005935 INDUSTRIAL NAME PLATE-WITHDR WELL

006470 INNOVATIVE MEDICAL SYSTEM-WITH WELL

018316 J ANOR WIRE \& CABLE-WITHDRAW WELL

016861 I M CHEM FEED \& CONTROL SYS

006474 J OMAC INC.- WITHDRAWAL WELL

005936 KAR-GO DECAL CO.- WITHDRAW WELL

018953 KING-GUTHRIE CO.- WITHDRAW WELL

$006452 \mathrm{~K} \&$ W MACHINE CO.- WITHDRAW WELL

020858 KOSMA TOOL \& DIE - WITHDRAW WELL

020825 KOVACS MFG CO - WITHDRAW WELL

020859 KRUSE TOOL \& DIE INC -WITHDRAW WELL

020824 KINETIC TOOL CO - WITHDRAW WELL

005946 LAMINAR FLOW INC.- WITHDRAW WELL

018947 LIFTEX INC.- WITHDRAW WELL

018975 LEGENDARY CORVETTE-WITHDRAW WELL

018957 MANSCO PRODUCTS INC.-WITHDRAW WELL

006471 METAL CRAFTERS INC

020860 MEDL TOOL \& DIE INC - WITHDRAW WELL

006488 METCO MFG CO INC - WITHDRAW WELL

020816 MID ATLANTIC CIRCUIT INC- WITH WELL

005944 MILTON ROY CO HARTELL DIV

016853 M T I CORP - WITHDRAW WELL

020823 NEU DYNAMICS CORP - WITHDRAW WELL

020864 NEWTOWN TOOL \& MFG CO INC-WITH WELL

006442 NUCLEAR RESEARCH-WITHDRAW WELL

100159 NAVAL AIR DEV CTR WELL \#5

100159 NAVAL AIR DEV CTR WELL\#

016860 OMNI ELECS \& MFG INC

006311 PACKAGING SERVICE- WITHDRAW WELL

005950 PIONEER TOOL DIE \& MACH - WITH WELL

Page No. 2

$01 / 19 / 95$

CODE Water User

Year

$88 \quad 0.0025$

$77 \quad 0.0325$

$84 \quad 0.0375$

0.0118

0.2299

0.0750

0.1125

1.0842

0.0450

0.0030

0.1040

0.0850

0.1200

0.1014

0.0360

0.0200

0.0001

0.0260

0.1476

0.0195

0.1404

0.2063

0.0858

0.0104

0.0499

0.4656

0.0078

0.0349

0.0190

0.3120

0.0749

0.1001

0.2808

0.5200

0.0300

0.0117

0.0060

0.0350

0.2800

0.0113

0.0563

0.0858

0.0507

0.0150

0.0470

0.0140

0.3203

0.0120

0.1560

0.0699

0.0180

0.0400

0.2912

0.0000

0.0000

0.0383

0.0234

Withdrawn

Amount (mgal)

of

Data

0.3640

0.0540

0.1500

0.0200

0.0400

0.4290

0.4992

0.0390

0.0907

0.0842 


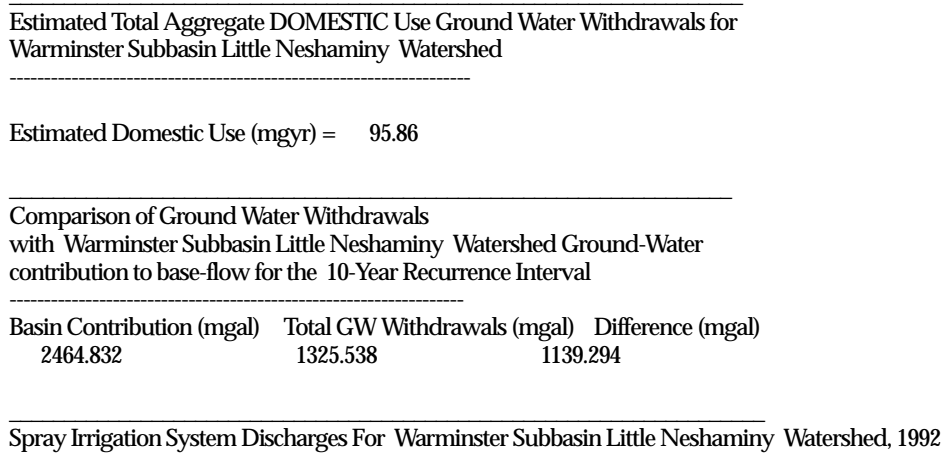




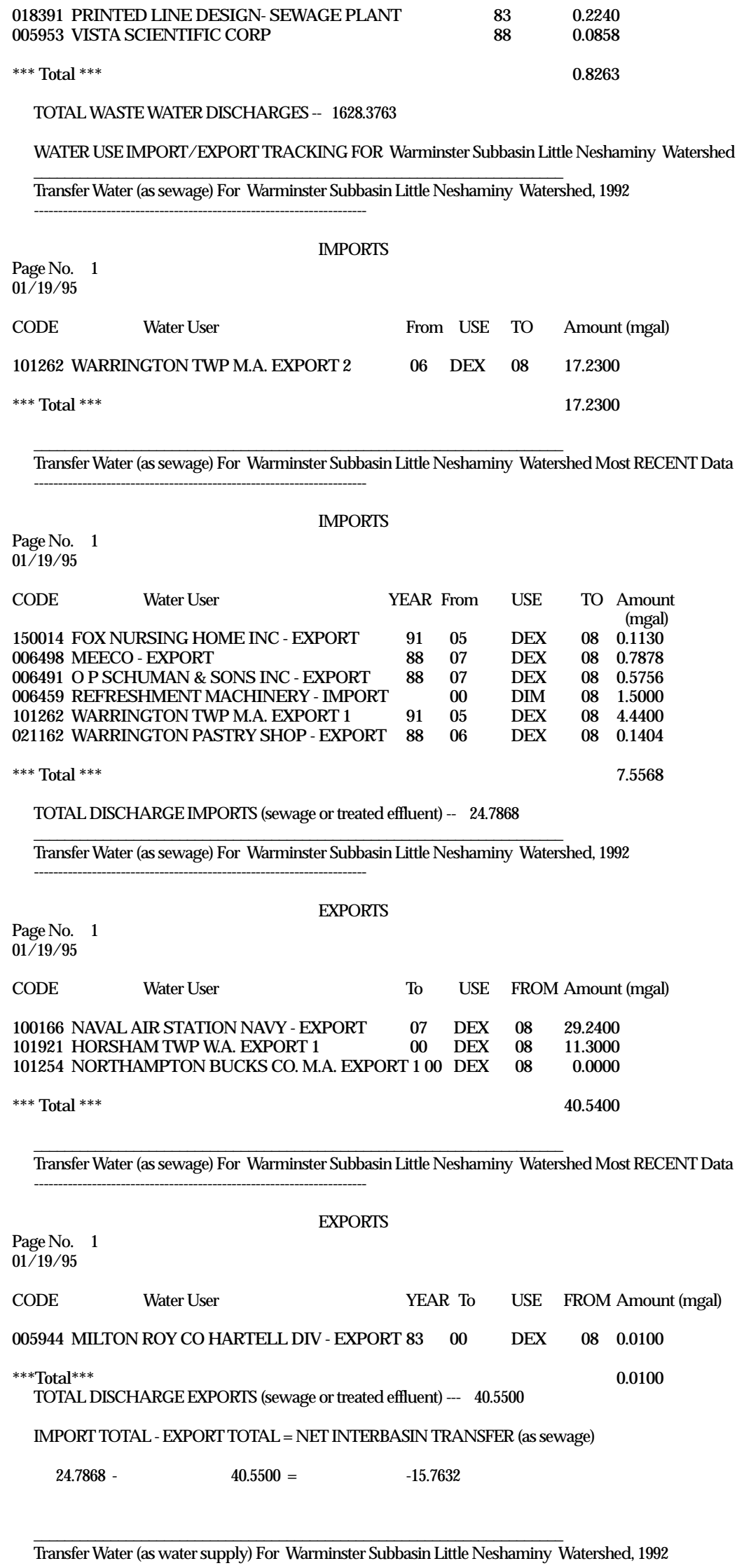




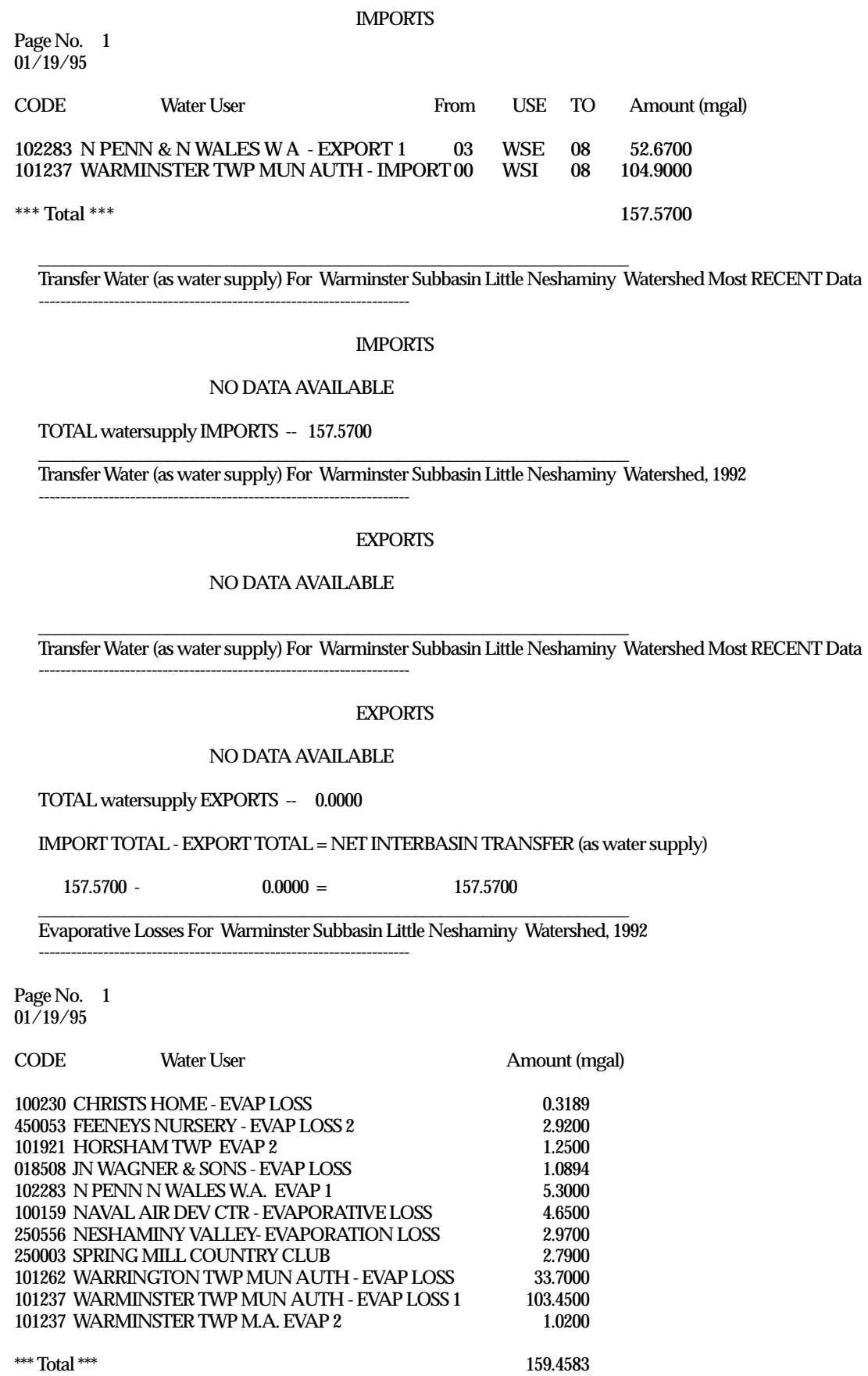




$\begin{array}{lll}\text { 006474 J OMAC INC - EVAP LOSS } & 88 & 0.0100 \\ \text { 005936 KAR-GO DECAL CO.- EVAPORATION LOSS } & 84 & 0.0052 \\ \text { 006471 METAL CRAFTERS INC } & 83 & 0.0015 \\ \text { 006488 METCO MFG CO INC - EVAP LOSS } & 88 & 0.0161 \\ \text { 020816 MID ATLANTIC CIRCUIT INC-EVAP LOSS } & 88 & 0.0010 \\ \text { 005944 MILTON ROY CO HARTELL DIV - EVAP LOSS } & 83 & 0.0160 \\ \text { 006442 NUCLEAR RESEARCH - EVAP LOSS } & 88 & 0.0291 \\ \text { 018391 PRINTED LINE DESIGN - EVAP LOSS } & 83 & 0.0360 \\ \text { 006374 TUBRO COMPANY INCORPORATED - EVAP LOSS } & 88 & 0.0499 \\ \text { 006497 WARRINGTON EQUIPMENT - EVAP LOSS } & 88 & 0.0325 \\ \text { *** Total *** } & & \\ \end{array}$

TOTALEVAPORATIVE LOSSES - 160.5324

Product Incorportation Losses For Warminster Subbasin Little Neshaminy Watershed, 1992

Page No. 1

$01 / 19 / 95$

CODE

Water User

Amount (mgal)

018508 JN WAGNER \& SONS - PROD CONS $\quad 2.1788$

*** Total ${ }^{* * *} \quad 2.1788$

Product Incorporation For Warminster Subbasin Little Neshaminy Watershed Most RECENT Data

Page No. 1

$01 / 19 / 95$

CODE Water User

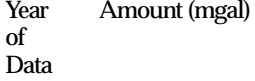

005945 ATCH-MONT GEAR INC

018936 BALDWIN PRINTING-PRODUCT CONSUMP

006518 GAUSS SYSTEMS \& CONTROLS

020816 MID ATLANTIC CIRCUIT INC -PROD CONS

006480 REBLING PLASTICS CO - PROD CONS

005953 VISTA SCIENTIFIC CORP - PROD CONS

*** Total ***

$77 \quad 0.0014$

$83 \quad 0.0001$

0.0003

0.0007

0.0020

0.0020

0.0047

0.0112

TOTAL PRODUCT INCORPORTATION LOSSES -- 2.1900

Evaporative Losses + Product Incorporation Losses $=$ TOTAL

$160.5324+\quad 2.1900=\quad 162.7224$

Septic Tank Discharges For Warminster Subbasin Little Neshaminy Watershed, 1992

NODATA AVAILABLE

Septic Tank Discharges For Warminster Subbasin Little Neshaminy Watershed Most RECENT Data

Page No. 1

01/19/95

CODE Water User

Year Amount (mgal)

of

021167 AMERICAN BROCHURE--ON-LOT SEPTIC

005945 ATCH-MONT GEAR INC

018949 R M C INC.- ON-LOT SEPTIC

018936 BALDWIN PRINTING-ON-LOT SEPTIC

020822 BENNETT HEAT TREATING - SEPTIC

016856 CAROLINCH CO

016854 COMPUSTATICSINC

005949 CROCKETT MACHINE CO

005938 CURRAN MFG CO.- ON-LOT SEPTIC

016839 DELVCO INDSINC

020826 DELAWARE VALLEY PRODUCTS - SEPTIC

$\begin{array}{ll}88 & 0.0025 \\ 77 & 0.0309 \\ 84 & 0.0375 \\ 83 & 0.0117 \\ 88 & 0.0499 \\ 83 & 0.0750 \\ 83 & 0.1125 \\ 83 & 0.0450 \\ 88 & 0.0027 \\ 83 & 0.1040 \\ 88 & 0.0850\end{array}$


016851 DA-TECH CORP - ON LOT SEPTIC

006194 DENTRONIXINC

020817 EHMCO INC - ON LOT SEPTIC

020819 E \& J METAL FABRICATORS INC-SEPTIC

020856 ELECTRONIC DEVELOPMENT - SEPTIC

016858 ESSEX ENGINEERING - ON LOT SEPTIC

018326 FORANNE MFG INC.- ON-LOT SEPTIC

005941 FELCO MFG CO.-ON-LOT SEPTIC

016865 FLUITRON INC - ON LOT SEPTIC

006375 FOX RUN CRAFTSMEN - ON LOT SEPTIC

006378 FRANKLIN INSTRUMENT- ON-LOT SEPTIC

020821 G S C INC - ON LOT SEPTIC

005948 HAHN \& KAISER-ON-LOT SEPTIC

$020818 \mathrm{H} \& \mathrm{R}$ INDUSTRIES INC - SEPTIC

005935 INDUSTRIAL NAME PLATE-ON-LOT SEPTC

006470 INNOVATIVE MEDICAL SYSTEMS - SEPTIC

018316 J ANOR WIRE \& CABLE-ON-LOT SEPTIC

016861 I M CHEM FEED \& CONTROL SYS

020861 J M MACHINE - ON LOT SEPTIC

006474 J OMAC INC.- ON-LOT SEPTIC

005936 KAR-GO DECAL CO.- ON-LOT SEPTIC

018953 KING-GUTHRIE CO.- ON-LOT SEPTIC

020858 KOSMA TOOL \& DIE - ON LOT SEPTIC

020825 KOVACS MFG CO - ON LOT SEPTIC

020859 KRUSE TOOL \& DIE INC - SEPTIC

020824 KINETIC TOOL CO - ON LOT SEPTIC

005946 LAMINAR FLOW INC.- ON-LOT SEPTIC

018947 LIFTEX INC - ON-LOT SEPTIC

018975 LEGENDARY CORVETTE-ON-LOT SEPTIC

018957 MANSCO PRODUCTS INC.-ON-LOT SEPTIC

006471 METAL CRAFTERS INC

020860 MEDL TOOL \& DIE INC - ON LOT SEPTIC

006488 METCO MFG CO INC - ON LOT SEPTIC

020816 MID ATLANTIC CIRCUIT INC - SEPTIC

005944 MILTON ROY CO HARTELL DIV

016853 M T I CORP - ON LOT SEPTIC

020823 NEU DYNAMICS CORP - ON LOT SEPTIC

020864 NEWTOWN TOOL \& MFG COINC - SEPTIC

006442 NUCLEAR RESEARCH-ON-LOT SEPTIC

016860 OMNI ELECS \& MFG INC

006311 PACKAGING SERVICES-ON-LOT SEPTIC

005950 PIONEER TOOL DIE \& MACH CO - SEPTIC

018391 PRINTED LINE DESIGN-ON-LOT SEPTIC

006480 REBLING PLASTICS CO - ON LOT SEPTIC

016847 REIF, M M \& CO

020820 S K S EQUIPMENT COMPANY - SEPTIC

006318 TECHNICAL GLASS PRODUCTS - SEPTIC

Page No. 2

$01 / 19 / 95$

CODE Water User

016677 TINIUS OLSEN - SEPTIC

006374 TUBRO COMPANY-ON-LOT SEPTIC

018954 UNITED CIRCUITS INC.- ON-LOT SEPTIC

016857 WARREN MCH COINC

006497 WARRINGTON EQUIPMENT-ON-LOT SEPTIC

005932 WORLD FLAVORS-ON-LOT SEPTIC

020863 WESLEY M J OHNSON INC -ON LOT SEPTIC

Data

$* * *$ Total ***

0.1200

0.1014

0.0360

0.0200

0.0001

0.0260

0.1476

0.0195

0.1404

0.2063

0.0858

0.0499

0.0078

0.0349

0.0190

0.2810

0.0749

0.1001

0.0050

0.2688

0.5148

0.0300

0.0060

0.0350

0.2800

0.0113

0.0563

0.0858

0.0507

0.0150

0.0456

0.0140

0.3060

0.0040

0.1300

0.0699

0.0180

0.0400

0.2620

0.0383

0.0975

0.0234

0.1040

0.0520

0.1500

0.0200

0.0400

TOTAL SEPTIC TANK DISCHARGES - 6.8973

Allocations for Warminster Subbasin Little Neshaminy Watershed, 1992 Allocations are for a 30 DAY Period

Page No. 1

01/19/95

CODE

Water User

Allocation

101921 HORSHAM TWP WATER AUTHORITY WELL\#10 6.380

101254 NORTHAMPTON BUCKS CO MUN A-WELL \#12 12.960

101262 WARRINGTON TWP MUN AUTH WELL\#1

101262 WARRINGTON TWP MUN AUTH WELL\#2 6.800

101262 WARRINGTON TWP MUN AUTH WELL\#3 8.400

101262 WARRINGTON TWP MUN AUTH WELL\#4 3.950 
$\begin{array}{lr}101262 \text { WARRINGTON TWP MUN AUTH WELL\#5 } & 9.760 \\ 101262 \text { WARRINGTON TWP MUN AUTH WELL\#6 } & 1.500 \\ 101262 \text { WARRINGTON TWP MUN AUTH WELL\#8 } & 2.720 \\ 101262 \text { WARRINGTON TWP MUN AUTH WELL\#9 } & 6.270 \\ 101237 \text { WARMINSTER TWP MUN AUTH WELL\#4 } & 5.610 \\ 101237 \text { WARMINSTER TWP MUN AUTH WELL\#5 } & 6.080 \\ 101237 \text { WARMINSTER TWP MUN AUTH WELL\#6 } & 2.800 \\ 101237 \text { WARMINSTER TWP MUN AUTH WELL\#9 } & 8.420 \\ 101237 \text { WARMINSTER TWP MUN AUTH WELL\#10 } & 8.420 \\ 101237 \text { WARMINSTER TWP MUN AUTH WELL\#13 } & 2.620 \\ 101237 \text { WARMINSTER TWP MUN AUTH WELL\#14 } & 4.110 \\ 101237 \text { WARMINSTER TWP MUN AUTH WELL\#15 } & 6.540 \\ 101237 \text { WARMINSTER TWP MUN AUTH WELL\#26 } & 17.400 \\ 101237 \text { WARMINSTER TWP MUN AUTH WELL\#36 } & 5.400 \\ 101237 \text { WARMINSTER TWP MUN AUTH WELL\#37 } & 15.000 \\ 101237 \text { WARMINSTER TWP MUN AUTH WELL\#39 } & 6.060 \\ \text { *** Totals *** } & \\ \end{array}$

Allocation for Warminster Subbasin Little Neshaminy Watershed Most Recent DATA Allocations are for a 30 DAY Period

Page No. 1

$01 / 19 / 95$

\begin{tabular}{|c|c|c|}
\hline Water User & $\begin{array}{l}\text { Year } \\
\text { of } \\
\text { Data }\end{array}$ & Allocation \\
\hline 101237 WARMINSTER TWP MUNIC AUTH WELL 23A & 90 & 17.400 \\
\hline 101237 WARMINSTER TWP MUNIC AUTH WELL 23B & 90 & 8.600 \\
\hline 101237 WARMINSTER TWP MUN AUTH WELL \#24 & 90 & 10.000 \\
\hline *** Totals *** & & 36.000 \\
\hline
\end{tabular}

Comparison of Allocations with Ground Water Base-Flow Contribution with Warminster Subbasin Little Neshaminy Watershed Ground Water Contribution to Base-Flow for the 10-Year Recurrence Interval

Basin Contribution (mgal) Total Allocation (mgal) Difference (mgal) $2464.832-\quad 2317.142=\quad 147.691$

Comparison of Allocations with Total Ground Water/Surface Water Withdrawals for Warminster Subbasin Little Neshaminy Watershed

Total Withdrawals (mgal) Total Allocation (mgal) Difference (mgal) 1328.838 -

$2317.142=$

$-988.303$ 